IZA DP No. 9971

Coerced Labor in the Cotton Sector:

How Global Commodity Prices (Don't)

Transmit to the Poor

Alexander M. Danzer

Robert Grundke

May 2016 


\title{
Coerced Labor in the Cotton Sector: How Global Commodity Prices (Don't) Transmit to the Poor
}

\author{
Alexander M. Danzer \\ Catholic University of Eichstätt-Ingolstadt, WFI, \\ IOS Regensburg, IZA and CESifo \\ Robert Grundke \\ LMU Munich and IOS Regensburg
}

Discussion Paper No. 9971

May 2016

IZA

P.O. Box 7240

53072 Bonn

Germany

Phone: +49-228-3894-0
Fax: +49-228-3894-180
E-mail: iza@iza.org

Any opinions expressed here are those of the author(s) and not those of IZA. Research published in this series may include views on policy, but the institute itself takes no institutional policy positions. The IZA research network is committed to the IZA Guiding Principles of Research Integrity.

The Institute for the Study of Labor (IZA) in Bonn is a local and virtual international research center and a place of communication between science, politics and business. IZA is an independent nonprofit organization supported by Deutsche Post Foundation. The center is associated with the University of Bonn and offers a stimulating research environment through its international network, workshops and conferences, data service, project support, research visits and doctoral program. IZA engages in (i) original and internationally competitive research in all fields of labor economics, (ii) development of policy concepts, and (iii) dissemination of research results and concepts to the interested public.

IZA Discussion Papers often represent preliminary work and are circulated to encourage discussion. Citation of such a paper should account for its provisional character. A revised version may be available directly from the author. 


\section{ABSTRACT \\ Coerced Labor in the Cotton Sector: How Global Commodity Prices (Don't) Transmit to the Poor}

This paper investigates the economic fortunes of coerced vs. free workers in a global supply chain. To identify the differential treatment of otherwise similar workers we resort to a unique exogenous labor demand shock that affects wages in voluntary and involuntary labor relations differently. We identify the wage pass-through by capitalizing on Tajikistan's geographic variation in the suitability for cotton production combined with a surge in the world market price of cotton in 2010/11 in two types of firms: randomly privatized small farms and not yet privatized parastatal farms, the latter of which command political capital to coerce workers. The expansion in land attributed to cotton production led to increases in labor demand and wages for cotton pickers; however, the price hike benefits only workers on entrepreneurial private farms, whereas coerced workers of parastatal enterprises miss out. The results provide evidence for the political economy of labor coercion and for the dependence of the economic lives of many poor on the competitive structure of local labor markets.

JEL Classification: J47, J43, F16, O13, Q12

Keywords: coerced labor, export price, price pass-through, cotton, wage, local labor market, Tajikistan

Corresponding author:

Alexander M. Danzer

Department of Business Administration and Economics

KU Eichstätt-Ingolstadt

Auf der Schanz 49

85049 Ingolstadt

Germany

E-mail: alexander.danzer@ku.de 


\section{Introduction}

Free choice is among the fundamentals of economics. Yet, an estimated 46 million workers are subject to slavery and labor coercion globally (Global Slavery Index 2016). They are deprived of the freedom to choose their work and are exposed to (the threat of) violence. Workers in developing countries appear especially vulnerable to labor coercion: They toil in volatile and labor-intensive economic sectors such as cotton, garment, mining or staple food for little pay and under harsh working conditions. This particular part of the labor market has been largely neglected in economic research to date and we know little about the detrimental economic and social consequences of labor coercion for individual workers.

In this paper, we offer first empirical insights on this pressing problem. We shed light on the wage setting process of coerced workers in an open economy and investigate how short-run price fluctuations affect the lives of the poor at the bottom of a global supply chain. We exploit an exogenous rise in the world market price for cotton and the subsequent expansion in labor demand for cotton pickers to shed light on the wage effect for coerced vs. free workers in Tajikistan. Our contribution is threefold: First, we add to the scarce empirical literature on labor coercion (for theory see Acemoglu and Wolitzky 2011). A number of recent historical studies have emphasized the welfare reducing and inequality increasing longrun effect of labor coercion and slavery (Dell 2010; Acemoglu et al. 2012; Naritomi et al. 2012; Naidu and Yuchtmann 2013; Bobonis and Morrow 2014; Dippel et al. 2015). Yet, research on contemporary labor coercion is missing. Our empirical case study is unique in that we observe the coexistence of identical jobs (cotton picking) performed by either coerced or free workers, depending on rather exogenous local labor market conditions. This allows us to shed light on the differential treatment of highly comparable workers with some direct evidence on the politics of labor coercion. Given that coerced workers in our specific set-up have few viable outside options (e.g., students or civil servants) we can disentangle the pure labor demand effect on the wages of cotton pickers.

Second, our focus on cotton adds to the few studies analysing openness and poverty in agriculture, the economic sector which has received little attention in international economics despite providing the major source of income for three quarters of the world's poorest (Winters et al. 2004). While the welfare enhancing effect of trade is among the fundamentals of economics, the evidence on how openness immediately affects the poor is scarce. Recent research suggests that trade openness, trade liberalization and price fluctuations have strong 
distributional consequences ${ }^{1}$. Rising commodity prices seem to favor poor farmers in the long-run, yet the actual channels are not exactly clear (Heady 2014)—not least because the micro-level evidence regarding agriculture and local labor markets is scarce (Goldberg and Pavcnik 2007). Notable exceptions are the studies of the impact of rice price fluctuations on child labor and household labor supply in Vietnam by Edmonds and Pavcnik (2005; 2006). While studies on staple food face the complication of farmers being joint producers and consumers of the exported commodity, we can capture welfare effects directly since fluctuating prices in non-food agriculture have unambiguous effects on poor producers (Barrett and Dorosh 1996; Swinnen and Squicciarini 2012). ${ }^{2}$

Third, to compare the treatment of coerced vs. free workers with respect to employment and wages, we exploit an exogenous change in the world market price of cotton together with geographic variation in the suitability of agricultural land for cotton production. Hence, our research adds to the literature employing price variation and regional differences in the production structure of countries to identify exogenous labor demand shocks (Acemoglu et al. 2013; Angrist and Kugler 2008; Black et al. 2005; Chiqiar 2008; Kovak 2013; Topalova 2010). Unlike ours, none of the aforementioned papers focuses on low income countries which suffer from especially narrow economic export structures that make them disproportionately vulnerable to commodity price fluctuations (Massell 1964; Jacks, O'Rourke and Williamson 2011). At the same time, we address the recently emerging empirical literature that exploits exogenous labor demand shocks to investigate local labor markets (Autor, Dorn and Hanson 2013; Kaur 2014; Greenstone and Moretti 2003; 2011).

The history of price hikes in the global cotton market goes back to the American Civil War and has experienced several ups and downs since then (Deaton 1999). The latest cotton price surge took place during the 2010/2011 season, when China (the largest cotton producer and consumer) had to double its cotton imports after a severe crop failure in several countries. Our paper exploits this last price episode to investigate the following questions: How do market fluctuations for an internationally traded commodity (cotton) affect the weakest link of

\footnotetext{
${ }^{1}$ A growing literature has analysed the wage effects of openness, especially with respect to shifts in skill requirements. In manufacturing (on which most research focusses) trade liberalization has prompted ambiguous wage effects across skill groups (Wood 1997; Attanasio, Goldberg and Pavcnik 2004), production stages (Costinot, Vogel and Wang 2012) and gender (Juhn, Ujhelyi and Villegas-Sánchez 2013). Recent papers have investigated the effect of trade liberalization on local labor markets (Kovak 2013) and the role of exporting firms. Firms have been thought to contribute to wage inequality either through export premiums (Krishna, Poole and Zeynep Senes 2012) or through heterogeneous wage setting mechanisms (Amiti and Davis 2011).

${ }^{2}$ While previous studies have focused on price changes due to trade liberalization, world market prices in agriculture have become increasingly volatile owing to weather shocks and misguided trade policies (Ivanic and Martin 2008; Anderson et al. 2013).
} 
the global production chain in the garment and textile industry: the cotton pickers? How does labor coercion affect the wage pass-through of world market price fluctuations? We will particularly focus on the heterogeneity between private and parastatal cotton farms: Randomly privatized small farms tend to act entrepreneurial and hire cotton pickers in local labor markets which are characterized by upward sloping supply curves. Quite differently, large parastatal or state-owned farms are controlled by local political elites and face perfectly elastic labor supply; they rely on political connections to coerce members of the collective as well as other workers such as civil servants, students and pupils during harvest time.

We answer our research questions empirically based on new nationally-representative longitudinal household and labor force data from Tajikistan, a small global cotton producer whose economy is fully dependent on cotton exports. The difference-in-differences approach exploits regional variation in the suitability of land for cotton production alongside exogenous variation in labor demand over time: The 2010/2011 world market price surge for cotton implied an exogenously induced production expansion by almost 40 percent in Tajikistanstimulating the demand for labor during harvest time significantly. To differentiate between wage effects for coerced vs. free workers, we analyze the subsamples of large and small farms separately.

Our results indicate that the cotton world price hike led to an expansion of employment in the cotton sector at the extensive margin. Cotton workers benefitted in financial terms while agricultural non-cotton workers experienced no wage gains. In line with the predominant employment of women in cotton picking, the wages of female laborers increased strongly due to higher world market prices. The positive development of hourly wages exceeds that of monthly earnings, suggesting an intra-marginal adjustment in working hours. Hence, the income effect dominates the substitution effect at the household level-in line with previous evidence for agricultural crops in other developing countries (Jayachandran 2006). The positive pass-through from prices to wages is, however, concentrated among workers on private farms, while large parastatal farms do not offer higher wages in the period of high labor demand. This result is fully in line with qualitative and quantitative evidence from Tajikistan that parastatal farms exploit their political connections to coerce local workers into a perfectly elastic labor pool. It also aligns with our empirical findings of surging child labor rates in cotton areas. At the same time, managers of both farm types earn substantially more as a consequence of higher product prices; however, the gains are disproportionately higher for managers of large parastatal farms who appropriate the benefits from higher 
revenues alone. The results of several falsification exercises corroborate our findings that private farms act more market oriented in attracting harvest workers while large parastatal farms rely on political capital and labor coercion.

The remainder of the paper is structured as follows: Section 2 describes the market structure of the cotton sector in Tajikistan and the exogenous cotton price shock. It also derives theoretical predictions regarding employment and wages of cotton pickers on small private and large parastatal cotton farms. Section 3 describes the data and empirical strategy. Section 4 presents and discusses our main results and several robustness checks. Section 5 concludes.

\section{Background}

Tajikistan is a landlocked lower income country in Central Asia, neighboring Afghanistan, China, Kyrgyzstan and Uzbekistan. In 2011, it ranked 150 out of 185 in terms of GDP per capita PPP according to the IMF. Hence, Tajikistan's GDP per capita PPP is less than one fourth of China's. Tajikistan has 7.6 million inhabitants. Around 67 percent of its working population is employed in agriculture, the least paying sector of the economy (van Atta 2009). This share comes close to 100 percent in rural areas, where the economically active population consists mainly of women due to large-scale male labor emigration (Danzer and Ivaschenko 2010). Most of Tajikistan's territory is mountainous, making cotton production only feasible in some climatically and geographically sharply defined areas below $1000 \mathrm{~m}$ altitude. Cotton is grown on $29 \%$ of the total cultivated area (2007), with other important crops being wheat, fruits and vegetables - the latter predominantly for the domestic market (FAO 2009; TajStat 2012). While farmers can switch cultivation between cotton and wheat on a yearly basis, land plots for food production normally remain for personal use.

\subsection{The cotton sector in Tajikistan}

All of Tajikistan's cotton is exported, thus generating around 30 percent of export revenues per annum. ${ }^{3}$ At the same time the country remains a small producer with only $1 \%$ of the global annual cotton production (FAO 2011). Much of today's production structure with

\footnotetext{
${ }^{3}$ The domestic freight traffic is operated by small private firms in a competitive environment (based on mediumsized trucks) (WFP 2005). Tajikistan is landlocked and its integration in international transport systems is inefficient due to a lack of investment. In the early 2000s, more than 80 percent of exports were exported by Tajik Railways through Uzbekistan which controls export routes and charges high tariffs (WFP 2005).
} 
its interdependent 'contract farming' relationships between futurists ${ }^{4}$, farm managers, politicians and hired or coerced agricultural laborers is a remnant from Soviet times, although this type of quasi-command agriculture is common to the cotton sector in many poor countries (van Atta 2009; Brambilla and Porto 2011; Kranton and Swamy 2008). During the Soviet era the cotton industry comprised large state-owned farms (kolkhozes and sovkhozes) which recruited agricultural laborers during harvest time. Coerced labor of students, state employees and children was widespread (ILRF 2007).

In 1996, the Tajik government officially initiated the privatization of cultivated farmlands by handing out inheritable land use rights; note, that all land has remained in state ownership. By 2007, the central government had officially turned 53 percent of the designated area into private usership. After 2009, the privatization process of the State Committee for Land and Geodesy (SCLG) came to a halt in the sense that almost no additional land was transferred from state owned farms into private usership (Lerman 2012; Fig. A4). The privatization process resulted in the creation of private dehkan farms which command between 2 and 20 ha of farmland with well-defined and inheritable land usage rights. ${ }^{5}$ They emanated from several privatization programs after international donors and the World Bank had pressurized the government to give up its influence on farmers' planting decisions and to increase the market orientation of agricultural production (Sattar and Mohib 2006; World Bank 2012). ${ }^{6}$ Private farms predominantly grow cotton, wheat and vegetables and account for $40 \%$ of Tajikistan's total cotton production (FAO 2009).

The un-restructured part of agriculture comprises large (parastatal or state-owned) farms (more than 20 hectares of land and/or 25 workers, often many more). Strong reciprocal relationships exist between farm managers and local/regional politicians. In most districts, parastatal and state-owned farms support social services like hospitals, schools and

\footnotetext{
${ }^{4}$ Futurists are intermediate cotton traders that pre-finance cotton production by supplying in-kind inputs to farmers and by taking the future cotton harvest as collateral. (Sattar and Mohib, 2006, van Atta 2009).

${ }^{5}$ In addition to proper privatization, about one third of farm land allocated to dehkan farms was officially privatized but not restructured (FAO 2009, 2011; Tab. A1). Such parastatal collective farms are bigger than the properly privatized dehkan farms and are in most cases led by farm managers from Soviet times (who have been appointed for lifetime) with little or no changes in decision making rules and incentive structures. Against this background, we treat these farms like un-privatized farms. Individual farmers of parastatal collective farms may in theory opt out of the collective using their respective land shares. However, individual land use rights do not exist on collective farms. The State Committee for Land and Geodesy (SCLG) issues a land use certificate in the name of the farm manager which only lists all names of members of the collective but does not define land plots for each member. Hence, opting out is not a realistic choice (van Atta 2009, Interviews Appendix D). Further barriers include credit constraints, social norms and political pressure (Sattar and Mohib 2006, van Atta 2009).

${ }^{6}$ The representative Farm Privatization Support Project (FPSP), for instance, split up large state owned farms (of $17000 \mathrm{ha}$ ). Equal per-capita acreage (on average about $0.6 \mathrm{ha}$ ) was distributed to all members by a lottery and personal land use certificates valid for 99 years were allocated to all individuals (Sattar and Mohib 2006). Families pooled their land shares to establish family dehkan farms (Sattar and Mohib 2006, World Bank 2012).
} 
kindergartens, just as during Soviet times. While these social services have been officially transferred to local authorities during transition, most of them have not received sufficient financial means to run them (Sattar and Mohib 2006, Kassam 2011). As a result, large farms provide financial resources or in-kind services in exchange for support of their cotton harvesting activities. Local governments offer assistance by coercing state employees, students and school children into cotton picking (van Atta 2009, ILRF 2007, see also qualitative evidence from the interviews in Appendix D). ${ }^{7}$

In sum, the cotton growing sector in Tajikistan comprises two farm types (private vs. parastatal/state farms) which use comparable production techniques and land of similar quality since land was distributed by lottery (Sattar and Mohib 2006). According to a survey among more than 4,200 farms in Tajikistan, there are no productivity differences between farm types, probably because cotton is extremely labor intensive without much scope for economies of scales and because infrastructure such as irrigation has depreciated since Soviet times (Table 1, World Bank 2012). ${ }^{8}$ The most labor intensive production step is manual harvesting for which farms require additional pickers. With a monthly pay of around 38 USD, cotton picking is among the worst paid economic activities in Tajikistan. ${ }^{9}$ Overall, the wage bill accounts for 10-15 percent of total production costs of farms (Sattar and Mohib 2006).

Cotton workers are exclusively drawn from the local rural labor market. This is due to the fact that women in rural Tajikistan are severely limited in their geographic action space: working outside the local community is considered culturally unacceptable. While private dehkan farms hire free workers at the local labor market, parastatals and state-owned farms exploit pseudo-feudal structures and family bonds: Managers not only command members of the collective but also all their extended local family members. Additionally, they rely on political connections to coerce cotton pickers and, hence, gain access to an unlimited pool of

\footnotetext{
${ }^{7}$ Strong interdependent and reciprocal relationships between local politicians and agricultural firms are also reported for other developing countries (Sukhtankar 2012).

${ }^{8}$ Changes in productivity which are typical for post-privatization periods (Pavnik 2002) will not influence our estimates of the price shock which took place several years later. Additional data collected in Tajikistan also shows that there are no productivity differences between small private firms and large parastatal enterprises (Appendix B, TajStat 2012).

${ }^{9}$ Notably, there is a minimum pay for cotton pickers which is set by regional authorities in the harvest season. Occasionally, cotton pickers also receive in-kind payment in the form of cotton stalks, which they use for heating (van Atta 2009). Including wages in-kind in the dependent variable does not change our results (Tab. A13).
} 
workers from other (state-owned) enterprises, universities and schools (ICG 2005, ICLG 2007; van Atta 2009; Department of State 2010). ${ }^{10}$

Table 1: Farm Characteristics from the GIZ 2013 farm survey

\begin{tabular}{|c|c|c|c|c|}
\hline & \multicolumn{2}{|c|}{ Group Means } & \multirow[t]{2}{*}{$\begin{array}{c}\text { Difference } \\
\text { (Large-Small) }\end{array}$} & \multirow{2}{*}{$\begin{array}{l}\text { p-value of the two- } \\
\text { sided T-Test }\end{array}$} \\
\hline & $\begin{array}{l}\text { Small Farms } \\
\quad(<20 \text { ha })\end{array}$ & $\begin{array}{c}\text { Large } \\
\text { Farms } \\
(\mathbf{2 0 +} \text { ha) }\end{array}$ & & \\
\hline \multirow{2}{*}{ Worker per ha under cotton } & 2.418 & 2.439 & 0.021 & 0.840 \\
\hline & $(0.055)$ & $(0.093)$ & $(0.021)$ & \\
\hline \multirow{2}{*}{$\begin{array}{l}\text { Female worker per ha under } \\
\text { cotton }\end{array}$} & 1.438 & 1.531 & 0.094 & 0.195 \\
\hline & $(0.033)$ & $(0.064)$ & $(0.072)$ & \\
\hline \multirow[t]{2}{*}{$\begin{array}{l}\% \text { of farm area cropped with } \\
\text { cotton (in 2013) }\end{array}$} & 0.470 & 0.511 & 0.041 & 0.008 \\
\hline & $(0.009)$ & $(0.013)$ & $(0.015)$ & \\
\hline \multirow{2}{*}{$\begin{array}{l}\text { Cotton yield in } 100 \mathrm{~kg} \text { per ha (in } \\
\text { 2011) }\end{array}$} & 23.320 & 23.620 & 0.301 & 0.250 \\
\hline & $(0.120)$ & $(0.232)$ & $(0.261)$ & \\
\hline Number of observations & 3384 & 869 & & \\
\hline
\end{tabular}

Source: GIZ Survey of farms 2013

In the agricultural season 2010/2011 the world market for cotton was disturbed by floods and droughts in the major cotton producing countries China, India and Pakistan: Within a year, China - the global leader in cotton production and consumption-more than doubled its cotton imports from 12 to almost 25 million $480 \mathrm{lb}$. bales of cotton (according to the United States Department of Agriculture); this led to a more than doubling of the world cotton price between July 2010 and March 2011 (Fig. 1). ${ }^{11}$

\footnotetext{
${ }^{10}$ In line with findings in Naidu and Yuchtman (2013), managers of parastatals and state-owned farms might also use their political connections to prevent the members of the collective to join harvesting activities at potentially better paying small private farms.

${ }^{11}$ The price of wheat remained roughly constant (Fig. A2).
} 


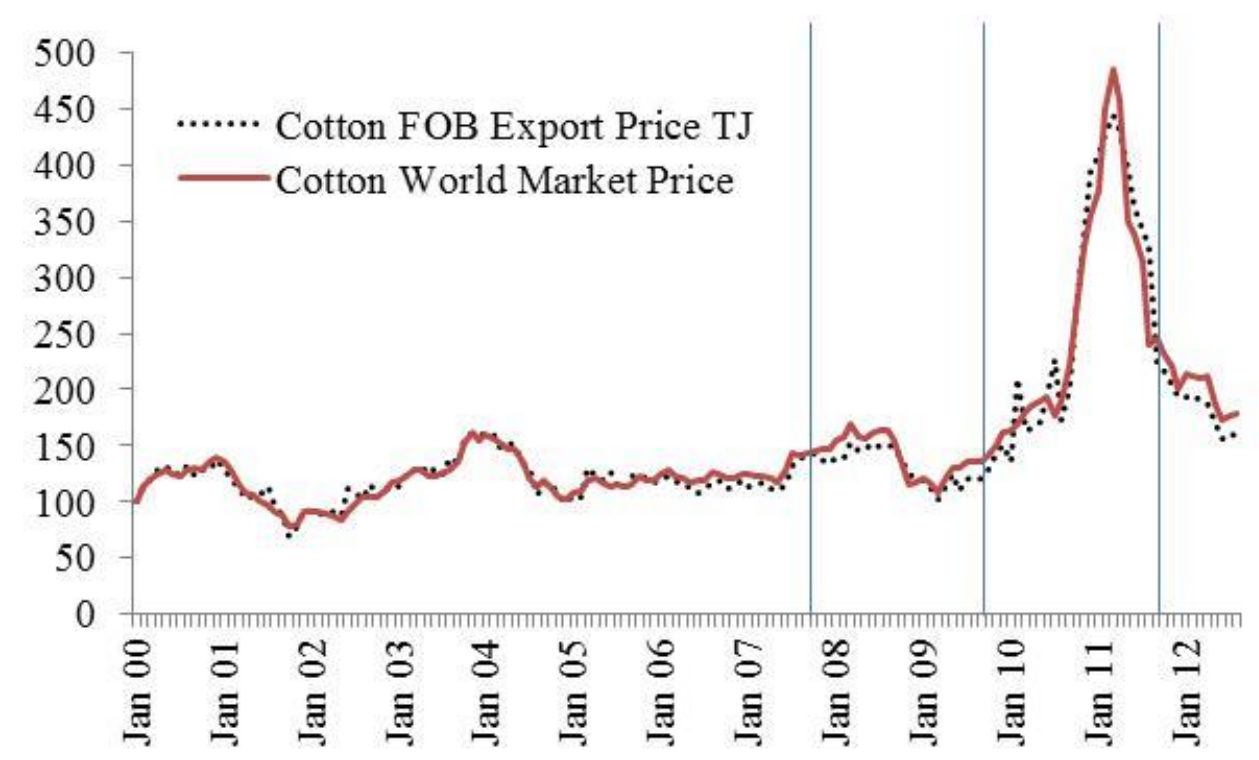

Fig. 1: Cotton world market price $(100=2000)$

Note: The vertical lines mark survey dates. Source: IMF Primary Commodity Prices (Cotton Outlook 'A Index', Middling 1-3/32 inch staple, CIF Liverpool, US cents per pound) and Statistical Agency of Tajikistan.

Since prices were substantially higher in the sowing period 2011, many farmers expanded the area devoted to cotton. ${ }^{12}$ It is important to note that the vast majority of farmers (even small private ones) regularly observe the cotton world market price, according to the GIZ farmer survey 2011 (Tab. A2). The area harvested with cotton (other crops) increased (decreased) substantially (FAO 2011, TajStat 2012). This led to an increase in cotton production in Tajikistan by almost 40 percent (Fig. A1), reversing the decade long declining trend that was owing to the country's lack in infrastructure/irrigation investments and the shift towards food production (Akramov and Shreedhar 2012). As a consequence the demand for cotton workers surged. Importantly, Fig. 2 shows that both farm types (small private and large parastatal) increased the area harvested with cotton as well as cotton production and, thus, faced an increase in labor demand for cotton pickers during the harvest time of $2011 .^{13}$

\footnotetext{
${ }^{12}$ Switching from other crops to cotton is easily feasible at the beginning of the agricultural season.

${ }^{13}$ Fig. A3 in the Appendix shows that this does not depend on how we define small and large farm districts. Additional data that we collected in Tajikistan (Appendix B) also show that small private and parastatal/stateowned farms increased the area cropped with cotton from 2009 to 2011 (FAO 2011, TajStat 2012).
} 


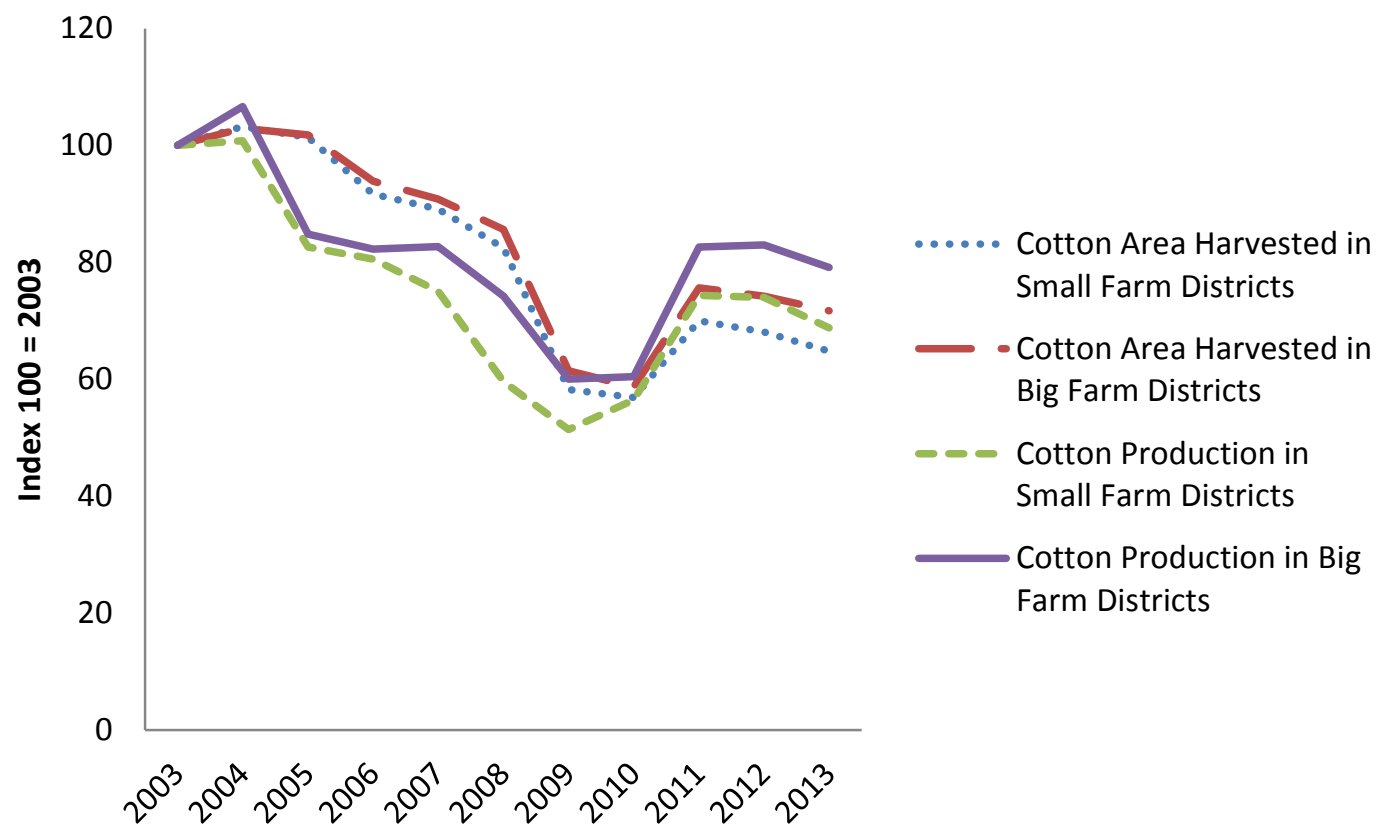

\section{Fig. 2: Cotton production and area harvested in small vs. large farm districts .}

Note: Data on cotton production and area harvested per district are from the FAO Crop Statistics for Tajikistan (Appendix B). Tajik districts are separated into small and large farm districts using information from the TLSS 2009. We define small (large) farm districts as districts which have a share of agricultural workers working on small farms higher (lower) than $50 \%$.

\subsection{Theoretical considerations: the wage pass-through in private vs. parastatal farms}

A simple model that captures the main features of the Tajik cotton sector can describe the differential pass-through of the world cotton price surge to wages of free vs. coerced cotton pickers (details in Appendix C). We assume that there are two representative farm types (small private vs. large parastatal) that produce cotton or wheat. ${ }^{14}$ Both farms command the same constant returns to scale Cobb-Douglas production technology using land and labor. ${ }^{15}$ The total land endowment per farm is fixed, because proper land markets do not exist in Tajikistan (van Atta 2009, Lerman 2012). Land is allocated between cotton and wheat production (Shumway et al. 1984). The production factor labor is mobile between cotton and wheat within the farm, whereby cotton is more labor intensive than wheat. Both farm types are (farm gate) price takers for raw cotton. They sell to the monopsonistic local gin which exports ginned cotton at the FOB export price-equal to the spot rate for cotton at the

\footnotetext{
${ }^{14}$ Wheat is the main alternative crop grown by farms in cotton regions of Tajikistan (FAO 2009, 2011). In the model, we could also interpret wheat as an aggregate of alternative crops.

${ }^{15}$ For simplicity we exclude other inputs like seeds or fertilizer. However, including these additional inputs does not change the results of the comparative statics.
} 
Liverpool Stock Exchange minus transportation costs (Kassam 2011). Wheat is exclusively supplied to the domestic market, whereby both farm types are also price takers.

Farms maximize profits by allocating optimal shares of land and labor to wheat vs. cotton at given production technologies, output prices and interest rates. It is straightforward to show that in response to a surging cotton export price the gin maximizes profits by increasing the farm gate price in order to stimulate cotton supply (Appendix C). Rising cotton prices induce farmers to dedicate more land to cotton production, as happened in Tajikistan in 2011 (FAO 2011). Since cotton is more labor intensive than wheat both farm types expand their labor demand for harvest workers. ${ }^{16}$

The pivotal difference between farms is that small private dehkan farms compete for cotton pickers on the local labor market, while large parastatal farms which are heavily intertwined with local politicians receive harvest workers sent by the local government. These workers (e.g. public employees of public administration, schools, hospitals as well as students and school children) are coerced into cotton harvesting for minimum wages that are announced by district authorities for each harvest season. Technically, private dehkan farms face an upward sloping labor supply curve while parastatal/state-owned farms face a perfectly elastic labor supply curve. Fig. 3 illustrates the wage implications of these differences in labor supply: workers on small farms will enjoy higher wages, while coerced laborers on parastatals gain nothing. Since most cotton pickers are female, we expect all worker effects to be concentrated among women. At the same time, managers of parastatal/state-owned farms are expected to appropriate the withheld profits.

\footnotetext{
${ }^{16}$ Fig. 2 and additionally collected data (Appendix B) show that small private and parastatal/state-owned farms increased the area cropped with cotton in 2011 (FAO 2011, TajStat 2012). Farm managers of large and small farms closely follow the world prices of cotton (Tab. A2) and base their growing decisions in early spring on this information.
} 


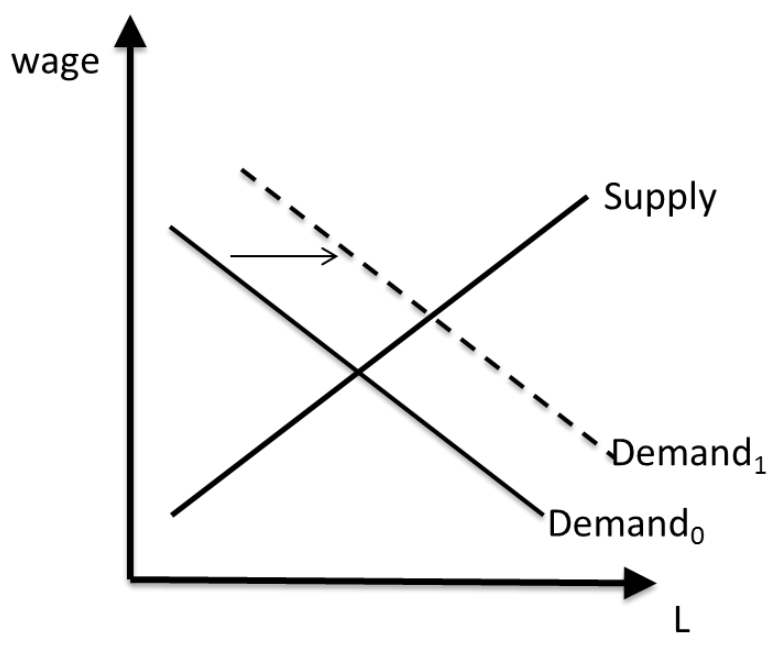

Labor supply for small family farms

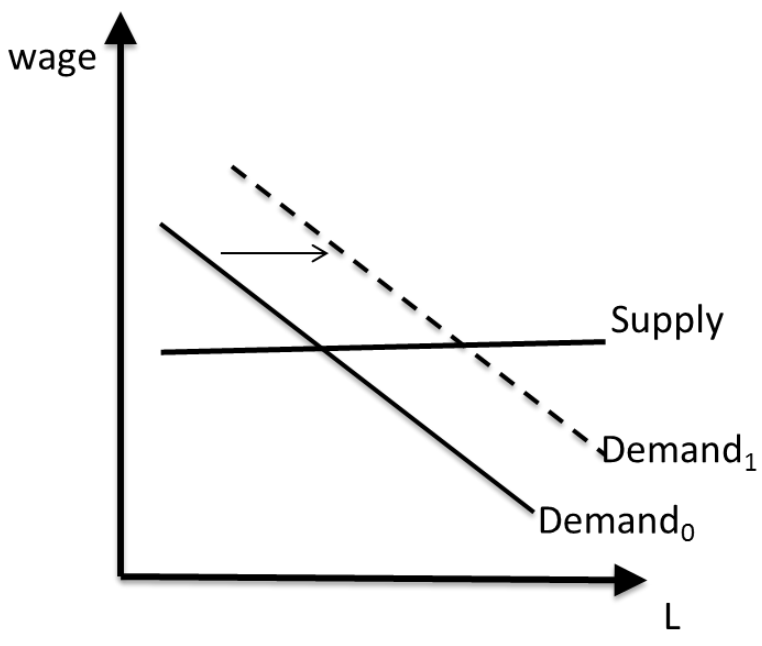

Labor supply for big parastatals

\section{Fig. 3: Labor market equilibrium for small private vs. large parastatal farms}

The figure shows the stylized comparative statics in response to a surge in the world cotton price.

\section{Data and empirical approach}

Our empirical analysis builds on the Tajikistan Living Standard Survey (TLSS) conducted by the World Bank and UNICEF in 2007 and 2009 and a follow up survey in 2011 conducted by the Institute for East and Southeast European Studies (IOS). All three waves of this panel were collected during the cotton harvest season providing comparable measures of labor market participation. The first wave in 2007 comprises a representative sample of 4,860 households living in 270 primary sampling units (PSUs). In the second and third wave, the sample consists of a representative sub-set of 167 PSUs and 1,503 households (Danzer, Dietz and Gatskova 2013). For comparability, we restrict the sample to households living in the 167 PSUs that are included across all three waves. ${ }^{17}$ The survey contains a wide range of household and individual level characteristics. Our estimation sample includes the working age population for Tajikistan as defined by the World Bank: males older than 14 and younger than 63 and females older than 14 and younger than 58. The number of individual-year spells is 23,398 .

\footnotetext{
${ }^{17}$ As a robustness check, we run regressions including the households living in the 103 PSUs excluded after 2007 and our results do not change. We also run regressions excluding the households that only appear in 2007 and our results do not change. The results of these robustness checks are available on requested.
} 


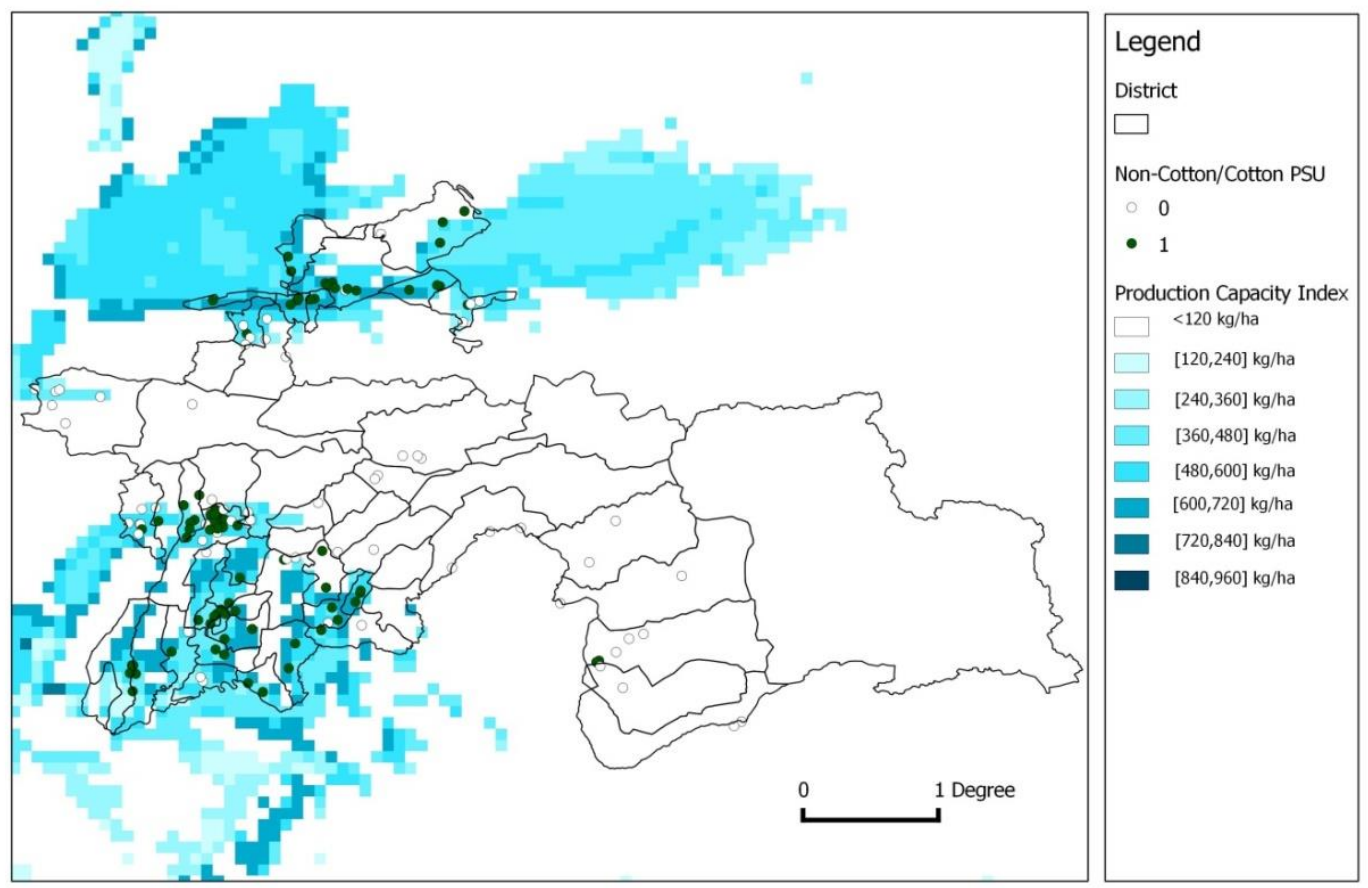

Fig. 4: Regional variation of cotton production in Tajikistan (cotton/non-cotton communities in the TLSS 2007)

Note: Cotton/non-cotton communities (PSUs) from TLSS 2007 (in black/white), cotton communities are communities that grow cotton as first or second most important crop. FAO - GAEZ - Production capacity index for cotton (for current cultivated land and intermediate input level irrigated cotton). Administrative units are districts (hukumats); there are 58 districts in Tajikistan.

Identification of wage effects of the 2011 international cotton price surge stems from time variation in the global cotton price and from geographic variation in the suitability of agricultural land for cotton production. Price fluctuations are approximated by year dummies with the 2011 dummy reflecting the high-price episode. We generate the indicator for cotton regions based on crop information at the primary sampling units (PSUs/communities) in the 2007 community survey (conducted alongside the TLSS). PSUs in which cotton was reported as the first or second most important crop, are defined as cotton PSUs. Non-cotton PSUs are all remaining predominantly agricultural PSUs (see Fig. 4 and Tab. A3 and A4 in the Appendix). ${ }^{18,19}$ Workers employed in agriculture in cotton (non-cotton) PSUs comprise the treatment (control) group (see Tab. A6 for summary statistics). ${ }^{20}$

${ }^{18}$ As robustness check, we use two additional definitions for cotton PSUs using external GIS data from the FAO GAEZ data base (FAO 2013) as well as using altitudes below 1000m sea level. The GIS data employ different criteria for soil quality, climate and other geographic characteristics to determine the suitability of arable land for cotton production (for details of these definitions see Appendix B). We merge the GIS data with the geo- 
Initially, we test whether the cotton price hike affected picking wages in general, by estimating the following OLS model for the pooled sample of free and coerced workers:

$\ln (\text { realwageph })_{\text {it }}$

$$
\begin{aligned}
& =\alpha+\beta_{1}\left(\text { cottonPSU } \times \text { year09) }+\beta_{2}(\text { cottonPSU } \times \text { year } 11)+\beta_{3}\right. \text { cottonPSU } \\
& +\beta_{4} \text { year09 }+\beta_{5} \text { year } 11+\beta_{6}(\text { agri } \times \text { year09 })+\beta_{7}(\text { agri } \times \text { year } 11) \\
& +\beta_{8}(\text { agri } \times \text { cottonPSU })+\beta_{9} \text { agri }+\beta_{10}(\text { cottonPSU } \times \text { year09 } \times \text { agri }) \\
& +\beta_{11}(\text { cottonPSU } \times \text { year } 11 \times \text { agri })+X_{i t}{ }^{\prime} \gamma+\tau+\delta+\theta+u_{i t}
\end{aligned}
$$

The dependent variable is the contemporary log real net hourly wage for individual $i$ in year $t .^{21}$ As regional CPIs are unavailable, we deflate wages by national CPI and control for province-year dummies in the model. We interact the year dummy 2011 with a dummy for cotton PSUs to capture the effect of the rising cotton price on cotton producing areas. The coefficient $\beta_{1}$ tests whether the wage growth between cotton producing and other areas differed already in the pre-price hike period from 2007 to 2009. In addition, the dummies for the years 2009 and 2011 and the cotton PSU dummy are included separately. The treatment effect is captured by $\beta_{11}$, which reports the effect of the cotton price shock on agricultural workers (agri) in cotton PSUs compared to agricultural workers in non-cotton PSUs. The coefficient $\beta_{10}$ tests whether there was a differential effect on agricultural wages in cotton PSUs compared to non-cotton PSUs in the pre-shock period. The vector of control variables $X$ includes gender, age, two dummies for middle and higher education (secondary educ. and tertiary educ.), three dummy variables for occupational group (occ. high stands for one-digit occupational codes 1-3, occ. middle stands for one-digit occupational codes 4, 5, 7 and 8, occ. skilled agric. stands for skilled agricultural occupations), a dummy for firm size indicating whether a firm has more than 50 employees (large firm), and a dummy for state owned enterprises (state firm). In addition, we include district fixed effects $\tau$ that control for all time invariant district specific characteristics, e.g. institutional characteristics that differ between

referenced PSUs in the TLSS 2007 survey. As additional robustness check, we define treatment at the district level, whereby any PSU in a cotton district is defined as cotton PSU. We classify a district as a cotton district, when more than a certain percentage of PSUs in that district are defined as cotton PSUs. As thresholds we use 30,50 , or 70 percent. Our results are preserved with these alternative definitions.

${ }^{19}$ Cotton PSUs are characterized by lower altitude, better connectivity to federal or district capitals and by better infrastructure (roads, irrigation) than non-cotton PSUs while population size and school enrolment do not differ significantly (Tab. A5). In robustness checks, we control for these community level variables as well as control variables at the sub-district level for the year 2007 and our results do not change.

${ }^{20}$ Note that we have no particular information regarding the actual crops workers are harvesting.

${ }^{21}$ In the survey, the variable wage is reported for the past month and hours worked for the last two weeks. As cotton pickers are paid daily wages, we use this information to compute the average hourly wage for the last month. Other information on labor market participation is measured for the last two weeks. However, in-kind wages are reported for the last year. As a robustness check, we rerun our analysis including average monthly inkind wages and the results do not change. 
districts. $^{22}$ The aforementioned province-year dummies $\theta$ control for time varying characteristics at the province level like economic activity, institutional changes and differing weather conditions. We also control for dummies of the interview month $\delta$ to capture time effects in the harvest season. ${ }^{23}$ In addition to the OLS estimation, we estimate each specification with individual fixed effects to control for unobserved heterogeneity at the individual level. ${ }^{24}$ Standard errors are clustered at the PSU/community level.

Our main interest is on differential wage effects on coerced vs. free workers. In the absence of direct evidence on labor coercion we refine our treatment group by distinguishing between wage effects within small private vs. large parastatal/state-owned farms (see Tab. A7 for summary statistics). As the TLSS data do not include information on the area cultivated by farms, we use employment size as defining criterion. Our qualitative interviews with farmers and officials in Tajikistan as well as World Bank (2012) suggest that size (more than 20 ha of land and/or 25 employees) is the most reliable criterion to identify parastatal or state-owned farms. Building on the exogenous heterogeneity between farm types, we run regressions akin to (1) for separate subsamples of small ( $\leq 25$ employees) vs. large firms (>25 employees). ${ }^{25}$ Note, that our approach to define labor coercion using farm size rather than survey responses circumvents two sources of endogeneity: first, the potential self-selection of firms into labor coercion and, second, the potential misreporting bias in survey questions on labor coercion.

\section{Results}

The world cotton price hike had profound consequences both for labor force participation as well as workers' incomes.

\subsection{Participation in cotton picking}

According to our theoretical considerations, high cotton prices during the sowing period of 2011 let many farmers shift their agricultural production from other crops (predominantly wheat) to cotton. This implies an expansion of agricultural area devoted to cotton and hence larger areas to be harvested in late 2011. Since the cotton harvest is much more labor-

\footnotetext{
${ }^{22}$ Tajikistan comprises 5 provinces (Oblasts), 58 districts (Hukumat) and 406 sub-districts (Jamoats).

${ }^{23}$ In robustness checks, we use dummies for two week periods. Our results are fully preserved.

${ }^{24} \mathrm{We}$ also present the results for the estimation of a simple Diff-in-Diff estimation for the sub-samples of agricultural and non-agricultural workers in the Appendix. Our results are fully preserved.

${ }^{25}$ As an alternative approach we enrich (1) by interactions with a dummy for working at a firm with at most 25 employees (small) yielding a quadruple diff. Since the results are very similar we prefer the specification with fewer restrictions on the covariates.
} 
intensive than the harvest of other crops, farmers have to adjust their workforce accordingly. Based on these considerations we have predicted a relative expansion of the agricultural workforce in cotton-growing areas. And indeed, unconditional employment rates expanded between 2009 and 2011 by 39.4 percent in smallholder districts and 37.6 percent in parastatal districts.

To analyze labor supply adjustments to the price shock in our panel, we employ linear probability specifications akin to equation (1) (but without the dummy for working in agriculture and all its interaction terms) with a dummy indicating work in agriculture as dependent variable. ${ }^{26}$ The estimation uses the full sample of working age adults.

Indeed, participation in the agricultural sector has substantially increased in areas which are suitable for cotton production (Tab. 2, col. 1-3): Compared to the base year, the probability that an individual of working age was working in agriculture in cotton areas went up by 11 percentage points in 2011. This effect was concentrated among women whose attachment to agricultural employment increased by 13 percentage points (or 68 percent). ${ }^{27}$ This is unsurprising as women form the vast majority of cotton pickers. These effects remain identical irrespective of whether we include individual fixed effects or whether we control for the district share of workers on small farms (in the total agricultural workforce) (Tab. A15, A19). The latter result suggests that the workforce expansion took place across all cotton areas, no matter whether they were predominantly characterized by smallholder or parastatal farming structures.

\footnotetext{
26 We exclude occupation dummies that are highly endogenous to the dependent variable 'working in agriculture'. We additionally control for individual, household, PSU and sub-district level characteristics in 2007 that may influence the labor supply decision. For robustness, we estimate the participation equation with the same control variables appearing in the wage regression and the results do not change (available upon request). The results of the wage regressions are also robust to including the additional controls at the individual, household, PSU and sub-district level (Tab. A21).

${ }^{27}$ Tab. A8 shows that 19 percent of working age females in cotton PSUs were working in agriculture in 2007.
} 
Table 2: Participation in Agriculture and hourly wage effects

\begin{tabular}{|c|c|c|c|c|c|c|}
\hline \multirow[b]{4}{*}{ Dependent variable } & $(1)$ & $(2)$ & (3) & (4) & (5) & (6) \\
\hline & \multicolumn{3}{|c|}{ Working age population } & \multicolumn{3}{|c|}{ Working population (employees) } \\
\hline & $\begin{array}{c}\text { Full } \\
\text { sample }\end{array}$ & Male & Female & $\begin{array}{c}\text { Full } \\
\text { sample }\end{array}$ & Male & Female \\
\hline & \multicolumn{3}{|c|}{ Working in agriculture } & \multicolumn{3}{|c|}{ Log of the real wage per hour } \\
\hline CottonPSU*year2009 & $\begin{array}{c}0.03 \\
(0.05)\end{array}$ & $\begin{array}{c}0.02 \\
(0.05)\end{array}$ & $\begin{array}{c}0.04 \\
(0.06)\end{array}$ & $\begin{array}{c}0.13 \\
(0.10)\end{array}$ & $\begin{array}{c}0.02 \\
(0.11)\end{array}$ & $\begin{array}{c}0.19 \\
(0.15)\end{array}$ \\
\hline CottonPSU*year2011 & $\begin{array}{c}0.11^{* *} \\
(0.05)\end{array}$ & $\begin{array}{c}0.09 \\
(0.05)\end{array}$ & $\begin{array}{c}0.13 * * \\
(0.06)\end{array}$ & $\begin{array}{l}-0.13 \\
(0.10)\end{array}$ & $\begin{array}{l}-0.14 \\
(0.10)\end{array}$ & $\begin{array}{l}-0.18 \\
(0.17)\end{array}$ \\
\hline CottonPSU*year2009*Agri & & & & $\begin{array}{l}-0.21 \\
(0.27)\end{array}$ & $\begin{array}{l}-0.26 \\
(0.32)\end{array}$ & $\begin{array}{l}-0.31 \\
(0.33)\end{array}$ \\
\hline CottonPSU*year2011*Agri & & & & $\begin{array}{c}0.34 \\
(0.22)\end{array}$ & $\begin{array}{c}0.05 \\
(0.25)\end{array}$ & $\begin{array}{c}0.62 * * \\
(0.26)\end{array}$ \\
\hline Female & $\begin{array}{l}-0.00 \\
(0.01)\end{array}$ & & & $\begin{array}{c}-0.35 * * * \\
(0.03)\end{array}$ & & \\
\hline Age & $\begin{array}{c}0.00 * * * \\
(0.00)\end{array}$ & $\begin{array}{c}0.00 * * * \\
(0.00)\end{array}$ & $\begin{array}{c}0.00 * * * \\
(0.00)\end{array}$ & $\begin{array}{c}0.00 \\
(0.00)\end{array}$ & $\begin{array}{l}-0.00 \\
(0.00)\end{array}$ & $\begin{array}{c}0.01 * * * \\
(0.00)\end{array}$ \\
\hline Secondary educ. & $\begin{array}{c}0.02 * * \\
(0.01)\end{array}$ & $\begin{array}{c}0.03 * * \\
(0.01)\end{array}$ & $\begin{array}{c}0.03 * * \\
(0.01)\end{array}$ & $\begin{array}{c}0.10 * * * \\
(0.04)\end{array}$ & $\begin{array}{c}0.16^{* * * *} \\
(0.05)\end{array}$ & $\begin{array}{c}0.02 \\
(0.05)\end{array}$ \\
\hline Tertiary educ. & $\begin{array}{c}-0.07 * * * \\
(0.01)\end{array}$ & $\begin{array}{c}-0.07 * * * \\
(0.02)\end{array}$ & $\begin{array}{c}-0.06 * * * \\
(0.02)\end{array}$ & $\begin{array}{c}0.35 * * * \\
(0.05)\end{array}$ & $\begin{array}{c}0.32 * * * \\
(0.06)\end{array}$ & $\begin{array}{c}0.43 * * * \\
(0.08)\end{array}$ \\
\hline Large firm & & & & $\begin{array}{c}0.05 \\
(0.04)\end{array}$ & $\begin{array}{c}0.13 * * * \\
(0.04)\end{array}$ & $\begin{array}{l}-0.07 \\
(0.06)\end{array}$ \\
\hline State firm & & & & $\begin{array}{c}-0.43 * * * \\
(0.04)\end{array}$ & $\begin{array}{c}-0.41 * * * \\
(0.05)\end{array}$ & $\begin{array}{c}-0.39 * * * \\
(0.06)\end{array}$ \\
\hline Occ. High & & & & $\begin{array}{c}0.15 * * * \\
(0.05)\end{array}$ & $\begin{array}{c}0.07 \\
(0.06)\end{array}$ & $\begin{array}{c}0.31 * * * \\
(0.10)\end{array}$ \\
\hline Occ. Middle & & & & $\begin{array}{c}0.23 * * * \\
(0.04)\end{array}$ & $\begin{array}{c}0.12 * * \\
(0.05)\end{array}$ & $\begin{array}{c}0.40 * * * \\
(0.10)\end{array}$ \\
\hline Occ. skilled agric. & & & & $\begin{array}{l}-0.11 \\
(0.07)\end{array}$ & $\begin{array}{c}-0.31 * * * \\
(0.09)\end{array}$ & $\begin{array}{c}0.07 \\
(0.11)\end{array}$ \\
\hline Constant & $\begin{array}{c}-0.74 * \\
(0.43)\end{array}$ & $\begin{array}{l}-0.66 \\
(0.52)\end{array}$ & $\begin{array}{c}-0.79 * \\
(0.46)\end{array}$ & $\begin{array}{c}0.17 \\
(0.11)\end{array}$ & $\begin{array}{c}0.09 \\
(0.14)\end{array}$ & $\begin{array}{l}-0.25 \\
(0.20)\end{array}$ \\
\hline Observations & 16,456 & 7,865 & 8,591 & 6,802 & 4,408 & 2,394 \\
\hline R-squared & 0.19 & 0.21 & 0.22 & 0.40 & 0.34 & 0.41 \\
\hline Adjusted R-squared & 0.182 & 0.199 & 0.208 & 0.394 & 0.328 & 0.390 \\
\hline $\begin{array}{l}\text { Note: In columns 1-3, the dependen } \\
\text { of the working age population (co } \\
\text { samples, respectively). In columns } \\
\text { estimated for all workers (column } \\
\text { respectively). All specifications are } \\
\text { the interview as well as dummies f } \\
\text { agriculture (agri) and its interactio } \\
\text { individual, PSU and sub-district lev } \\
\text { as household size. PSU level contro } \\
\text { location as well as measures for the } \\
\text { from the World Bank Socio-Econo } \\
\text { unemployment rate, the dependency } \\
\text { poverty line, the log of the popul } \\
\text { education, the share of households } \\
\text { Results for columns } 4-6 \text { do not cha } \\
\text { PSU level) in parentheses } * * * \text { p }<0 . \text {. }\end{array}$ & $\begin{array}{l}\text { is an indicato } \\
\text { fers to the fu } \\
\text { dependent va } \\
\text { the full sam } \\
\text { using OLS } \\
\text { SU and the } \\
\text { otton PSU a } \\
\text { ual controls } \\
\text { the year 200 } \\
\text { of Tajicult } \\
\text { share of the } \\
\text { ity, the shar } \\
\text { rical power } \\
\text { include thes }\end{array}$ & $\begin{array}{l}\text { vhether the pe } \\
\text { sample, where } \\
\text { ble is the log } \\
\text { whereas colt } \\
\text { include distri } \\
\text { r of the interv } \\
\text { the year dum } \\
\text { iprise dummie } \\
\text { ad include the } \\
\text { and male une } \\
\text { 2005) and ref } \\
\text { nomically act } \\
\text { plindividuals } \\
\text { ply in the dwe } \\
\text { dditional contr }\end{array}$ & $\begin{array}{l}\text { n works in a } \\
\text { column } 2 \text { a } \\
\text { al hourly w } \\
\text { n } 5 \text { and } 6 \text { sh } \\
\text { dummies, pr } \\
\text { w. Columns } \\
\text { ies. Column } \\
\text { or the ethnic } \\
\text { stance of the } \\
\text { loyment in t } \\
\text { either to the } \\
\text { (female) po } \\
\text { ith complete } \\
\text { ing as well a } \\
\text { variables (T. }\end{array}$ & $\begin{array}{l}3 \text { show resul } \\
\text { in the last } 1 \\
\text { results for th } \\
\text { nce-year dum } \\
\text { additionally } \\
3 \text { include ad } \\
\text { and the marit } \\
\text { U to the pro } \\
\text { PSU. Sub-dis } \\
\text { ar } 2003 \text { or th } \\
\text { tion, the sha } \\
\text { rimary educe } \\
\text { e share of h } \\
\text { A21). Robus }\end{array}$ & $\begin{array}{l}\text { lereby we us } \\
\text { or the male } \\
\text { th and the s } \\
\text { tale and fem } \\
\text { s, dummies } \\
\text { ude a dumm } \\
\text { onal control } \\
\text { tatus of the ir } \\
\text { e capital, a d } \\
\text { t level contro } \\
\text { ear } 2000 \text {. Th } \\
\text { f households } \\
\text {, with comp } \\
\text { holds with a } \\
\text { indard errors }\end{array}$ & $\begin{array}{l}\text { le full sample } \\
\text { female sub- } \\
\text { ifications are } \\
\text { sub-samples, } \\
\text { the month of } \\
\text { or working in } \\
\text { riables at the } \\
\text { vidual as well } \\
\text { imy for urban } \\
\text { ariables come } \\
\text { comprise the } \\
\text { ing below the } \\
\text { ed secondary } \\
\text { ndline phone. } \\
\text { ustered at the }\end{array}$ \\
\hline
\end{tabular}

\subsection{Effects on agricultural wages}

Before proceeding to the separate analysis of free vs. coerced workers, we first investigate whether cotton pickers benefitted from the global cotton price hike of 2011 at all 
(Tab. 2, col. 4-6). Female agricultural workers in cotton PSUs experienced significant hourly wage growth at the times of high cotton prices, hence, capitalizing on the improved conditions for producers in the global production chain. Estimating specification (1), we find that wage rates for women increased by highly significant $62 \mathrm{log}$ points (col. 6). The effect for male agricultural workers during the cotton price hike period is basically zero (col. 5), again reflecting the fact that cotton picking is dominated by women. Also note that there are no wage effects for the wave prior to the treatment year (2009) and for non-agricultural workers. This supports our identification strategy which crucially relies on the common trend assumption between cotton and non-cotton PSUs. Once we account for potentially confounding unobserved heterogeneity by including individual fixed effects, the wage effects from the cotton price hike become even more pronounced in size and significance (Tab. A15). This result is important as it refutes the possibility that our OLS estimates might suffer from composition effects: If newcomers in cotton-picking were significantly more productive than the previous workforce, the positive wage rates could merely reflect productivity effects; however, all qualitative evidence from our focus group discussions in Tajikistan suggests that farmers pay the same (hourly) wage rate to all pickers within the farm.

Importantly, we find comparable wage responses once we restrict our sample to agricultural workers in a simple diff-in-diff framework (Tab. A10, col. 1-3). No effects are discernible in the sample of non-agricultural workers (Tab. A10, col. 4-6), suggesting that the relaxation of parameter restrictions on the covariates in equation (1) does not change our results. The findings in Tab. A10 also imply that there are no short-run spill-overs to the nonagricultural sector.

To focus more closely on the separate wage response between free and coerced workers we split the sample by farm size, defining small farms as those with at most 25 employees. As mentioned above, we chose this employment size based cut-off to separate employment in small private dehkan farms and large parastatal/state-owned farms. ${ }^{28}$ Only the latter command the political connections required for coercing workers.

We find hourly wage gains exclusively for women in small farms while agricultural laborers on large farms and men do not benefit (Tab. 3, A11, A12). ${ }^{29}$ For robustness we also

\footnotetext{
${ }^{28}$ This method works very well according to expert interviews in Tajikistan and evidence from GIZ data.

${ }^{29}$ The results hold for using different cut-offs to define small and large firms (Tab. A12). Similar to Tab. A10, we also estimate the specifications of Table 3 for the sub-samples of agricultural and non-agricultural workers and find similar results (Tab. A11). Alternatively, we include a dummy for working at a small firm and its interactions with cotton PSU, agri and year dummies in specification (1) and estimate this quadruple diff. The
} 
experiment with other large firm size cut-offs such as 16 or 50 employees; however, our results hold irrespective of this choice (Tab. A12). The wage response appears quite substantial as cotton pickers enjoy a more than doubling of their hourly wages. Importantly, picking wages are the only source of compensation for workers (rarely supported by the inkind provision of cotton stalks). Pickers do neither receive free services nor other forms of compensation (like bonuses), so that the wage data fully reveal differences in the treatment of workers on both farm types (note that including the sporadic provision of cotton stalks in-kind into the wage definition in Tab. A13 does not alter our results).

Given that labor costs make up only $10-15 \%$ of total production cost in the cotton sector (Sattar and Mohib 2006), there is plenty of scope for other winners from the cotton price hike, and we will turn to other effects in subsection 3.

Finally, we turn to the effect of the cotton price hike on income generation more broadly. By analysing monthly earnings, we can shed light on intra-marginal responses to increased wages. For instance, cotton pickers might well use their higher wage rates to afford more leisure, i.e. reduce monthly working hours. In essence, the tremendous changes to wage rates may not fully translate into income gains. We find some evidence for such a behavioral response: While monthly earnings do increase for female cotton pickers, they increase by only half the amount of hourly wages (Tab. 3 and A15). As a consequence, women seem to afford more leisure.

Table 3: Effects on hourly wages and monthly earnings for coerced (large farm) vs. free (small farm) workers

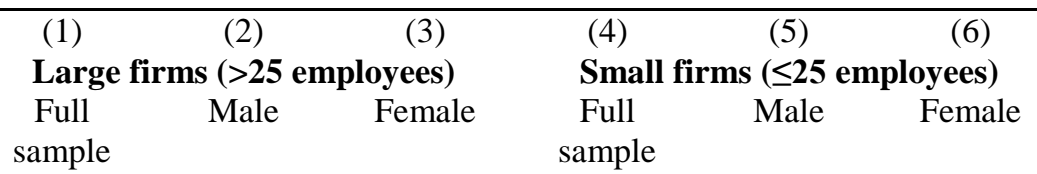

Dependent variable

Log of the real wage per hour

$\begin{array}{lcccccc}\text { CottonPSU*year2009*Agri } & -0.44 & -0.49 & -0.30 & -0.08 & -0.23 & -0.01 \\ & (0.30) & (0.35) & (0.31) & (0.34) & (0.41) & (0.38) \\ \text { CottonPSU*year2011*Agri } & -0.30 & -0.36 & -0.10 & 0.31 & -0.06 & 1.10^{* * *} \\ & (0.27) & (0.37) & (0.35) & (0.27) & (0.29) & (0.35) \\ & & & & & & \\ \text { Observations } & 2,984 & 1,706 & 1,278 & 3,818 & 2,702 & 1,116 \\ \text { R-squared } & 0.52 & 0.47 & 0.51 & 0.32 & 0.28 & 0.38 \\ \text { Adjusted R-squared } & 0.504 & 0.442 & 0.473 & 0.308 & 0.260 & 0.335\end{array}$

results are very similar to the sample split. Alternatively, we define small private farms using a survey question indicating whether a respondent works in a household enterprise. Using this definition gives similar results. 


\begin{tabular}{|c|c|c|c|c|c|c|}
\hline CottonPSU*year2009*Agri & $\begin{array}{c}-0.43^{*} \\
(0.25)\end{array}$ & $\begin{array}{l}-0.32 \\
(0.32)\end{array}$ & $\begin{array}{l}-0.37 \\
(0.26)\end{array}$ & $\begin{array}{l}-0.12 \\
(0.29)\end{array}$ & $\begin{array}{l}-0.28 \\
(0.33)\end{array}$ & $\begin{array}{c}0.03 \\
(0.34)\end{array}$ \\
\hline CottonPSU*year2011*Agri & $\begin{array}{l}-0.18 \\
(0.21)\end{array}$ & $\begin{array}{l}-0.22 \\
(0.30)\end{array}$ & $\begin{array}{c}0.01 \\
(0.28)\end{array}$ & $\begin{array}{c}-0.03 \\
(0.22)\end{array}$ & $\begin{array}{l}-0.22 \\
(0.25)\end{array}$ & $\begin{array}{c}0.66 * * \\
(0.32)\end{array}$ \\
\hline Observations & 3,009 & 1,723 & 1,286 & 3,850 & 2,721 & 1,129 \\
\hline R-squared & 0.53 & 0.48 & 0.50 & 0.41 & 0.32 & 0.39 \\
\hline Adjusted R-squared & 0.521 & 0.451 & 0.461 & 0.392 & 0.302 & 0.346 \\
\hline \multicolumn{7}{|c|}{$\begin{array}{l}\text { Note: In the upper panel, the dependent variable is the log of the real wage per hour in the last month. The lower panel shows results for the } \\
\text { dependent variable log of the real monthly earnings. Columns } 1-3 \text { only include individuals that work in firms with more than } 25 \text { employees } \\
\text { (column } 1 \text { refers to the full sample, whereas column } 2 \text { and } 3 \text { show results for the male and female sub-samples, respectively), whereas } \\
\text { columns } 4-6 \text { show results for individuals that work in firms with at most } 25 \text { employees (column } 4 \text { refers to the full sample, whereas column } 5 \\
\text { and } 6 \text { show results for the male and female sub-samples, respectively). All specifications are estimated using OLS and include district } \\
\text { dummies, province-year dummies, dummies for the month of the interview as well as dummies for cotton PSU, the year of the interview and } \\
\text { a dummy for working in agriculture (agri) as well as all interactions of cotton PSU, the year dummies and the agri dummy. The individual } \\
\text { controls shown in Tab. } 2 \text {, i.e., sex, age, dummies for the education and occupation of the individual as well as for working in a very large } \\
\text { firm or in a state firm, are also included in all specifications, but are not shown in the table. Robust standard errors (clustered at the PSU } \\
\text { level) in parentheses } * * * \text { p }<0.01, * * p<0.05, * \text { p }<0.1 \text { Source: TLSS } 2007-11 \text {. }\end{array}$} \\
\hline
\end{tabular}

\subsection{Elasticities}

In order to quantify the effect of the cotton price shock in a more intuitive manner, we estimate the price pass-through as the elasticity of wages with respect to the cotton price:

$$
\begin{aligned}
& \ln (\text { realwageph })_{\text {it }} \\
& =\alpha+\beta_{1} \ln \left(\mathrm{p}_{t}\right)+\beta_{2}\left(\operatorname{cottonPSU} \times \ln \left(\mathrm{p}_{t}\right)\right)+\beta_{3}\left(\operatorname{agri} \times \ln \left(\mathrm{p}_{t}\right)\right) \\
& +\beta_{4}\left(\operatorname{cottonPSU} \times \operatorname{agri} \times \ln \left(\mathrm{p}_{t}\right)\right)+\beta_{5}(\operatorname{agri} \times \operatorname{cottonPSU})+\beta_{6} \text { agri } \\
& +\beta_{7} \operatorname{cottonPSU}+\mathrm{X}_{\mathrm{it}}{ }^{\prime} \gamma+\tau+\mathrm{u}_{\mathrm{it}}
\end{aligned}
$$

We construct a price measure $\mathrm{p}_{\mathrm{t}}$ that equals the average yearly cotton FOB export price for cotton PSUs and the average yearly wheat CIF import price for non-cotton PSUs, since wheat is the main non-cotton crop of Tajikistan and domestic wheat prices closely follow international prices as the country is a net importer (USAID 2011). The pass-through of cotton prices to agricultural wages in cotton PSUs compared to the pass-through of wheat prices to agricultural wages in non-cotton PSUs is measured by $\beta_{4}$. For robustness, we also run these regressions with average sowing period (January until March) and average harvest (two weeks before the respective interview) prices.

We will only show results for women since results for male workers are always insignificant. Their results, however, can be obtained on request. The results show a slightly inelastic wage response for the average yearly and sowing price respectively, while during harvest time the response of female agricultural wages to changes in the cotton export price is slightly above unit-elastic (Tab. 4). 
Using these elasticities, we can rationalize the regression results from Tab. 2 column 6:

$$
\Delta p \times \epsilon_{w p} \approx 0.9 \approx \exp (0.62)-1,
$$

where $\Delta p$ is the cotton price change between the sowing periods of 2007 and 2011, $\epsilon_{w p}$ is the cotton price elasticity of agricultural wages and the expression behind the equal sign is the result from Tab. 2 column 6 expressed in percent. Tab. 4 reports remarkably similar results irrespective of whether we use the yearly, sowing or harvest price of cotton.

Table 4: Output price elasticities of wages and wage effects implied by different elasticities

(1)

Yearly prices
(2)

Sowing period prices Harvest period prices

\section{Dependent variable}

$\begin{array}{lc}\text { Lnprice*Agri*cottonPSU } & 0.69^{*} \\ & (0.36) \\ \text { Lnprice } & 0.88^{* * *} \\ & (0.18) \\ \text { Lnprice*cottonPSU } & -0.48 * * \\ & (0.18) \\ \text { Lnprice*Agri } & -0.28 \\ & (0.36) \\ & \\ \text { Observations } & 2,394 \\ \text { R-squared } & 0.40 \\ \text { Adjusted R-squared } & 0.381\end{array}$

Log of the real wage per hour

$\begin{array}{lcc}0.69 * & 0.41 & 1.13^{* *} \\ (0.36) & (0.26) & (0.52) \\ .88^{* * *} & 0.48^{* * *} & 0.87 * * * \\ (0.18) & (0.12) & (0.22) \\ -.48^{* *} & -0.17 & -0.17 \\ 0.18) & (0.12) & (0.26) \\ -0.28 & -0.11 & -0.32 \\ 0.36) & (0.26) & (0.47) \\ & & \\ 2,394 & 2,394 & 2,394 \\ 0.40 & 0.40 & 0.39 \\ 0.381 & 0.379 & 0.374\end{array}$

$1.13 * *$

$87 * *$

$(0.22)$

$-0.17$

0.32

39

0.374

Wage effects implied by different elasticities

$\begin{array}{cccc}\Delta p & 157 \% & 214 \% & 68 \% \\ \epsilon_{w p} & 0.69 & 0.41 & 1.13 \\ \Delta p \times \epsilon_{w p} & 1.1 & 0.9 & 0.8\end{array}$

\begin{abstract}
Note: In the upper panel, the dependent variable is the log of the real wage per hour in the last month. The independent variable Lnprice is the $\log$ of crop prices, whereby in column 1 the price equals the average yearly cotton FOB export price (of Tajikistan) for cotton PSUs and the average yearly wheat CIF import price (of Tajikistan) for non-cotton PSUs. Instead of average yearly prices, we use average sowing period prices (January until March) in column 2 and average harvest prices (two weeks before the respective interview) in column 3. In robustness checks not shown here, we also used the world market prices for cotton and wheat instead of FOB and CIF prices for Tajikistan and results do not change. All specifications are estimated for the sample of female workers using OLS and include district dummies, province-year dummies, dummies for the month of the interview as well as dummies for cotton PSU, a dummy for working in agriculture (agri) and the interaction of cotton PSU and the agri dummy. The individual controls shown in Tab. 2, i.e., sex, age, dummies for the education and occupation of the individual as well as for working in a very large firm or in a state firm, are also included in all specifications, but are not shown in the table. The lower panel shows the results of a simple computation of the wage effects that are implied by the computed elasticities $\epsilon_{w p}$ in the upper panel. Note that $\Delta p$ is computed according to the official export price of Tajikistan. Robust standard errors (clustered at the PSU level) in parentheses $* * * \mathrm{p}<0.01, * * \mathrm{p}<0.05, * \mathrm{p}<0.1$ Source: TLSS 2007-11.
\end{abstract}

\title{
4.4. Effects on child labor and manager profits
}

Besides female agricultural laborers, other labor market subgroups might have been directly affected by the price changes of cotton. Child labor has for long contributed to cotton 
harvesting in Tajikistan and beyond. During harvest time, entire schools were temporarily closed in order to send school children to the fields (van Atta 2009, ILRF 2007). While this phenomenon has been on decline for several years, reports of involuntary child labor in cotton picking have not disappeared. We define child labor for children and adolescents up to age 17. Tab. 5 (col. 1-3) indicates a significant expansion in the incidence of child labor in cotton PSUs in the year of the cotton price hike. Across both sexes, the probability that adolescents work during the reference week in the harvest period is roughly two percentage points higher (which represents a relative change of $67 \%) .{ }^{30}$ This finding confirms the existence of labor coercion as child labor is never considered voluntary against the background of compulsory school attendance. It also illustrates an important welfare reducing effect of labor coercion: If school children miss time at school, this will hinder their human capital accumulation.

Table 5: Child labor in cotton picking and earnings of managers

\begin{tabular}{|c|c|c|c|c|c|}
\hline \multirow[b]{4}{*}{ Dependent variable } & (1) & (2) & (3) & $(4)$ & $(5)$ \\
\hline & \multicolumn{3}{|c|}{ Children up to 17 years old } & \multicolumn{2}{|c|}{ Working Population } \\
\hline & $\begin{array}{c}\text { Full } \\
\text { Sample }\end{array}$ & Male & Female & Full Sample & Full Sample \\
\hline & Dummy & $\begin{array}{l}\text { iable fo } \\
\text { sricultu }\end{array}$ & rking in & $\begin{array}{c}\text { Log of } \\
\text { hourly wage }\end{array}$ & $\begin{array}{c}\text { Log of real } \\
\text { earnings per } \\
\text { month }\end{array}$ \\
\hline \multirow[t]{2}{*}{ CottonPSU*year2009 } & 0.00 & -0.00 & 0.01 & & \\
\hline & $(0.01)$ & $(0.02)$ & $(0.02)$ & & \\
\hline \multirow[t]{2}{*}{ CottonPSU*year2011 } & $0.02 *$ & $0.03 *$ & 0.02 & & \\
\hline & $(0.01)$ & $(0.01)$ & $(0.02)$ & & \\
\hline \multirow[t]{2}{*}{ CottonPSU*2011*agri*large*manager } & & & & $0.63 * * *$ & $0.99 * * *$ \\
\hline & & & & $(0.19)$ & $(0.15)$ \\
\hline \multirow[t]{2}{*}{ CottonPSU*2011*agri*small*manager } & & & & $0.74 * * *$ & 0.26 \\
\hline & & & & $(0.22)$ & $(0.21)$ \\
\hline Observations & 11,238 & 5,658 & 5,580 & 8,069 & 8,137 \\
\hline R-squared & 0.08 & 0.06 & 0.11 & 0.41 & 0.45 \\
\hline Adjusted R-squared & 0.0701 & 0.0463 & 0.0952 & 0.400 & 0.445 \\
\hline
\end{tabular}

Note: In the base year, $3 \%$ of children engage in child labor. In columns 1-3, the dependent variable is an indicator whether the child works in agriculture or not, whereby we use the sample of children up to age 17 (column 1 refers to the full sample, whereas column 2 and 3 show results for the male and female sub-samples, respectively). In columns 4 , the dependent variable is the log of the real earnings per hour in the last month, and in column 5 it is the log of the real earnings per month. The specifications in columns 4 and 5 are estimated for all individuals reporting any monetary earnings. All specifications are estimated using OLS and include district dummies, province-year dummies, dummies for the month of the interview as well as dummies for cotton PSU and the year of the interview. The individual controls shown in Tab. 2, i.e., sex, age, dummies for the education and occupation of the individual as well as for working in a very large firm or in a state firm, are also included in all specifications, but are not shown in the table. Columns 4-5 additionally include a dummy for working in agriculture (agri), a dummy for working in a small firm (small) and a dummy whether the individual is an employee or the owner of the firm (manager) and all interactions of cotton PSU, the year dummies and the agri, small and manager dummies. Columns 1-3 include additional control variables at the individual, PSU and sub-district level. Individual controls are available from the TLSS for each year of the sample and comprise dummies for the ethnicity and the marital status of the individual as well as household size. PSU level controls are for the year 2007 and include the distance of the PSU to the province capital, a dummy for urban location as well as measures for the importance of agriculture and male unemployment in the PSU. Sub-district level control variables come from the World Bank Socio-Economic Atlas of Tajikistan (2005) and refer either to the year 2003 or the year 2000. They comprise the unemployment rate, the dependency ratio, the share of the economically active (female) population, the share of households living below the poverty line, the log of the population density, the share of individuals with primary education completed and the share with secondary education completed, the share of households with electrical power supply in the dwelling as well as the share of households with a landline phone. Robust standard errors (clustered at the PSU level) in parentheses $* * * \mathrm{p}<0.01, * * \mathrm{p}<0.05, * \mathrm{p}<0.1$ Source: TLSS 2007-11.

\footnotetext{
${ }^{30}$ These findings are robust to the inclusion of individual fixed effects (Tab. A18).
} 
Given that wages comprise only $10-15 \%$ of production costs, the doubling of the cotton price leaves ample scope for further beneficiaries from the price hike. After all, if large parastatals were exploiting their political connections in order to attract labor cheaply, where would the sharply rising revenues go? Anecdotal evidence suggests that farms increased their profits and that farm managers/owners appropriated large income gains: several small private farmers explained in our qualitative interviews that managers of parastatals purchased big cars as a consequence of higher revenues. ${ }^{31}$ Now, we test this more formally by analysing managers'owners' incomes (hourly wages and monthly earnings). Fortunately, we can identify farm managers/owners by combining individual occupation (e.g., manager or majority farm owner) with sector of operation (e.g., agriculture). We now include these farm managers (and managers in other sectors) in our sample and adjust our previous estimation strategy in a way to distinguish between employees and farm owners/managers. We estimate a quintuple difference estimator by enriching specification (1) with a dummy for working in a small firm and a dummy for being a manager (or the owner) as well as all interactions between these two dummies and the dummies for cotton PSU, working in agriculture and the year dummies. ${ }^{32}$ We present only the most relevant interactions for managers/owners in Tab. 5 (col. 4 and 5).

The earnings of farm managers increased disproportionally during the cotton price hike on both farm types. In effect, while on small farms workers and managers see an increase in wages, the only beneficiaries on large farms are managers. Yet, the effect is fully concentrated in the male subsample (separate results not shown). For women, who hold little management/ownership positions in our sample (only 37 percent of small farms are run by a women $^{33}$ ), the estimate is imprecisely estimated for small farms. On large farms, we observe no single women in a management position. On first sight, managers on small farms seem to earn disproportionally more than managers on large farms; however, this effect reverses once we account for potential labor supply adjustments by analysing monthly earnings rather than hourly wages. On a monthly basis, only managers of large farms reap substantial benefits

\footnotetext{
${ }^{31}$ There are several reasons why managers could be benefitting strongly. While incentive contracts or corruption are potential explanations, the most likely reason is rent capture. The ownership structure in agricultural collectives is fragmented and the supervision of managers is often incomplete. In general, profits of managers on parastatal farms are much higher than of those on private farms (Sattar and Mohib 2006; see also Tab. A9).

${ }^{32}$ We could not estimate the regression for the subsample of managers/owners of small vs. large farms, because there are too few managers/owners in the dataset (57 large farm managers and 189 small farm managers).

${ }^{33}$ In fact, we observe many female headed small farms because their husbands seasonally migrated to Russia. Those women may not be fully responsible for handling the profits of the farm.
} 
from the cotton price hike. This may even be understated due to likely underreporting of profits by large farm mangers involved in the rent seeking networks of the cotton sector.

\subsection{Evidence on the political economy of labor coercion}

So far we have relied on mounting evidence regarding differences in political connections between managers of small vs. large farms. We have also conducted more than 50 qualitative interviews with cotton-pickers, private farmers, farm managers, politicians as well as staff members of NGOs and International Organisations such as the World Bank or GIZ - the German development agency (see list in the Appendix D). Clearly, political connections were reported to be exclusively based on farm type and, hence, farm size. Almost all of our interview partners were in agreement that large parastatal farms (unlike private dehkan farms) exploit political connections to coerce workers, pupils and students. This practice is aided by threat of force (e.g. to expel students from university) and by social norms according to which workers on large farms see no alternative; most workers of parastatals even lack the perception that labor coercion may be illegal. Importantly, workers on large parastatal farms are enlisted according to labor requirements and there is no insurance component in the worker-farm relationship which might support cotton pickers at times of low labor demand.

The connections between local politicians and managers of large farms are remnants from the command economy era when economic plans and production targets were politically defined and enforced in exchange for 'political support' during harvest time. In a 2011 survey among 672 political leaders (GIZ political leader survey), about $60 \%$ of politicians in districts with parastatal enterprises reported that they still communicated production targets to farm managers directly and that they charged officials to support farms. This suggests that links between politicians and managers are still vital.

According to a survey conducted by GIZ among 253 farm managers in Tajikistan in 2011, the local (jamoat) or regional (hukumat) political elite influences farming decisions significantly more often on large parastatal compared to small private farms. More than one third of farm managers, for instance, fears negative political consequences in case they dedicated smaller areas to cotton production. This is unsurprising since managers of large parastatal farms still tend to be elected or appointed by hukumat officials (GIZ 2011). 


\subsection{Robustness checks}

It is reassuring that all our main results from Tab. 2-5 are robust to the inclusion of individual fixed effects (Tab. A15-A18), which shows that unobserved heterogeneity at the individual level does not bias our findings. Moreover, we conduct various robustness checks using additional data obtained during our field research in Tajikistan (see Appendix B).

The following section rules out three potential alternative explanations: The first hypothesis suggests that the privatization process might be responsible for the observed passthrough patterns; the second explains the wage effects by productivity differences between small and large farms; and, the third suggests that the absence of wage gains after the cotton price hike can be explained by monopsony power rather than by political connections. We also shed more light on the general labor market responsiveness of different farm types and test whether our results are sensitive to the chosen specification regarding the treatment definition.

First, one potential threat to our identification could stem from disproportionate privatization of land between the survey years 2009 and 2011. We use data from the Tajik State Committee for Land and Geodesy (SCLG) on newly issued land use certificates for farms with at most 25 employees to investigate the privatization process over the period between 2007 and 2011; however, we do not find any increase in the number of newly issued SCLG land use certificates between 2009 and 2011. To lend further robustness to our results we repeat our main analysis and include a control variable that reflects the number of newly issued SCLG land use certificates per municipality (Jamoat). As expected, this does not change our finding of significantly higher wages for female cotton pickers on small farms (Tab. A19 und A20). This indicates that the privatization process is not driving our results.

Second, if wages fully reflected labor productivity, wage differences between farm types may simply reflect a selection of more productive workers in small private farms. To test this potential explanation, we compare labor productivity differences in the GIZ farm survey for the year 2013 (Tab. 1). For this we relate a measure of cotton yield per ha to a measure of worker per ha, resulting in cotton output per unit of labor input. It turns out that the average worker on large and small farms produces $968 \mathrm{~kg}$ and $964 \mathrm{~kg}$ of cotton, respectively. ${ }^{34}$ This remarkably similar productivity is a clear indication against selection of productive workers into specific farm types. Also, anecdotal evidence suggests that attracting

\footnotetext{
${ }^{34}$ Given a total net harvest period of roughly four weeks the total daily productivity in Tajikistan is similar to Antebellum productivity per worker in America, where one person picked around 100 pounds per day.
} 
additional workers to the workforce does not lead to productivity decline since the required skill level is very low.

Third, if the missing wage effects in large farms was to be explained by monopsony power of parastatals, this would require large farms to artificially suppress the labor intensity (per ha) on its farms in order to put pressure on wages. As Tab. 1 reveals using data from a farm survey conducted by the GIZ, the number of workers per hectar (i.e., the labor intensity of production) on large and small farms is almost identical; this is also true for female workers per hectar, the most relevant group once it comes to cotton picking. Similarly, the cotton yields in $100 \mathrm{~kg}$ cotton per ha are remarkably close. In fact, small and large farms use very similar labor-to-land ratios as input, making the use of monopsony power on large farms a very unlikely explanation. ${ }^{35}$ Furthermore, we test the monopsony power explanation by including the share of agricultural workers working on small private farms per district (and per PSU) as control variable in our main wage regressions (Tab. A19 and A20). ${ }^{36}$ A higher share of workers on small farms should indicate a higher degree of competition between farms in local labor markets and vice versa. The results show that the degree of competition in local labor markets does not explain our findings of increased agricultural wages (on small farms) in cotton PSUs compared to non-cotton PSUs from 2007 until 2011.

A related question is whether local labor market conditions are reflected in wage responses: In more responsive (i.e., functional) labor markets faced by small private farms we would expect a negative correlation between the level of unemployment and wage levels of female cotton pickers. On large parastatal farms commanding a large pool of coerced workers, wages should not react to local labor market conditions. Indeed, we find that women's wages on smaller and more market-oriented farms decrease with rising unemployment rates while the correlation is zero for wages on large farms (Tab. A21). This clearly indicates the structural differences between labor markets faced by small private vs. large parastatal farms.

Furthermore, we test the robustness of our results with a number of alternative specifications. Specifically, we exploit different definitions of cotton-suitable areas (according to production capacity in the FAO GAEZ data or according to altitude based measures; see Tab. B-1 in the Appendix for details) as well as different aggregation methods for cotton areas (at district rather than PSU level). Employing these alternative treatment definitions leads to

\footnotetext{
${ }^{35}$ Another fact against the monopsony power explanation is that in less than $5 \%$ of all PSUs small farms are entirely missing so that the market power of parastatals will be limited.

${ }^{36}$ The results for the share of small farm workers per PSU are not shown here, but can be requested from the author. The results are similar to the ones presented in Tab. A19 and A20.
} 
the same strong results as in the main regressions (Tab. A23, A24). Furthermore, we use the production of cotton as well as the area harvested with cotton per district as a continuous treatment variable and interact it with the share of agricultural workers working on small farms (at most 25 employees) per district. The results indicate that an expansion of the area under cotton/cotton production and the subsequent increase in harvest-time labor demand raises agricultural wages only if the district has a high share of agricultural workers on small farms (Tab. A22). This reinforces our finding that increasing labor demand for cotton pickers translates into higher wages on small farms only. Finally, we include additional control variables at the individual, household, PSU and sub-district level (Tab. A21) and we restrict our estimation sample only to laborers who were working on small private and large parastatal farms before and after the cotton price hike, respectively (results available upon request). None of these alternative approaches casts doubt on our main results.

\section{Conclusion}

Much of today's consumption relies on global supply chains that link consumers to producers worldwide. Occasional media attention points to the weakest link in these chains: Workers in the labor-intensive cotton, garment, mining and staple food sectors of developing countries who are vulnerable to labor coercion. Exploiting the unexpected doubling of the world market price of cotton in 2010/2011, this paper has identified the commodity price effect on wages of free vs. coerced cotton pickers. Using new panel data from Tajikistan, we employ a difference-in-differences strategy based on variation in geographic suitability for cotton production, exogenous labor supply conditions as well as price and labor demand variation over time. Our main focus is on the differential treatment of free cotton pickers on market oriented small private farms vs. workers coerced by large parastatal farms.

The wage increase following the 2011 expansion of cotton production is substantial. While women, who form the largest part of the cotton workforce, gain from the price hike (real hourly wages increase by 86 percent), no comparable benefits can be detected for men. The increase in wages is, however, fully concentrated among women working on small private dehkan farms while their peers on parastatal or state-owned farms gain close to nothing. Our findings, hence, suggest that the positive effect of the price shock operates through the labor market: Workers on private farms are recruited for the harvest season on the local labor market while parastatal farms exploit their political connections to coerce workers 
of other state-owned enterprises, university students and school children into cotton picking. Perfectly elastic labor supply for parastatal farms let the wages of their workers stagnate at the level of the minimum wage during the cotton price surge in 2011. In addition, our regression results and qualitative interviews suggest that the incidence of child labor went up. At the same time, higher cotton proceeds and firm profits were appropriated by farm managers rather than distributed to workers in large parastatal firms.

While this time, the rise in the world market price of cotton benefitted one part of the workforce, the effects of an equally likely drop in the world market price depend on the design and quality of market institutions in Tajikistan. The existence of the national minimum wage puts a lower bound on wages in both farm types. More importantly, plummeting cotton prices would probably push private farmers into crop diversification thus mitigating the negative impact of a potential cotton price slump. Therefore, an adequate strategy to mitigate the risk of cotton price fluctuations is to effectively secure free crop choice of farmers.

This paper sheds light on the link between international trade and the labor market conditions of some of the most disadvantaged workers in basic tradable commodity markets in developing countries. While working conditions in the cotton sector of Tajikistan are generally harsh, we observe strong wage adjustments following increased demand in the market oriented branch of the cotton production sector. This result is not confounded by a changing skill composition of the workforce as illustrated by our estimation that controls for individual heterogeneity. Our results are short-run estimates of the pass-through of worldmarket price fluctuations on labor inputs. In the long run, firms might in theory adjust their capital stock, which however is less practicable in labor-intensive commodities like cotton and less affordable for credit-constrained private farmers who are found to behave in correspondence with market incentives. Large parastatal farms seem to be severely plagued by rent-seeking behavior of managers, cotton gins and local politicians. According to our results, the global hunger for basic commodities benefitted some of the poorest workers as long as basic market rules are respected. Hence, this paper suggests that the privatization process in Tajikistan has succeeded in establishing a relatively competitive and entrepreneurial agricultural sub-sector that created new income opportunities for poor landless women in rural villages. Worryingly, the privatization process has stalled preventing many farmers from potential future gains.

These changes in employment and wages have substantial social implications: While women who work in the cotton sector are normally considered the most deprived part of the 
workforce without social benefits (International Crisis Group 2005), the cotton price hike was beneficial for some of them. The expansion in paid labor market participation of women will most likely have benefitted their absolute and relative economic standing and bargaining power within households and within society as a whole. Our results indicate that the passthrough of economic opportunities and benefits critically depends on the market structure and that coercion and threat of force have the potential of trapping individuals and households in poverty. Furthermore, labor coercion adds to economic and social inequalities which have been shown by a recently emerging literature to be persistent even in the long-run.

\section{Acknowledgements}

We thank Jean-Marie Baland, Davide Cantoni, Arnaud Costinot, Natalia Danzer, Gabriel Felbermayr, Richard Frensch, Paul Frijters, Dominika Langenmayr, John Morrow, Olga Shemyakina and participants of seminars and conferences in Dushanbe, London, Manchester, Munich, Nuremberg, Passau, Regensburg, Toulouse, Turin and Tutzing for helpful comments. We are particularly indebted to Craig Hutton, Cem Mete and Andy Murdoch for providing us with data. We also thank the German Federal Enterprise for International Cooperation (GIZ) in Tajikistan who provided us with data, contacts and logistic support for conducting interviews with farmers, gin managers and Tajik officials. 


\section{References}

Acemoglu, D. and A. Wolitzky (2011). The Economics of Labor Coercion. Econometrica, 79 (2), p. 555-600.

Acemoglu, D., C. Garcia-Jimeno and J. A. Robinson (2012). Finding Eldorado: Slavery and long-run development in Colombia. Journal of Comparative Economics, 40, p. 534-564.

Acemoglu, D., A. Finkelstein and M.J. Notowidigdo (2013). Income and Health Spending: Evidence from Oil Price Shocks. Review of Economics and Statistics, 95(4), p. 1079-1095.

Akramov, K.T. and G. Shreedhar (2012). Economic Development, External Shocks, and Food Security in Tajikistan. IFPRI Discussion Paper 01163.

Amiti and Davis (2011). Trade, Firms, and Wages: Theory and Evidence. Review of Economic Studies, 79, p. 1-36

Anderson, K., G. Rausser and J. Swinnen (2013). Political Economy of Public Policies: Insights from Distortions to Agricultural and Food Markets. Journal of Economic Literature, 51(2), p. 423-77.

Angrist, J. D. and A. D. Kugler (2008). Rural windfalls or a new resource curse? Coca, income and civil conflict in Colombia. Review of Economics and Statistics, 90(2), p. 191215.

Attanasio, O., P.K. Goldberg, and N. Pavcnik (2004). Trade reforms and wage inequality in Colombia. Journal of Development Economics, 74(2), p. 331-366.

Autor, D., D. Dorn and G. H. Hanson (2013). The China Syndrome: Local Labor Market Effects of Import Competition in the United States. American Economic Review, 103(6), p. 2121-68.

Barrett, C.B. and P.A. Dorosh. (1996). Farmers' welfare and changing food prices: NonParametric Evidence from Rice in Madagascar, American Journal of Agricultural Economics, 78, p. 656-69.

Black D., T. McKinnish and S. Sanders (2005). The economic impact of the coal boom and bust. The Economic Journal, 115 (April), p. 449-476.

Bobonis, G. and J. Morrow (2014). Labor coercion and the accumulation of human capital. Journal of Development Economics, 108, p. 32-53. 
Brambilla, I. and G.G. Porto (2011). Market structure, outgrower contracts, and farm output. Evidence from cotton reforms in Zambia. Oxford Economic Papers, 63, p. 740-766.

Chiquiar, D. (2008). Globalization, regional wage differentials and the Stolper-Samuelson Theorem: Evidence from Mexico. Journal of International Economics, 74, p. 79-93.

Costinot, A., J. Vogel and S. Wang (2012). Global Supply Chains and Wage Inequality. American Economic Review, 102(3), p. 396-401.

Danzer, A.M., B. Dietz and K. Gatskova (2013). Migration and Remittances in Tajikistan: Survey Technical Report. Working Paper of the Institute for East and Southeast European Studies, Regensburg.

Danzer, A.M. and O. Ivaschenko (2010). Migration patterns in a remittances dependent economy: Evidence from Tajikistan during the global financial crisis. Migration Letters, $7(2)$, p. $190-202$.

Deaton, A. (1999). Commodity Prices and Growth in Africa. Journal of Economic Perspectives, 13(3), p. 23-40.

Dell, M. (2010). The Persistent Effects of Peru's Mining Mita. Econometrica, 78(6), p. 18631903.

Department of State (2010). Trafficking in Persons Report $-10^{\text {th }}$ edition.

Dippel, C., A. Greif and D. Trefler (2015). The Rents from Trade and Coercive Institutions: Removing the Sugar Coating. NBER Working Paper No. 20958.

Edmonds, E.V. and N. Pavcnik (2005). The effect of trade liberalization on child labor. Journal of International Economics, 65, p. 401-419.

Edmonds, E.V. and N. Pavcnik (2006). Trade liberalization and the allocation of labor between households and markets in a poor country. Journal of International Economics, 69 , p. $272-295$.

Food and Agricultural Organization (FAO) (2009). FAO crop and food security assessment mission to Tajikistan. Special report 2009. Download: http://www.fao.org/docrep/012/ak339e/ak339e00.htm

Food and Agricultural Organization (FAO) (2011). Crop and Food Security Assessment Mission Report Tajikistan 2011. Download: http://www.fao.org/docrep/015/an110e/an110e00.pdf 
Food and Agricultural Organization (FAO) (2013). Global Agro-Ecological Zones (GAEZ)

Database. Access: http://gaez.fao.org/Main.html\#

GIZ (2011). The GIZ farm head survey 2011. Dushanbe.

Global Slavery Index (2016). The Global Slavery Index 2016. Walk Free Foundation. URL: https://s3-ap-southeast-2.amazonaws.com/globalslaveryindex.orgassets/downloads/Global+Slavery+Index+2016.pdf. Accessed May 31, 2016.

Goldberg, P.K. and N. Pavcnik (2005). Trade, Wages, and The Political Economy Of Trade Protection: Evidence From The Colombian Trade Reforms. Journal of International Economics, 66(1), p. 75-105.

Goldberg, P.K. and N. Pavcnik (2007). Distributional Effects of Globalization in Developing Countries. Journal of Economic Literature, 45(1), p. 39-82.

Greenstone, M. and E. Moretti (2003). Bidding for industrial plants: Does winning a 'Million Dollar Plant' increase welfare? NBER working paper 9844.

Greenstone, M., R. Hornbeck and E. Moretti (2010). Identifying Agglomeration Spillovers: Evidence from Winners and Losers of Large Plant Openings. Journal of Political Economy, 118(3), p. 536-598.

Heady, Derek (2014). Food Prices and Poverty Reduction in the Long Run. IFPRI Discussion Paper 013.

Hudson, D. and D. Ethridge (1999). Export Taxes and Sectoral Economic Growth: Evidence from Cotton and Yarn Markets in Pakistan. Agricultural Economics, 20:263-276.

International Crisis Group (ICG) (2005). The Curse of Cotton: Central Asia's Destructive Monoculture. Asia Report No. 93.

International Labor Rights Forum (ILRF) (2007). Labor Conditions in the Tajikistan Cotton Industry.

Ivanic, M. and W. Martin (2008). Implications of higher global food prices for poverty in low-income countries. Agricultural Economics, 39(s1), p. 405-416.

Jayachandran, S. (2006). Selling Labor Low: Wage Responses to Productivity Shocks in Developing Countries. Journal of Political Economy, 114(3), p. 538-575. 
Jacks, David S., Kevin H. O'Rourke and Jeffrey G. Williamson (2011). Commodity Price Volatility and World Market Integration since 1700. Review of Economics and Statistics, 93(3), p. 800-813.

Juhn, C., G. Ujhelyi and C. Villegas-Sanchez (2013). Trade Liberalization and Gender Inequality. American Economic Review, 103(3), p. 269-73.

Kassam, S.N. (2011). One explanation for why farmers produce cotton collectively in postSoviet Tajikistan. PhD thesis. University Of British Columbia: Vancouver.

Kaur, S. (2014). Nominal Wage Rigidity in Village Labor Markets. NBER Working Paper No. 20770.

Kovak, B.K. (2013). Regional Effects of Trade Reform: What is the Correct Measure of Liberalization? American Economic Review, 103(5), p. 1960-1976.

Kranton, R. and A.V. Swamy (2008). Contracts, Hold-Up, and Exports: Textiles and Opium in Colonial India. American Economic Review, 98(3), p. 967-989.

Krishna, P., J.P. Poole and M. Zeynep Senses (2012). Trade, Labor Market Frictions, and Residual Wage Inequality across Worker Groups. American Economic Review, 102(3), p. 417-23.

Lerman, Zvi (2012). Agrarian reform of the Republic of Tajikistan. Farm reform and restructuring cooperative development report (final draft). Download: http://departments.agri.huji.ac.il/economics/lerman-main.html

Massell, B.F. (1964). Export Concentration and Fluctuations in Export Earnings: A CrossSection Analysis. American Economic Review, 54(2), p. 47-63.

Naidu, S. and N. Yuchtman (2013). Coercive Contract Enforcement: Law and the Labor Market in Nineteenth Century Industrial Britain. American Economic Review, 103(1), p. $107-144$.

Naritomi, J., R. Soares and J. Assunção (2012). Institutional Development and Colonial Heritage within Brazil. The Journal of Economic History. 72(2), p. 393-422.

Pavcnik, N. (2002). Trade liberalization, entry and productivity improvements: evidence from Chilean plants. Review of Economic Studies, 69, p. 245-76.

Sattar, S. and S. Mohib (2006). Tajikistan: Cotton Farmland Privatization. In Coudouel, A., A.A. Dani and S. Paternostro (eds.) Poverty and Social Impact Analysis of Reforms. Washington DC: The World Bank, p. 453-490. 
Shumway, C. R., R. D. Pope, and E. K. Nash (1984). Allocatable Fixed Inputs and Jointness in Agricultural Production: Implications for Economic Modeling. American Journal of Agricultural Economics Feb. 1984, p. 72-78.

Sukhtanker, S. (2012). Sweetening the Deal? Political Connections and Sugar Mills in India American Economic Journal: Applied Economics, 4(3), p. 43-63.

Swinnen, J. and P. Squicciarini (2012). Mixed Messages on Prices and Food Security. Science, 335, p. 405-406.

TajStat (Agency on Statistics under the President of the Republic of Tajikistan) (2012). Statistical Year Book on Agriculture in the Republic of Tajikistan (Сельское хозяйство Республики Таджикистан статистический сборник). Purchased in Dushanbe in November 2014.

Topalova, P. (2010). Factor Immobility and Regional Impacts of Trade Liberalization: Evidence on Poverty from India. American Economic Journal: Applied Economics, 2, p. 141.

Qian, N. (2008). Missing Women and the Price of Tea in China: The Effect of Sex-Specific Earnings on Sex Imbalance. Quarterly Journal of Economics, 123, 3, p. 1251-1285.

USAID (2011). A Regional View of Wheat Markets and Food Security in Central Asia. With a Focus on Afghanistan and Tajikistan. Download: http://www.wfp.org/content/ regional-view-wheat-markets-and-food-security-central-asia-july-2011

Van Atta, D. (2009). "White Gold" or Fool's Gold? The Political Economy of Cotton in Tajikistan. Problems of Post-Communism, 56(2), p. 17-35.

Warr, P.G. (2001). Welfare Effects of an Export Tax: Thailand's Rice Premium. American Journal of Agricultural Economics, 83(4), p. 903-920.

Warr P.G. (2002). Export Taxes and Income Distribution: The Philippine Coconut Levy. Weltwirtschaftliches Archiv, 138(3), p. 437-457.

Winters, A.L., N. McCulloch, and A. McKay. 2004. Trade Liberalization and Poverty: The Evidence So Far. Journal of Economic Literature, 42(1), p. 72-115.

Wood, A. (1997). Openness and Wage Inequality in Developing Countries: The Latin American Challenge to East Asian Conventional Wisdom. World Bank Economic Review, $11(1)$, p. 33-57. 
World Bank (2005). Socio-Economic Atlas of Tajikistan. Download: http://siteresources.worldbank.org/INTTAJIKISTAN/Resources/atlas_11.pdf

World Bank (2008). Tajikistan Living Standards Measurement Survey 2007 - Basic Information Document. Available at: http://microdata.worldbank.org/index.php/catalog/72

World Bank (2010). Tajikistan Living Standards Measurement Survey 2009 - Notes for Users. Available at: http://microdata.worldbank.org/index.php/catalog/73

World Bank (2012). Tajikistan: Farmer and Farm Worker Perceptions of Land Reform and Sustainable Agriculture in Tajikistan. Report No. AAA81 - TJ.

World Food Programme (WFP) (2005). Tajikistan: Market Profile for Emergency Food Security Assessments. United Nations World Food Programme: Rome. 
Appendices - not intended for publication. 


\section{Appendix A: Additional Figures and Tables}

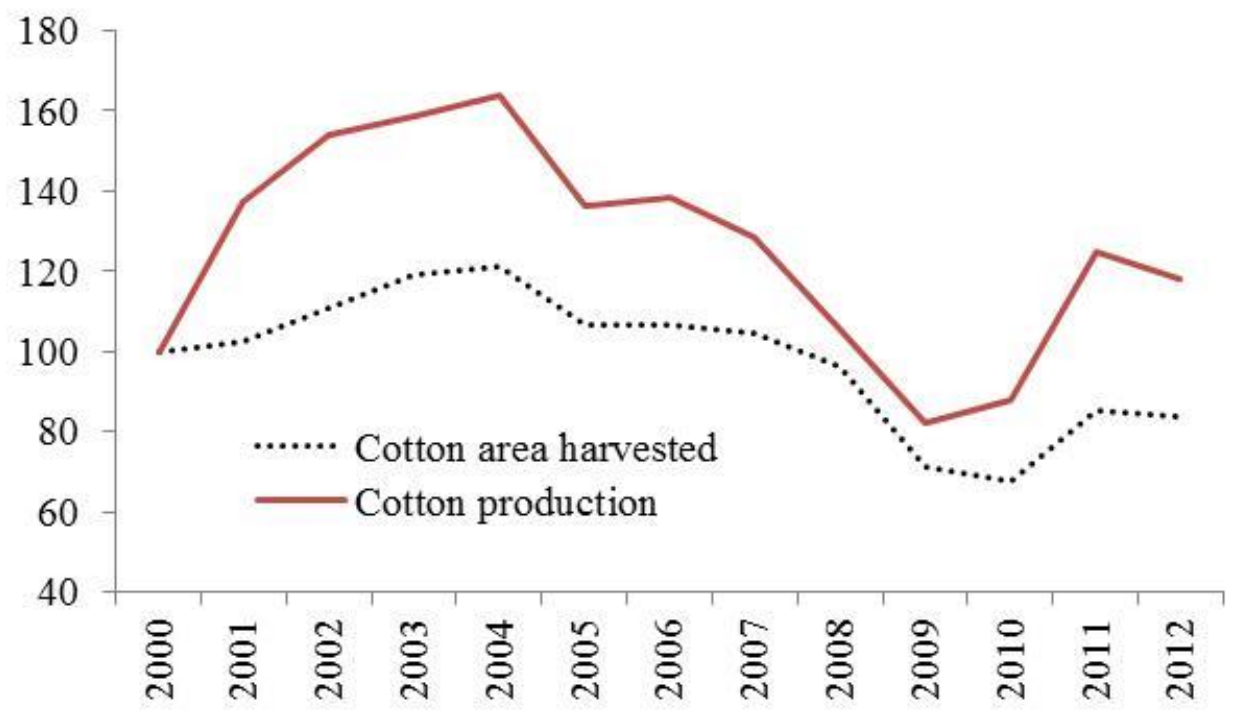

Fig. A1: Cotton production and land area harvested $(100=2000)$

Source: United States Department of Agriculture (USDA) - Foreign Agricultural Service (FAS)

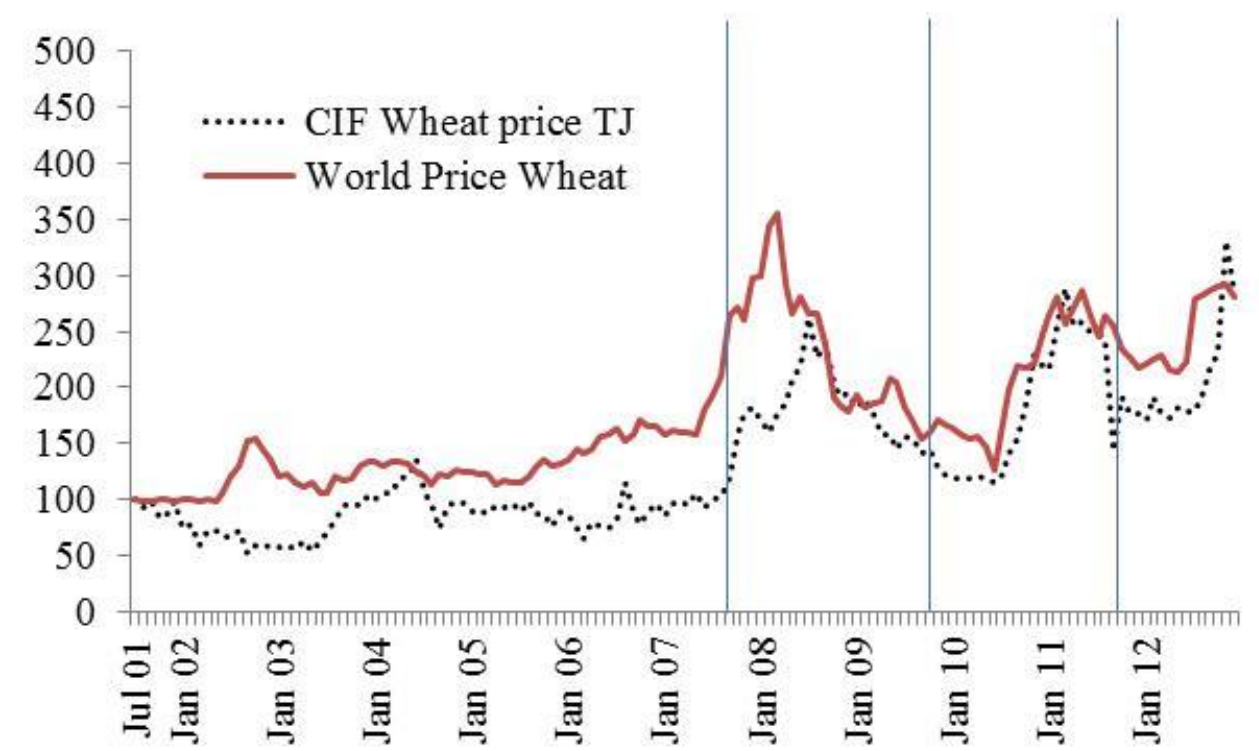

Fig. A2: Wheat world market price $(100=2001)$

Note: Vertical lines mark survey dates. Source: IMF Primary Commodity Prices (Wheat, No.1 Hard Red Winter, ordinary protein, FOB Gulf of Mexico, US\$ per metric ton) and Statistical Agency of Tajikistan 


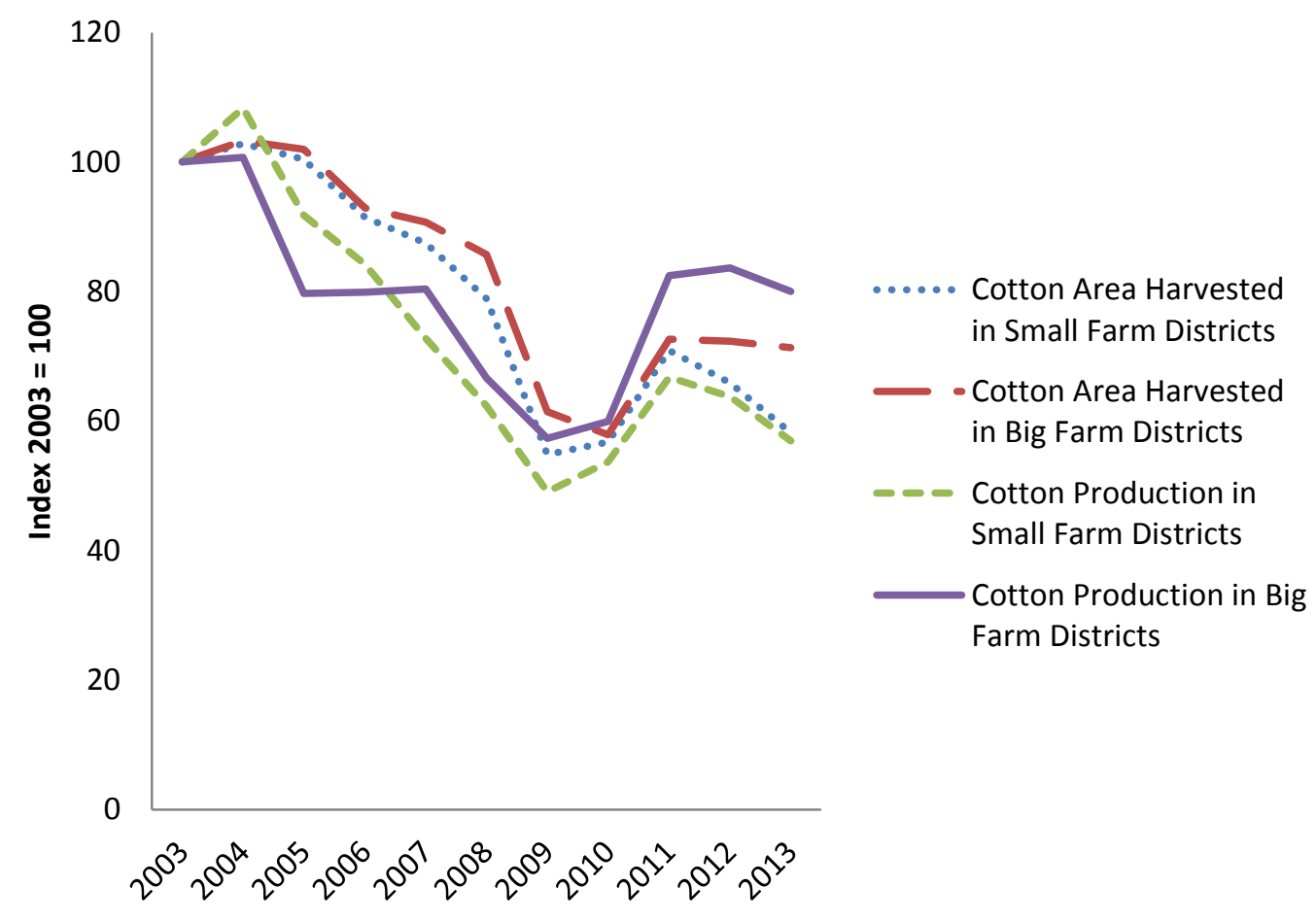

Fig. A3: Cotton production and area harvested in small vs. large farm districts $(100=$ 2003)

Note: Data on cotton production and area harvested with cotton by district comes from the FAO Crop Statistics for Tajikistan. Tajik districts are separated into small and large farm districts using information from the TLSS 2007. We define small (large) farm districts as districts which have a share of agricultural workers working on small farms higher (lower) than $50 \%$

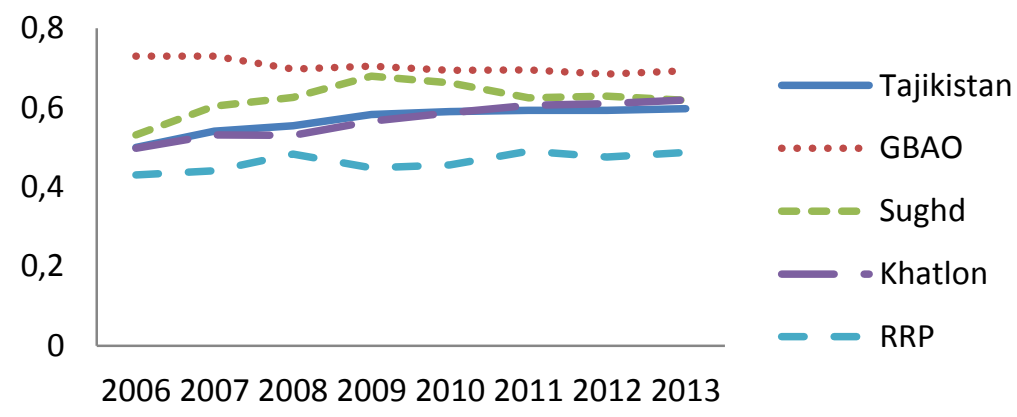

Fig. A4: Share of cultivated area under dehkan farms per province

Source: TajStat 2012 
Table A1: Number of private dehkan vs. collective (parastatal) farms in Tajikistan

\begin{tabular}{lcrrr}
\hline & Number of entities & \multicolumn{3}{c}{ Arable land cultivated in ha } \\
\hline & $\mathbf{2 0 0 6}$ & $\mathbf{2 0 1 0}$ & $\mathbf{2 0 0 6}$ & $\mathbf{2 0 1 0}$ \\
Private dehkan farms & 18040 & 18300 & 324724 & 320000 \\
Collective (parastatal) farms & 9000 & 8300 & 162000 & 165000 \\
\hline Source. FAO Mission reports 2009 and 2011 & &
\end{tabular}

Source: FAO Mission reports 2009 and 2011

Table A2: Farm Head Survey GIZ 2011

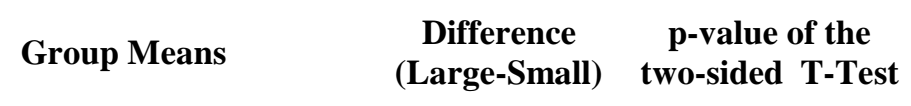

Indicators and variables

\begin{tabular}{|c|c|c|}
\hline & $\begin{array}{c}\text { Small } \\
\text { Farms } \\
(<20 \text { ha })\end{array}$ & $\begin{array}{l}\text { Large Farms } \\
\quad(>20 \text { ha })\end{array}$ \\
\hline
\end{tabular}

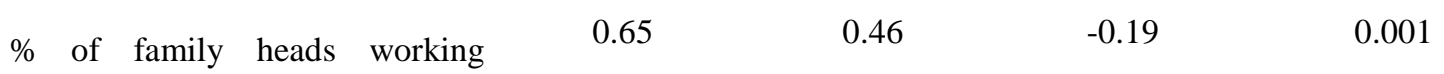

abroad

$(0.05) \quad(0.03) \quad(0.06)$

Losses are added to farm debts, farm manager does not take on

$\begin{array}{llll}0.26 & 0.41 & 0.15 & 0.01\end{array}$

the debts

$(0.04) \quad(0.04) \quad(0.06)$

Farm head is regularly receiving information about world price of

0.04

0.46 cotton

$\begin{array}{lll}(0.04) & (0.04) \quad(0.06)\end{array}$

Spending for social

responsibilities from income of

1418.29

3803.79

2898.39

0

Manager

(250.30) (498.25) (626.13)

Number of observations

126

127

Note: Standard errors in parenthesis. Source: GIZ farm head survey 2011. 
Table A3: Two most important agricultural crops in cotton and non-cotton communities (communities included in the TLSS)

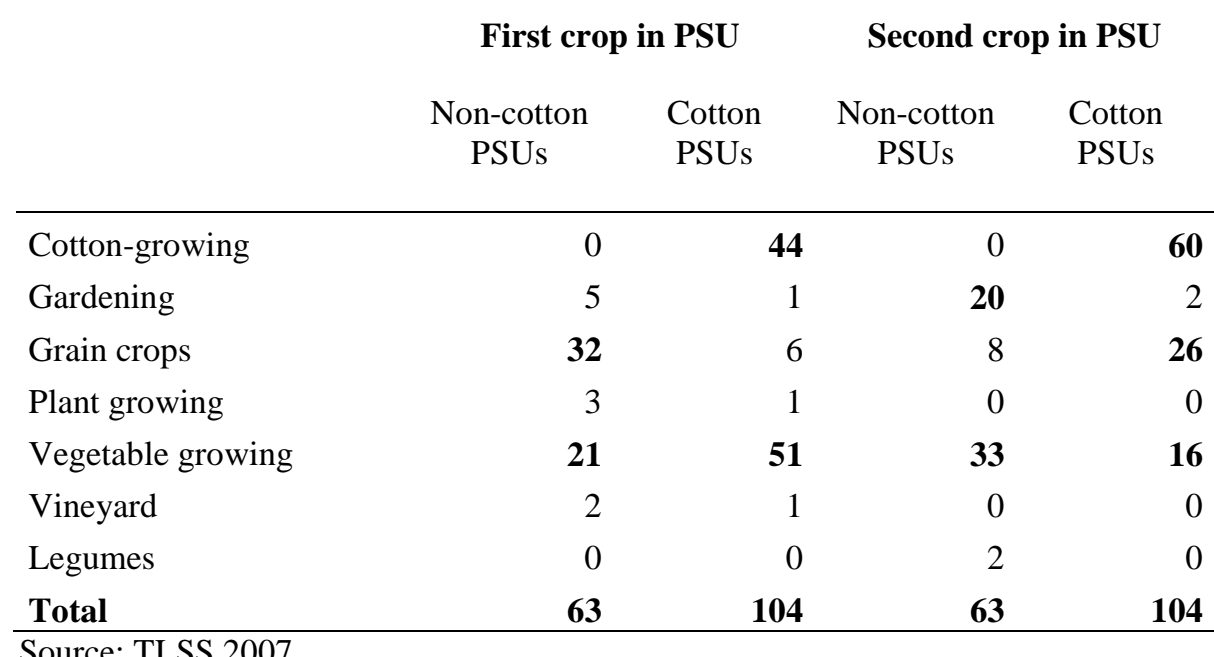

Table A4: Two most important economic activities in cotton and non-cotton communities (PSUs)

\begin{tabular}{|c|c|c|c|c|}
\hline & \multicolumn{2}{|c|}{$\begin{array}{c}\text { First economic activity } \\
\text { in PSU }\end{array}$} & \multicolumn{2}{|c|}{$\begin{array}{l}\text { Second economic } \\
\text { activity in PSU }\end{array}$} \\
\hline & $\begin{array}{l}\text { Non-cotton } \\
\text { PSUs }\end{array}$ & $\begin{array}{l}\text { Cotton } \\
\text { PSUs }\end{array}$ & $\begin{array}{l}\text { Non-cotton } \\
\text { PSUs }\end{array}$ & $\begin{array}{l}\text { Cotton } \\
\text { PSUs }\end{array}$ \\
\hline Agriculture & 55 & 56 & 1 & 2 \\
\hline Mining & 5 & 6 & 2 & 5 \\
\hline Manufacturing & 0 & 5 & 2 & 5 \\
\hline Energy, Gas and Water & 0 & 1 & 1 & 1 \\
\hline Construction & 1 & 1 & 3 & 9 \\
\hline Retail Trade, Restaurants and Hotels & 1 & 30 & 13 & 21 \\
\hline Transport & 0 & 1 & 3 & 5 \\
\hline Finance, Real Estate and Insurance & 0 & 0 & 0 & 2 \\
\hline Public Administration and Defense & 0 & 0 & 2 & 2 \\
\hline Education & 0 & 3 & 29 & 14 \\
\hline Health and Social Services & 0 & 0 & 0 & 8 \\
\hline Other Services & 0 & 0 & 0 & 11 \\
\hline Other & 1 & 1 & 3 & 1 \\
\hline Total & 63 & 104 & 59 & 86 \\
\hline
\end{tabular}


Table A5: Comparison of Cotton and Non-Cotton communities

(Double T-tests or Ranksum-tests)

\begin{tabular}{|c|c|c|c|}
\hline Variable & Cotton PSUs & Non-Cotton PSUs & $\begin{array}{l}\text { P-Value for group } \\
\text { comparison test (H0: } \\
\text { no difference) }\end{array}$ \\
\hline Population & 6600 & 7210 & $68 \%$ \\
\hline Altitude & $684 \mathrm{~m}$ & $1301 \mathrm{~m}$ & $0 \%$ \\
\hline Distance to Dushanbe & $152 \mathrm{~km}$ & $257 \mathrm{~km}$ & $0 \%$ \\
\hline Hours to drive to Dushanbe & $5.9 \mathrm{~h}$ & $9.8 \mathrm{~h}$ & $1 \%$ \\
\hline $\begin{array}{l}\text { Distance to District Capital } \\
\text { Hours to drive to District }\end{array}$ & $13 \mathrm{~km}$ & $25 \mathrm{~km}$ & $0 \%$ \\
\hline Capital & $0.24 \mathrm{~h}$ & $1 \mathrm{~h}$ & $4 \%$ \\
\hline School enrolment & same median & same median & $97 \%$ \\
\hline $\begin{array}{l}\text { Weeks school close because of } \\
\text { agriculture }\end{array}$ & 0.4 & 0.2 & $15 \%$ \\
\hline $\begin{array}{l}\text { Share of population working in } \\
\text { agriculture }\end{array}$ & lower than median & higher than median & $0 \%$ \\
\hline Quality of Roads & better & worse & $1.6 \%$ \\
\hline $\begin{array}{l}\text { Part of crops planted on } \\
\text { irrigated fields }\end{array}$ & higher than median & lower than median & $2 \%$ \\
\hline
\end{tabular}


Table A6: Agricultural workers in cotton regions (treated) vs. agricultural workers in non-cotton regions (control) in 2007

\begin{tabular}{|c|c|c|c|c|c|c|c|}
\hline Variable & $\begin{array}{c}\text { Mean } \\
\text { Control } \\
\text { Group }\end{array}$ & $\begin{array}{c}\text { Mean } \\
\text { Treated } \\
\text { Group }\end{array}$ & Difference & $\begin{array}{c}\text { SE of } \\
\text { Difference }\end{array}$ & P-value & $\begin{array}{c}\mathrm{N} \\
\text { Control }\end{array}$ & $\begin{array}{c}\mathbf{N} \\
\text { Treated }\end{array}$ \\
\hline Wage & 149.25 & 127.84 & 21.41 & 22.04 & 0.33 & 261 & 887 \\
\hline $\begin{array}{l}\text { Dummy for being } \\
\text { female }\end{array}$ & 0.49 & 0.57 & -0.08 & 0.02 & 0.00 & 641 & 1087 \\
\hline Age & 34.22 & 33.33 & 0.89 & 0.67 & 0.19 & 641 & 1087 \\
\hline $\begin{array}{l}\text { Dummy for } \\
\text { primary or no } \\
\text { education }\end{array}$ & 0.39 & 0.28 & 0.11 & 0.02 & 0.00 & 641 & 1087 \\
\hline $\begin{array}{l}\text { Dummy for } \\
\text { secondary educ. }\end{array}$ & 0.57 & 0.69 & -0.12 & 0.02 & 0.00 & 641 & 1087 \\
\hline $\begin{array}{l}\text { Dummy for } \\
\text { tertiary educ. }\end{array}$ & 0.03 & 0.02 & 0.01 & 0.01 & 0.22 & 641 & 1087 \\
\hline $\begin{array}{l}\text { Dummy for } \\
\text { working in a small } \\
\text { firm }(\leq 25 \\
\text { employees })\end{array}$ & 0.82 & 0.43 & 0.38 & 0.02 & 0.00 & 641 & 1087 \\
\hline $\begin{array}{l}\text { Dummy for } \\
\text { working in a very } \\
\text { large firm }(>50 \\
\text { employees) }\end{array}$ & 0.10 & 0.31 & -0.21 & 0.02 & 0.00 & 641 & 1087 \\
\hline $\begin{array}{l}\text { Dummy for high } \\
\text { occupation }\end{array}$ & 0.02 & 0.02 & 0.01 & 0.01 & 0.45 & 641 & 1087 \\
\hline $\begin{array}{l}\text { Dummy for occ. } \\
\text { group } 4,5,7 \text { and } 8\end{array}$ & 0.02 & 0.04 & -0.03 & 0.01 & 0.00 & 641 & 1087 \\
\hline $\begin{array}{l}\text { Dummy for } \\
\text { skilled agricultural } \\
\text { occupation }\end{array}$ & 0.83 & 0.89 & -0.06 & 0.02 & 0.00 & 641 & 1087 \\
\hline $\begin{array}{l}\text { Dummy for } \\
\text { unskilled occup. }\end{array}$ & 0.13 & 0.05 & 0.08 & 0.01 & 0.00 & 641 & 1087 \\
\hline $\begin{array}{l}\text { Hours worked per } \\
\text { week }\end{array}$ & 37.68 & 46.75 & -9.07 & 0.82 & 0.00 & 641 & 1086 \\
\hline
\end{tabular}

Source: TLSS 2007 
Table A7: Agricultural workers in cotton regions on small farms (treated) vs. agricultural workers in cotton regions on large farms (control) in 2007

\begin{tabular}{|c|c|c|c|c|c|c|c|}
\hline Variable & $\begin{array}{c}\text { Mean } \\
\text { Control } \\
\text { Group }\end{array}$ & $\begin{array}{c}\text { Mean } \\
\text { Treated } \\
\text { Group }\end{array}$ & Difference & $\begin{array}{c}\text { SE of } \\
\text { Difference }\end{array}$ & P-value & $\begin{array}{c}\text { N } \\
\text { Control }\end{array}$ & $\begin{array}{c}\mathbf{N} \\
\text { Treated }\end{array}$ \\
\hline Wage & 95.24 & 191.31 & -96.07 & 29.64 & 0.00 & 586 & 301 \\
\hline $\begin{array}{l}\text { Dummy for being } \\
\text { female }\end{array}$ & 0.61 & 0.53 & 0.08 & 0.03 & 0.01 & 615 & 472 \\
\hline Age & 32.70 & 34.15 & -1.45 & 0.79 & 0.07 & 615 & 472 \\
\hline $\begin{array}{l}\text { Dummy for } \\
\text { primary or no } \\
\text { education }\end{array}$ & 0.29 & 0.27 & 0.01 & 0.03 & 0.60 & 615 & 472 \\
\hline $\begin{array}{l}\text { Dummy for } \\
\text { secondary educ. }\end{array}$ & 0.69 & 0.70 & -0.01 & 0.03 & 0.77 & 615 & 472 \\
\hline $\begin{array}{l}\text { Dummy for } \\
\text { tertiary educ. }\end{array}$ & 0.02 & 0.03 & -0.01 & 0.01 & 0.50 & 615 & 472 \\
\hline $\begin{array}{l}\text { Dummy for } \\
\text { working in a small } \\
\text { firm }(\leq 25 \\
\text { employees })\end{array}$ & 0.00 & 1.00 & -1.00 & 0.00 & & 615 & 472 \\
\hline $\begin{array}{l}\text { Dummy for } \\
\text { working in a very } \\
\text { large firm }(>50 \\
\text { employees) }\end{array}$ & 0.54 & 0.00 & 0.54 & 0.02 & 0.00 & 615 & 472 \\
\hline $\begin{array}{l}\text { Dummy for high } \\
\text { occupation }\end{array}$ & 0.01 & 0.03 & -0.01 & 0.01 & 0.10 & 615 & 472 \\
\hline $\begin{array}{l}\text { Dummy for occ. } \\
\text { group } 4,5,7 \text { and } 8\end{array}$ & 0.03 & 0.06 & -0.02 & 0.01 & 0.06 & 615 & 472 \\
\hline $\begin{array}{l}\text { Dummy for } \\
\text { skilled agricultural } \\
\text { occupation }\end{array}$ & 0.93 & 0.85 & 0.08 & 0.02 & 0.00 & 615 & 472 \\
\hline $\begin{array}{l}\text { Dummy for } \\
\text { unskilled occup. }\end{array}$ & 0.03 & 0.07 & -0.04 & 0.01 & 0.00 & 615 & 472 \\
\hline $\begin{array}{l}\text { Hours worked per } \\
\text { week }\end{array}$ & 50.78 & 41.50 & 9.28 & 0.95 & 0.00 & 615 & 471 \\
\hline
\end{tabular}

Source: TLSS 2007 
Table A8: All female individuals in cotton (treated) vs. female in non-cotton regions (control) in 2007

\begin{tabular}{|c|c|c|c|c|c|c|c|}
\hline Variable & $\begin{array}{l}\text { Mean } \\
\text { Control } \\
\text { Group }\end{array}$ & $\begin{array}{l}\text { Mean } \\
\text { Treated } \\
\text { Group }\end{array}$ & Difference & $\begin{array}{c}\text { SE of } \\
\text { Difference }\end{array}$ & P-value & $\begin{array}{c}\mathbf{N} \\
\text { Control }\end{array}$ & $\begin{array}{c}\mathbf{N} \\
\text { Treated }\end{array}$ \\
\hline Wage & 127.87 & 154.02 & -26.16 & 14.24 & 0.07 & 356 & 1099 \\
\hline $\begin{array}{l}\text { Dummy working } \\
\text { in agriculture } \\
\text { (working age } \\
\text { population) }\end{array}$ & 0.17 & 0.19 & -0.02 & 0.01 & 0.12 & 2313 & 3617 \\
\hline $\begin{array}{l}\text { Dummy working } \\
\text { in agriculture } \\
\text { (female children } \\
\text { below 18) }\end{array}$ & 0.02 & 0.03 & -0.01 & 0.00 & 0.22 & 1509 & 2481 \\
\hline Age & 26.23 & 25.52 & 0.71 & 0.39 & 0.07 & 3786 & 6029 \\
\hline $\begin{array}{l}\text { Dummy for } \\
\text { primary or no } \\
\text { education }\end{array}$ & 0.60 & 0.58 & 0.02 & 0.01 & 0.03 & 3786 & 6029 \\
\hline $\begin{array}{l}\text { Dummy for } \\
\text { secondary educ. }\end{array}$ & 0.37 & 0.37 & 0.00 & 0.01 & 0.87 & 3786 & 6029 \\
\hline $\begin{array}{l}\text { Dummy for } \\
\text { tertiary educ. }\end{array}$ & 0.02 & 0.05 & -0.02 & 0.00 & 0.00 & 3786 & 6029 \\
\hline $\begin{array}{l}\text { Dummy for } \\
\text { working in a } \\
\text { small firm ( } \leq 25 \\
\text { employees) }\end{array}$ & 0.13 & 0.10 & 0.03 & 0.01 & 0.00 & 3786 & 6029 \\
\hline $\begin{array}{l}\text { Dummy for } \\
\text { working in a very } \\
\text { large firm (>50 } \\
\text { employees) }\end{array}$ & 0.02 & 0.06 & -0.04 & 0.00 & 0.00 & 3786 & 6029 \\
\hline $\begin{array}{l}\text { Dummy for high } \\
\text { occupation }\end{array}$ & 0.03 & 0.05 & -0.01 & 0.00 & 0.00 & 3786 & 6029 \\
\hline $\begin{array}{l}\text { Dummy for occ. } \\
\text { group } 4,5,7 \text { and } 8\end{array}$ & 0.02 & 0.04 & -0.02 & 0.00 & 0.00 & 3786 & 6029 \\
\hline $\begin{array}{l}\text { Dummy for } \\
\text { skilled } \\
\text { agricultural } \\
\text { occupation }\end{array}$ & 0.10 & 0.11 & -0.01 & 0.01 & 0.03 & 3786 & 6029 \\
\hline $\begin{array}{l}\text { Dummy for } \\
\text { unskilled occup. }\end{array}$ & 0.02 & 0.02 & 0.00 & 0.00 & 0.73 & 3786 & 6029 \\
\hline $\begin{array}{l}\text { Hours worked } \\
\text { per week }\end{array}$ & 38.15 & 42.74 & -4.58 & 0.81 & 0.00 & 642 & 1284 \\
\hline
\end{tabular}


Table A9: Net profits on small vs. large farms in Tajik Somoni

\begin{tabular}{|c|c|c|c|c|}
\hline & $\begin{array}{r}\text { Grou } \\
\text { (SE in I }\end{array}$ & $\begin{array}{l}\text { Ieans } \\
\text { nthesis) }\end{array}$ & $\begin{array}{l}\text { Difference } \\
\text { (Large- }\end{array}$ & $\begin{array}{l}\text { p-value of the } \\
\text { T-Test }\end{array}$ \\
\hline & $\begin{array}{l}\text { Small Farms } \\
(<20 \text { ha })\end{array}$ & $\begin{array}{l}\text { Large } \\
\text { Farms (>20 } \\
\text { ha) }\end{array}$ & & \\
\hline Net profits per farm in USD & $\begin{array}{l}1765.87 \\
(336.37)\end{array}$ & $\begin{array}{l}60732.93 \\
(29978.71)\end{array}$ & $\begin{array}{l}58967.05 \\
(39665.08)\end{array}$ & 0.07 \\
\hline Number of observations & 47 & 82 & & \\
\hline
\end{tabular}


Table A10: Sub-samples (agricultural vs. non-agricultural workers) for Table 2

\begin{tabular}{|c|c|c|c|c|c|c|}
\hline \multirow[b]{4}{*}{ Dependent variable } & \multirow{2}{*}{\multicolumn{3}{|c|}{$\begin{array}{l}(1) \\
\text { Agricultural workers }\end{array}$}} & (4) & (5) & (6) \\
\hline & & & & \multicolumn{3}{|c|}{ Non-agricultural workers } \\
\hline & $\begin{array}{c}\text { Full } \\
\text { sample }\end{array}$ & Male & Female & $\begin{array}{c}\text { Full } \\
\text { sample }\end{array}$ & Male & Female \\
\hline & \multicolumn{6}{|c|}{ Log of the real wage per hour } \\
\hline \multirow[t]{2}{*}{ CottonPSU*year2009 } & -0.14 & -0.26 & -0.18 & 0.06 & 0.01 & 0.14 \\
\hline & $(0.24)$ & $(0.30)$ & $(0.29)$ & $(0.09)$ & $(0.10)$ & $(0.14)$ \\
\hline \multirow[t]{2}{*}{ CottonPSU*year2011 } & 0.17 & -0.13 & $0.39 * *$ & -0.13 & -0.11 & -0.16 \\
\hline & $(0.20)$ & $(0.25)$ & $(0.18)$ & $(0.10)$ & $(0.10)$ & $(0.17)$ \\
\hline \multirow[t]{2}{*}{ Female } & $-0.13 * * *$ & & & $-0.43 * * *$ & & \\
\hline & $(0.04)$ & & & $(0.03)$ & & \\
\hline \multirow[t]{2}{*}{ Age } & $0.01 * * *$ & 0.00 & $0.01 * * *$ & -0.00 & -0.00 & -0.00 \\
\hline & $(0.00)$ & $(0.00)$ & $(0.00)$ & $(0.00)$ & $(0.00)$ & $(0.00)$ \\
\hline \multirow[t]{2}{*}{ Secondary educ. } & 0.02 & 0.01 & 0.01 & $0.18 * * *$ & $0.23 * * *$ & 0.01 \\
\hline & $(0.05)$ & $(0.08)$ & $(0.06)$ & $(0.05)$ & $(0.07)$ & $(0.08)$ \\
\hline \multirow[t]{2}{*}{ Tertiary educ. } & $0.24 *$ & $0.27 *$ & -0.15 & $0.43 * * *$ & $0.37 * * *$ & $0.47 * * *$ \\
\hline & $(0.13)$ & $(0.15)$ & $(0.28)$ & $(0.06)$ & $(0.07)$ & $(0.10)$ \\
\hline \multirow[t]{2}{*}{ Large firm } & $-0.18 * *$ & -0.16 & $-0.17 *$ & $0.20 * * *$ & $0.24 * * *$ & $0.12 * *$ \\
\hline & $(0.09)$ & $(0.10)$ & $(0.10)$ & $(0.04)$ & $(0.05)$ & $(0.06)$ \\
\hline \multirow[t]{2}{*}{ State firm } & $-0.21 * * *$ & -0.12 & $-0.32 * * *$ & $-0.54 * * *$ & $-0.51 * * *$ & $-0.46 * * *$ \\
\hline & $(0.08)$ & $(0.10)$ & $(0.09)$ & $(0.04)$ & $(0.05)$ & $(0.08)$ \\
\hline \multirow[t]{2}{*}{ Occ. high } & $0.21 *$ & 0.13 & 0.12 & $0.12 * *$ & 0.07 & $0.23 * *$ \\
\hline & $(0.12)$ & $(0.15)$ & $(0.31)$ & $(0.05)$ & $(0.06)$ & (0.09) \\
\hline \multirow[t]{2}{*}{ Occ. middle } & $0.40 * *$ & 0.28 & 0.26 & $0.15 * * *$ & 0.07 & $0.33 * * *$ \\
\hline & $(0.15)$ & $(0.18)$ & $(0.46)$ & $(0.04)$ & $(0.05)$ & $(0.11)$ \\
\hline \multirow[t]{2}{*}{ Occ. skilled agric. } & -0.04 & -0.18 & 0.05 & $-0.52 * * *$ & $-0.57 * * *$ & -0.25 \\
\hline & $(0.09)$ & $(0.12)$ & $(0.13)$ & $(0.20)$ & $(0.17)$ & $(0.49)$ \\
\hline \multirow[t]{2}{*}{ Constant } & 0.11 & $-1.97 *$ & $-1.64 * * *$ & $0.23 * *$ & 0.12 & -0.05 \\
\hline & $(0.88)$ & $(1.05)$ & $(0.23)$ & $(0.12)$ & $(0.14)$ & $(0.21)$ \\
\hline Observations & 2,109 & 982 & 1,127 & 4,693 & 3,426 & 1,267 \\
\hline R-squared & 0.36 & 0.33 & 0.42 & 0.27 & 0.20 & 0.32 \\
\hline Adjusted R-squared & 0.340 & 0.284 & 0.390 & 0.258 & 0.186 & 0.271 \\
\hline \multicolumn{7}{|c|}{$\begin{array}{l}\text { Note: The dependent variable is the log of the real wage per hour in the last month. Columns } 1-3 \text { only include individuals that work in } \\
\text { agriculture (column } 1 \text { refers to the full sample, whereas column } 2 \text { and } 3 \text { show results for the male and female sub-samples, respectively), } \\
\text { whereas columns } 4-6 \text { show results for individuals that work in non-agricultural activities (column } 4 \text { refers to the full sample, whereas column } \\
5 \text { and } 6 \text { show results for the male and female sub-samples, respectively). All specifications are estimated using OLS and include district } \\
\text { dummies, province-year dummies, dummies for the month of the interview as well as dummies for cotton PSU, the year of the interview as } \\
\text { well as all interactions of cotton PSU and the year dummies. Robust standard errors (clustered at the PSU level) in parentheses } * * * \text { p }<0.01 \text {, } \\
* * \text { p }<0.05, * \text { p }<0.1 \text { Source: TLSS 2007-11. }\end{array}$} \\
\hline
\end{tabular}


Table A11: Sub-samples (agricultural vs. non-agricultural workers) for Table 3

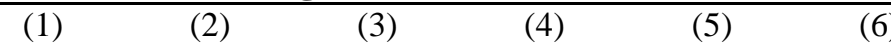

Large firms ( $>25$ employees) Small firms ( $<=\leq 25$ employees)

Full
sample $\quad$ Male Female $\begin{gathered}\text { Full } \\ \text { sample }\end{gathered}$ Male Female

Dependent variable
Log of the real wage per hour

\section{Agricultural workers}

$\begin{array}{lcccccc}\text { CottonPSU*year2009 } & -0.11 & -0.09 & -0.12 & -0.19 & -0.40 & -0.00 \\ & (0.21) & (0.26) & (0.22) & (0.32) & (0.41) & (0.33) \\ \text { CottonPSU*year2011 } & -0.14 & -0.12 & -0.14 & 0.05 & -0.34 & 0.57 * * \\ & (0.17) & (0.21) & (0.31) & (0.25) & (0.33) & (0.25) \\ & & & & & & \\ \text { Observations } & 1,083 & 429 & 654 & 1,026 & 553 & 473 \\ \text { R-squared } & 0.35 & 0.39 & 0.37 & 0.38 & 0.34 & 0.52 \\ \text { Adjusted R-squared } & 0.313 & 0.287 & 0.314 & 0.332 & 0.245 & 0.448\end{array}$

\begin{tabular}{lccccccc}
\multicolumn{7}{c}{ Non-agricultural workers } \\
\hline CottonPSU*year2009 & 0.10 & 0.09 & 0.03 & -0.01 & -0.04 & 0.06 \\
& $(0.15)$ & $(0.18)$ & $(0.22)$ & $(0.12)$ & $(0.13)$ & $(0.24)$ \\
CottonPSU*year2011 & -0.09 & -0.09 & -0.10 & -0.10 & -0.05 & -0.43 \\
& $(0.13)$ & $(0.15)$ & $(0.21)$ & $(0.12)$ & $(0.12)$ & $(0.32)$ \\
& & & & & & \\
& & & & & & \\
& 1,901 & 1,277 & 624 & 2,792 & 2,149 & 643 \\
Rbservations & 0.33 & 0.27 & 0.37 & 0.27 & 0.21 & 0.36 \\
Adjusted R-squared & 0.296 & 0.225 & 0.286 & 0.251 & 0.182 & 0.274 \\
\hline
\end{tabular}

Note: The dependent variable is the log of the real wage per hour in the last month. In the upper panel, we only include individuals that work in agriculture, whereas the lower panel shows results for individuals that work in non-agricultural activities. Columns 1-3 only include individuals that work in firms with more than 25 employees (column 1 refers to the full sample, whereas column 2 and 3 show results for the male and female sub-samples, respectively), whereas columns 4-6 show results for individuals that work in firms with at most 25 employees (column 4 refers to the full sample, whereas column 5 and 6 show results for the male and female sub-samples, respectively). All specifications are estimated using OLS and include district dummies, province-year dummies, dummies for the month of the interview as well as dummies for cotton PSU, the year of the interview and all interactions of cotton PSU and the year dummies. The individual controls shown in Table 2, i.e., sex, age, dummies for the education and occupation of the individual as well as for working in a very large firm or in a state firm, are also included in all specifications, but are not shown in the table. Robust standard errors (clustered at the PSU level) in parentheses $* * * \mathrm{p}<0.01, * * \mathrm{p}<0.05, * \mathrm{p}<0.1$ Source: TLSS 2007-11. 


$\begin{array}{ccccc}(1) & (2) & (3) & (4) & (5) \\ \text { Large firms } & & \text { Small firms } & \\ >25 & >50 & <=16 & \leq 25 & <=50 \\ \text { employe } & \text { employe } & \text { employe } & \text { employe } & \text { employe } \\ \text { es } & \text { es } & \text { es } & \text { es } & \text { es }\end{array}$

Dependent variable
Log of the real wage per hour

\section{OLS}

$\begin{array}{lccccc}\text { CottonPSU*year2009*Agri } & -0.30 & -0.16 & 0.02 & -0.01 & -0.14 \\ & (0.31) & (0.45) & (0.55) & (0.38) & (0.42) \\ \text { CottonPSU*year2011*Agri } & -0.10 & 0.38 & 1.45 * * * & 1.10 * * * & 0.74 * * \\ & (0.35) & (0.41) & (0.51) & (0.35) & (0.28) \\ & & & & & \\ & 1,278 & 708 & 714 & 1,116 & 1,686 \\ \text { Observations } & 0.51 & 0.55 & 0.37 & 0.38 & 0.39 \\ \text { R-squared } & 0.473 & 0.501 & 0.284 & 0.335 & 0.360\end{array}$

\section{Fixed Effects}

\begin{tabular}{|c|c|c|c|c|c|}
\hline CottonPSU*year2009*Agri & $\begin{array}{c}0.13 \\
(0.28)\end{array}$ & $\begin{array}{c}0.42 \\
(0.78)\end{array}$ & $\begin{array}{c}0.90 \\
(0.77)\end{array}$ & $\begin{array}{c}0.94 \\
(0.73)\end{array}$ & $\begin{array}{c}0.58 \\
(0.43)\end{array}$ \\
\hline CottonPSU*year2011*Agri & $\begin{array}{l}-0.64 \\
(0.46)\end{array}$ & $\begin{array}{l}-0.62 \\
(0.83)\end{array}$ & $\begin{array}{c}3.24 * * \\
(1.54)\end{array}$ & $\begin{array}{c}1.90 * * * \\
(0.65)\end{array}$ & $\begin{array}{c}1.31 * * * \\
(0.43)\end{array}$ \\
\hline Individual FE & Yes & Yes & Yes & Yes & Yes \\
\hline Observations & 1,278 & 708 & 714 & 1,116 & 1,686 \\
\hline R-squared & 0.39 & 0.62 & 0.42 & 0.34 & 0.35 \\
\hline Adjusted R-squared & 0.376 & 0.608 & 0.397 & 0.323 & 0.341 \\
\hline
\end{tabular}

Note: The dependent variable is the log of the real wage per hour in the last month. In the upper panel, we estimate all specification using simple OLS, whereas the lower panel shows results for the estimation using individual fixed effects. All specifications exclusively include female workers. Columns 1-2 only include women that work in large firms, whereas in column 1 large firms are defined having more than 25 employees and in column 2 as having more than 50 employees. Columns 4-6 show results for women that work in small firms, whereas in column 3 small firms are defined as having less than/equal 16 employees, in column 4 as having at most 25 employees and in column 5 as having less than/equal 50 employees. All specifications include district dummies, province-year dummies, dummies for the month of the interview as well as dummies for cotton PSU, the year of the interview and a dummy for working in agriculture (agri) as well as all interactions of cotton PSU, the year dummies and the agri dummy. The individual controls shown in Table 2, i.e., sex, age, dummies for the education and occupation of the individual as well as for working in a very large firm or in a state firm, are also included in all specifications, but are not shown in the table. Robust standard errors (clustered at the PSU level) in parentheses $* * * \mathrm{p}<0.01, * * \mathrm{p}<0.05, * \mathrm{p}<0.1$ Source: TLSS 2007-11. 
Table A13: Including in-kind payments in the wage measure

$\begin{array}{cccccccc}(1) & \begin{array}{c}(2) \\ \text { All workers }\end{array} & (3) & \begin{array}{c}(4) \\ \text { Large firms }(>25 \\ \text { employees) }\end{array} & \begin{array}{c}(7) \\ \text { Small firms }(\leq 25 \\ \text { employees })\end{array} \\ \begin{array}{c}\text { Full } \\ \text { sample }\end{array} & \text { Male } & \text { Female } & \begin{array}{c}\text { Full } \\ \text { sample }\end{array} & \begin{array}{c}\text { Male } \\ \text { Male }\end{array} & \text { Female } & \begin{array}{c}\text { Full } \\ \text { Fample }\end{array} & \text { Female }\end{array}$

Dependent variable

Log of wages and in kind payments per hour

$\begin{array}{lccccccccc}\text { CottonPSU*year2009*Agri } & 0.03 & -0.04 & 0.09 & -0.15 & -0.55 & 0.22 & 0.12 & 0.09 & 0.12 \\ & (0.22) & (0.29) & (0.33) & (0.33) & (0.34) & (0.39) & (0.28) & (0.35) & (0.37) \\ \text { CottonPSU*year2011*Agri } & 0.44^{*} & 0.18 & 0.67 * * & -0.14 & -0.20 & 0.01 & 0.45 & 0.12 & 1.11^{* * *} \\ & (0.24) & (0.29) & (0.27) & (0.25) & (0.37) & (0.38) & (0.29) & (0.32) & (0.41) \\ & & & & & & & & \\ \text { Observations } & 7,173 & 4,622 & 2,551 & 3,022 & 1,721 & 1,301 & 4,151 & 2,901 & 1,250 \\ \text { R-squared } & 0.38 & 0.33 & 0.37 & 0.51 & 0.46 & 0.49 & 0.32 & 0.30 & 0.34 \\ \text { Adjusted R-squared } & 0.373 & 0.322 & 0.345 & 0.493 & 0.436 & 0.453 & 0.307 & 0.275 & 0.290\end{array}$

\section{Dependent variable}

\begin{tabular}{lccccccccc} 
CottonPSU*year2009*Agri & -0.08 & -0.10 & -0.05 & -0.17 & -0.39 & 0.11 & -0.09 & -0.11 & -0.15 \\
& $(0.19)$ & $(0.25)$ & $(0.30)$ & $(0.29)$ & $(0.31)$ & $(0.36)$ & $(0.25)$ & $(0.31)$ & $(0.35)$ \\
CottonPSU*year2011*Agri & 0.26 & 0.07 & $0.55^{*}$ & -0.09 & -0.17 & 0.17 & 0.16 & -0.11 & $0.87 * *$ \\
& $(0.24)$ & $(0.28)$ & $(0.30)$ & $(0.22)$ & $(0.32)$ & $(0.36)$ & $(0.27)$ & $(0.31)$ & $(0.39)$ \\
& & & & & & & & & \\
Observations & 7,236 & 4,661 & 2,575 & 3,048 & 1,738 & 1,310 & 4,188 & 2,923 & 1,265 \\
R-squared & 0.43 & 0.37 & 0.36 & 0.52 & 0.47 & 0.47 & 0.41 & 0.36 & 0.36 \\
Adjusted R-squared & 0.424 & 0.357 & 0.335 & 0.508 & 0.444 & 0.430 & 0.403 & 0.339 & 0.317 \\
\hline
\end{tabular}

Note: In the upper panel, the dependent variable is the log of the real wage (including all in kind payments) per hour in the last month. The lower panel shows results for the dependent variable log of the real wage (including all in kind payments) in the last month. In kind payments are reported in the TLSS survey for the last year and we compute a monthly average to be able to combine this information with the monetary harvest wage information. Column 1-3 show results for all workers, whereby column 1 refers to the full sample, whereas column 2 and 3 show results for the male and female sub-samples, respectively. Columns 4-6 only include individuals that work in firms with more than 25 employees, whereby column 4 refers to the full sample, whereas column 5 and 6 show results for the male and female sub-samples, respectively. Columns 7-9 show results for individuals that work in firms with at most 25 employees, whereby column 7 refers to the full sample, whereas column 8 and 9 show results for the male and female sub-samples, respectively. All specifications are estimated using OLS and include district dummies, province-year dummies, dummies for the month of the interview as well as dummies for cotton PSU, the year of the interview and a dummy for working in agriculture (agri) as well as all interactions of cotton PSU, the year dummies and the agri dummy. The individual controls shown in Table 2, i.e., sex, age, dummies for the education and occupation of the individual as well as for working in a very large firm or in a state firm, are also included in all specifications, but are not shown in the table. Robust standard errors (clustered at the PSU level) in parentheses *** $\mathrm{p}<0.01, * * \mathrm{p}<0.05, * \mathrm{p}<0.1$ Source: TLSS 2007-11. 
Table A14: Monthly earnings

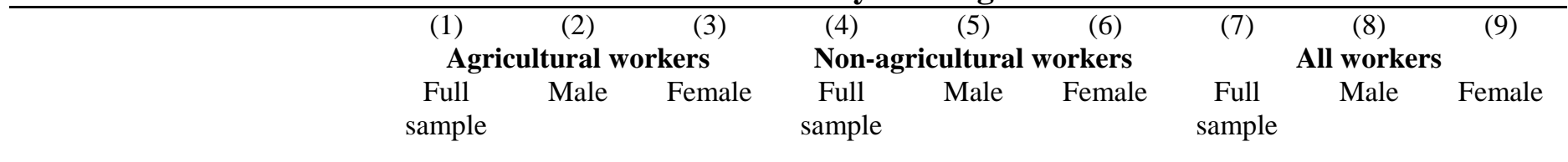

Log of the real monthly earnings

\section{Dependent variable}

CottonPSU*year2009

CottonPSU*year2011

CottonPSU*year2009*Agri

CottonPSU*year2011*Agri

Female

$-0.23 * * *$

(0.03)

Age

Secondary educ.

$0.01 * * *$

$(0.00)$

0.03

$(0.05)$

$0.28 * *$

(0.11)

$-0.07$

(0.08)

$-0.17 * *$

(0.07)

$0.20 *$

(0.11)

$0.34 * *$

(0.14)

$-0.05$

(0.08)

$5.29 * * *$

(1.18)

2,116

0.28

0.253

Occ. skilled agric.

Observations

R-squared
$-0.19$

(0.22)

$-0.07$

(0.21)

$-0.26$

$(0.28)$

0.14

$(0.25)$

0.04

(0.10)

0.01

$-0.12$

(0.10)

0.06

$-0.08$

(0.15)

(0.10)

(0.10)

$-0.30 *$

(0.17)

0.10

(0.10)

0.02

0.10

$-0.12$

(0.11)

(0.14)

(0.10)

$-0.12$

-0.27 *

$-0.21$

$(0.10)$

(0.17)

(0.24)

$-0.23$

0.16

(0.26)

(0.32)

(0.20)

0.03

0.43

$-0.48^{* * * *}$

(0.22)

(0.30)

(0.02)

(0.03)

$0.00 \quad 0.01 * * *$

$-0.00 * *$

$-0.00 * * *$

0.00

$-0.00$

(0.00)

$(0.00) \quad(0.00)$

$\begin{array}{ll}(0.00) & (0.00) \\ -0.03 & 0.05\end{array}$

(0.00)

$0.19 * * *$

(0.00)

$\quad(0.00)$

(0.08)

$(0.05)$

$0.33^{* *}$

$-0.43^{*}$

(0.04)

$.21 * * *$

0.05

$0.11 * * *$

$0.00 * * *$

(0.13) (0.26)

$0.40 * * *$

$0.34 * * *$

(0.06)

(0.03)

$0.34 * * *$

(0.00)

$(0.00)$

$(0.05)$

$0.34 * * *$

$0.46 * * *$

$(0.05)$

0.07

$-0.08$

$-0.06$

$0.27 * * *$

$\quad(0.08)$

(0.04)

$0.29 * * *$

(0.04)

(0.10)

(0.09)

(0.03)

$0.31 * * *$

$0.18 * * *$

$0.14 * * *$

(0.05)

0.41 ***

$-0.10$

$-0.28 * * *$

$-0.56 * * *$

(0.04)

$0.21 * * *$

(0.07)

$(0.09)$

(0.08)

(0.03)

$-0.50 * * *$

$-0.52 * * *$

$-0.45 * * *$

(0.04)

0.02

0.05

$0.63 * *$

$0.09 *$

(0.04)

$(0.07)$

(0.04)

$0.10^{* *}$

$-0.41 * * *$

(0.06)

(0.13)

$(0.28)$

(0.05)

$-0.03$

$0.32 * * *$

(0.04)

$-0.01$

$-0.39 * *$

$0.26 *$

$-0.18$

$0.22 * * *$

$0.11 * *$

(0.08)

(0.05)

(0.05)

(0.05)

(0.15)

(0.32)

$-0.19 * *$

(0.04)

0.08

(0.04)

$0.49 * * *$

$0.29 * * *$

$0.16 * * *$

(0.09)

(0.12)

$-0.45^{* * *}$

$-0.58 * * *$

(0.09)

(0.04)

(0.04)

$0.53 * * *$

$3.37 * * * \quad 4.24 * * *$

$5.52 * * *$

(0.16)

0.04

$-0.11^{*}$

$-0.32 * * *$

$(0.09)$

$5.52 * * *$

$5.54 * * *$

(0.40)

(0.06)

(0.07)

0.09

(0.26)

(0.11)

(0.12)

$(0.20)$

$5.44 * * *$

$5.48 * * *$

(0.10)

$4.57 * * *$

(0.10)

(0.12)

(0.17)

983

1,133

4,743

3,461

0.35

0.24

1,282

0.40

6,859

0.44

4,444

0.36

2,415

0.234

0.339

0.220

0.360

0.437

0.351

0.39

0.370

Note: The dependent variable is the log of the real wage in the last month. Column 1-3 show results for agricultural workers, whereby column 1 refers to the full sample, whereas column 2 and 3 show results for the male and female sub-samples, respectively. Columns 4-6 only include individuals that work in non-agricultural activities, whereby column 4 refers to the full sample, whereas column 5 and 6 show results for the male and female sub-samples, respectively. Columns 7-9 show results for all working individuals, whereby column 7 refers to the full sample, whereas column 8 and 9 show results for the male and female sub-samples, respectively. All specifications are estimated using OLS and include district dummies, province-year dummies, dummies for the month of the interview as well as dummies for cotton PSU, the year of the interview and a dummy for working in agriculture (agri) as well as all interactions of cotton PSU, the year dummies and the agri dummy. Robust standard errors (clustered at the PSU level) in parentheses $* * * \mathrm{p}<0.01, * * \mathrm{p}<0.05, * \mathrm{p}<0.1$ Source: TLSS $2007-11$. 
Table A15: FE estimation for Table 2

\begin{tabular}{|c|c|c|c|c|c|c|}
\hline & \multirow{2}{*}{\multicolumn{3}{|c|}{ Working age population }} & (4) & (5) & (6) \\
\hline & & & & \multicolumn{3}{|c|}{ Working population (employees) } \\
\hline & $\begin{array}{c}\text { Full } \\
\text { sample }\end{array}$ & Male & Female & $\begin{array}{c}\text { Full } \\
\text { sample }\end{array}$ & Male & Female \\
\hline Dependent variable & \multicolumn{3}{|c|}{ Working in agriculture } & \multicolumn{3}{|c|}{ Log of the real wage per hour } \\
\hline \multirow[t]{2}{*}{ CottonPSU*year2009 } & 0.02 & 0.02 & 0.02 & 0.07 & 0.04 & 0.07 \\
\hline & $(0.05)$ & $(0.05)$ & $(0.06)$ & $(0.11)$ & $(0.14)$ & $(0.18)$ \\
\hline \multirow{2}{*}{ CottonPSU*year2011 } & $0.09 *$ & 0.07 & $0.12 *$ & $-0.20 *$ & -0.18 & $-0.33 *$ \\
\hline & $(0.05)$ & $(0.06)$ & $(0.06)$ & $(0.12)$ & $(0.13)$ & $(0.18)$ \\
\hline \multirow{2}{*}{ CottonPSU*year2009*Agri } & & & & -0.39 & -0.61 & 0.17 \\
\hline & & & & $(0.46)$ & $(0.53)$ & $(0.37)$ \\
\hline \multirow[t]{2}{*}{ CottonPSU*year2011*Agri } & & & & 0.29 & -0.15 & $0.97 * * *$ \\
\hline & & & & $(0.35)$ & $(0.44)$ & $(0.29)$ \\
\hline \multirow[t]{2}{*}{ Female } & 0.01 & 0.01 & 0.01 & -0.02 & -0.04 & -0.01 \\
\hline & $(0.00)$ & $(0.01)$ & $(0.01)$ & $(0.02)$ & $(0.02)$ & $(0.03)$ \\
\hline \multirow[t]{2}{*}{ Age } & -0.01 & 0.02 & -0.03 & -0.00 & 0.04 & -0.09 \\
\hline & $(0.01)$ & $(0.02)$ & $(0.02)$ & $(0.08)$ & $(0.12)$ & $(0.10)$ \\
\hline \multirow[t]{2}{*}{ Secondary educ. } & -0.01 & 0.04 & $-0.08 * * *$ & -0.06 & -0.03 & -0.02 \\
\hline & $(0.02)$ & $(0.03)$ & $(0.03)$ & $(0.10)$ & $(0.13)$ & $(0.15)$ \\
\hline \multirow[t]{2}{*}{ Tertiary educ. } & & & & -0.01 & 0.04 & -0.06 \\
\hline & & & & $(0.05)$ & $(0.06)$ & $(0.07)$ \\
\hline \multirow[t]{2}{*}{ Large firm } & & & & $-0.13^{* *}$ & -0.12 & -0.18 \\
\hline & & & & $(0.06)$ & $(0.08)$ & $(0.11)$ \\
\hline \multirow{2}{*}{ State firm } & & & & 0.16 & 0.05 & 0.32 \\
\hline & & & & $(0.10)$ & $(0.12)$ & $(0.20)$ \\
\hline \multirow[t]{2}{*}{ Occ. high } & & & & $0.20 * *$ & 0.16 & 0.15 \\
\hline & & & & $(0.09)$ & $(0.10)$ & $(0.17)$ \\
\hline \multirow[t]{2}{*}{ Occ. middle } & & & & -0.18 & $-0.42 * * *$ & 0.23 \\
\hline & & & & $(0.11)$ & $(0.15)$ & $(0.14)$ \\
\hline \multirow[t]{2}{*}{ Constant } & -0.05 & -0.06 & -0.04 & 0.94 & $1.56^{*}$ & -0.16 \\
\hline & $(0.14)$ & $(0.23)$ & $(0.17)$ & $(0.67)$ & $(0.86)$ & $(0.87)$ \\
\hline Individual FE & Yes & Yes & Yes & Yes & Yes & Yes \\
\hline Observations & 16,456 & 7,865 & 8,591 & 6,802 & 4,408 & 2,394 \\
\hline R-squared & 0.02 & 0.03 & 0.02 & 0.24 & 0.25 & 0.32 \\
\hline Adjusted R-squared & 0.0166 & 0.0295 & 0.0178 & 0.239 & 0.244 & 0.309 \\
\hline \multicolumn{7}{|c|}{$\begin{array}{l}\text { Note: In columns 1-3, the dependent variable is an indicator whether the person works in agriculture or not, whereby we use the full sample } \\
\text { of the working age population (column } 1 \text { refers to the full sample, whereas column } 2 \text { and } 3 \text { show results for the male and female sub- } \\
\text { samples, respectively). In columns } 4-6 \text {, the dependent variable is the log of the real wage per hour in the last month and the specifications are } \\
\text { estimated for all workers (column } 4 \text { refers to the full sample, whereas column } 5 \text { and } 6 \text { show results for the male and female sub-samples, } \\
\text { respectively). All specifications are estimated using individual fixed effects estimation and include district dummies, province-year dummies, } \\
\text { dummies for the month of the interview as well as dummies for cotton PSU and the year of the interview. Columns } 4-6 \text { additionally include a } \\
\text { dummy for working in agriculture (agri) and its interactions with cotton PSU and the year dummies. Columns } 1-3 \text { include additional control } \\
\text { variables at the individual, PSU and sub-district level. Individual controls are available from the TLSS for each year of the sample and } \\
\text { comprise dummies for the ethnicity and the marital status of the individual as well as household size. PSU level controls are for the year } \\
2007 \text { and include the distance of the PSU to the province capital, a dummy for urban location as well as measures for the importance of } \\
\text { agriculture and male unemployment in the PSU. Sub-district level control variables come from the World Bank Socio-Economic Atlas of } \\
\text { Tajikistan (2005) and refer either to the year } 2003 \text { or the year } 2000 \text {. They comprise the unemployment rate, the dependency ratio, the share } \\
\text { of the economically active (female) population, the share of households living below the poverty line, the log of the population density, the } \\
\text { share of individuals with primary education completed and the share with secondary education completed, the share of households with } \\
\text { electrical power supply in the dwelling as well as the share of households with a landline phone. Robust standard errors (clustered at the PSU } \\
\text { level) in parentheses } * * * \text { p }<0.01, * * \text { p }<0.05, * \text { p }<0.1 \text { Source: TLSS } 2007-11 \text {. }\end{array}$} \\
\hline
\end{tabular}


Table A16: FE estimation for Table 3

\begin{tabular}{|c|c|c|c|c|c|}
\hline (1) & (2) & (3) & (4) & (5) & (6) \\
\hline \multicolumn{3}{|c|}{ Large firms (>25 employees) } & \multicolumn{3}{|c|}{ Small firms ( $\leq 25$ employees) } \\
\hline $\begin{array}{c}\text { Full } \\
\text { sample }\end{array}$ & Male & Female & $\begin{array}{r}\text { Full } \\
\text { sampl }\end{array}$ & Male & Female \\
\hline
\end{tabular}

Dependent variable

Log of the real wage per hour

$\begin{array}{lcccccc}\text { CottonPSU*year2009*Agri } & -0.20 & -0.54 & 0.13 & -0.66 & -1.11 & 0.94 \\ & (0.35) & (0.48) & (0.28) & (0.80) & (0.89) & (0.73) \\ \text { CottonPSU*year2011*Agri } & -0.03 & -0.17 & -0.64 & -0.02 & -0.67 & 1.90 * * * \\ & (0.38) & (0.46) & (0.46) & (0.65) & (0.78) & (0.65) \\ & & & & & & \text { Yes } \\ \text { Individual FE } & \text { Yes } & \text { Yes } & \text { Yes } & \text { Yes } & \text { Yes } & \text { Yes } \\ \text { Observations } & 2,984 & 1,706 & 1,278 & 3,818 & 2,702 & 1,116 \\ \text { R-squared } & 0.38 & 0.45 & 0.39 & 0.20 & 0.20 & 0.34 \\ \text { Adjusted R-squared } & 0.375 & 0.435 & 0.376 & 0.192 & 0.193 & 0.323\end{array}$

\section{Dependent variable}

CottonPSU*year2009*Agri

CottonPSU*year2011*Agri

\section{$-0.21$}

(0.32)

0.09

(0.41)

Yes

3,009

0.36

0.355

Individual FE

Observations

R-squared

Adjusted R-squared

Log of the real monthly wage

$\begin{array}{ccccc}-0.33 & 0.06 & -0.62 & -1.01 & 0.42 \\ (0.44) & (0.26) & (0.56) & (0.63) & (0.57) \\ 0.05 & -0.88 * * & -0.14 & -0.66 & 1.53 * * * \\ (0.49) & (0.43) & (0.45) & (0.54) & (0.50) \\ & & & & \\ \text { Yes } & \text { Yes } & \text { Yes } & \text { Yes } & \text { Yes } \\ 1,723 & 1,286 & 3,850 & 2,721 & 1,129 \\ 0.43 & 0.38 & 0.24 & 0.25 & 0.47 \\ 0.424 & 0.365 & 0.237 & 0.238 & 0.462\end{array}$

Yes

47 0.462 endent variable $\log$ of the real wage in the last month. Columns 1-3 only include individuals that work in firms with more than 25 employees (column 1 refers to the full sample, whereas column 2 and 3 show results for the male and female sub-samples, respectively), whereas columns 4-6 show results for individuals that work in firms with at most 25 employees (column 4 refers to the full sample, whereas column 5 and 6 show results for the male and female sub-samples, respectively). All specifications are estimated using individual fixed effects estimation and include district dummies, province-year dummies, dummies for the month of the interview as well as dummies for cotton PSU, the year of the interview and a dummy for working in agriculture (agri) as well as all interactions of cotton PSU, the year dummies and the agri dummy. The individual controls shown in Table 3, i.e., sex, age, dummies for the education and occupation of the individual as well as for working in a very large firm or in a state firm, are also included in all specifications, but are not shown in the table. Robust standard errors (clustered at the PSU level) in parentheses *** $\mathrm{p}<0.01, * * \mathrm{p}<0.05$, * $\mathrm{p}<0.1$ Source: TLSS 2007-11. 
Table A17: FE estimation for Table 4

(1) (2)

Yearly prices Sowing period prices Harvest period prices

Dependent variable

Log of the real wage per hour

$\begin{array}{lccc}\text { Lnprice*agri*cottonPSU } & 1.10^{* * *} & 0.77 * * * & 1.62 * * * \\ & (0.37) & (0.26) & (0.54) \\ \text { Lnprice } & 1.06^{* * *} & 0.54 * * * & 0.82^{* * *} \\ & (0.27) & (0.17) & (0.34) \\ \text { Lnprice*cottonPSU } & -0.59^{* *} & -0.21 & -0.09 \\ & (0.25) & (0.16) & (0.35) \\ \text { Lnprice*agri } & -0.52 & -0.36 & -0.39 \\ & (0.37) & (0.25) & (0.48) \\ & & & \\ \text { Individual FE } & \text { Yes } & \text { Yes } & \text { Yes } \\ \text { Observations } & 2,394 & 2,394 & 2,394 \\ \text { R-squared } & 0.27 & 0.26 & 0.25 \\ \text { Adjusted R-squared } & 0.265 & 0.256 & 0.248\end{array}$

Wage effects implied by different elasticities

$\begin{array}{cccc}\Delta p & 157 \% & 214 \% & 68 \% \\ \epsilon_{w p} & 1.10 & 0.77 & 1.62 \\ \Delta p \times \epsilon_{w p} & 1.7 & 1.6 & 1.1\end{array}$

Note: In the upper panel, the dependent variable is the log of the real wage per hour in the last month. The independent variable Lnprice is the $\log$ of crop prices, whereby in column 1 the price equals the average yearly cotton FOB export price (of Tajikistan) for cotton PSUs and the average yearly wheat CIF import price (of Tajikistan) for non-cotton PSUs. Instead of average yearly prices, we use average sowing period prices (January until March) in column 2 and average harvest prices (two weeks before the respective interview) in column 3. In robustness checks not shown here, we also used the world market prices for cotton and wheat instead of FOB and CIF prices for Tajikistan and results do not change. All specifications are estimated for the sample of female workers using individual fixed effects estimation and include district dummies, province-year dummies, dummies for the month of the interview as well as dummies for cotton PSU, a dummy for working in agriculture (agri) and the interaction of cotton PSU and the agri dummy. The individual controls shown in Table 3, i.e., sex, age, dummies for the education and occupation of the individual as well as for working in a very large firm or in a state firm, are also included in all specifications, but are not shown in the table. The lower panel shows the results of a simple computation of the wage effects that are implied by the computed elasticities $\epsilon_{w p}$ in the upper panel. Note that $\Delta p$ is computed according to the official export price of Tajikistan. Robust standard errors (clustered at the PSU level) in parentheses *** $\mathrm{p}<0.01, * * \mathrm{p}<0.05,{ }^{*} \mathrm{p}<0.1$ Source: TLSS 2007-11. 
Table A18: FE estimation for Table 5

\begin{tabular}{|c|c|c|c|}
\hline \multirow[b]{4}{*}{ Dependent variable } & (1) & (2) & (3) \\
\hline & \multicolumn{3}{|c|}{ Children up to 17 years old } \\
\hline & Full Sample & Male & Female \\
\hline & \multicolumn{3}{|c|}{ Working in agriculture } \\
\hline \multirow[t]{2}{*}{ CottonPSU*year2009 } & 0.00 & -0.00 & 0.01 \\
\hline & $(0.01)$ & $(0.02)$ & $(0.01)$ \\
\hline \multirow[t]{2}{*}{ CottonPSU*year2011 } & $0.03 * *$ & 0.03 & $0.03 * * *$ \\
\hline & $(0.01)$ & $(0.02)$ & $(0.01)$ \\
\hline Individual FE & Yes & Yes & Yes \\
\hline Observations & 11,238 & 5,658 & 5,580 \\
\hline R-squared & 0.02 & 0.03 & 0.02 \\
\hline Adjusted R-squared & 0.0138 & 0.0218 & 0.0136 \\
\hline \multicolumn{4}{|c|}{$\begin{array}{l}\text { Note: The dependent variable is an indicator whether the child works in agriculture or not, whereby we use the sample of children up to age } \\
17 \text { (column } 1 \text { refers to the full sample, whereas column } 2 \text { and } 3 \text { show results for the male and female sub-samples, respectively). All } \\
\text { specifications are estimated using individual fixed effects estimation and include district dummies, province-year dummies, dummies for the } \\
\text { month of the interview as well as dummies for cotton PSU and the year of the interview. The individual controls shown in Table } 3 \text {, i.e., sex, } \\
\text { age, dummies for the education and occupation of the individual as well as for working in a very large firm or in a state firm, are also } \\
\text { included in all specifications, but are not shown in the table. As in Table } 2 \text { columns } 1-3 \text {, we include additional control variables at the } \\
\text { individual, PSU and sub-district level. Individual controls are available from the TLSS for each year of the sample and comprise dummies } \\
\text { for the ethnicity and the marital status of the individual as well as household size. PSU level controls are for the year } 2007 \text { and include the } \\
\text { distance of the PSU to the province capital, a dummy for urban location as well as measures for the importance of agriculture and male } \\
\text { unemployment in the PSU. Sub-district level control variables come from the World Bank Socio-Economic Atlas of Tajikistan (2005) and } \\
\text { refer either to the year } 2003 \text { or the year } 2000 \text {. They comprise the unemployment rate, the dependency ratio, the share of the economically } \\
\text { active (female) population, the share of households living below the poverty line, the log of the population density, the share of individuals } \\
\text { with primary education completed and the share with secondary education completed, the share of households with electrical power supply } \\
\text { in the dwelling as well as the share of households with a landline phone. For columns } 4-5 \text { of Table } 5 \text {, the estimation using individual fixed } \\
\text { effects was not possible due to the small amount of managers included in the TLSS survey. Robust standard errors (clustered at the PSU } \\
\text { level) in parentheses } * * * p<0.01, * * p<0.05, * \text { p }<0.1 \text { Source: TLSS } 2007-11 \text {. }\end{array}$} \\
\hline
\end{tabular}


Table A19: Controlling for the privatization process and monopsony power in Table 2

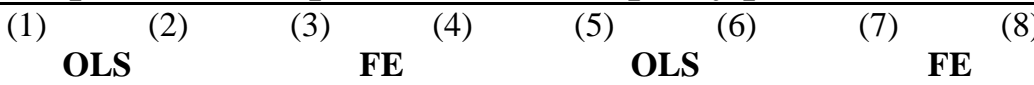

Dependent variable

Working in agriculture

Log of the real wage per hour

\begin{tabular}{|c|c|c|c|c|c|c|c|c|}
\hline CottonPSU*year2009 & $\begin{array}{c}0.03 \\
(0.06)\end{array}$ & $\begin{array}{c}0.04 \\
(0.06)\end{array}$ & $\begin{array}{c}0.02 \\
(0.07)\end{array}$ & $\begin{array}{c}0.02 \\
(0.06)\end{array}$ & $\begin{array}{l}0.35^{* *} \\
(0.16)\end{array}$ & $\begin{array}{c}0.19 \\
(0.15)\end{array}$ & $\begin{array}{c}0.16 \\
(0.18)\end{array}$ & $\begin{array}{c}0.06 \\
(0.18)\end{array}$ \\
\hline CottonPSU*year2011 & $\begin{array}{c}0.14 * * \\
(0.06)\end{array}$ & $\begin{array}{l}0.13 * * \\
(0.06)\end{array}$ & $\begin{array}{l}0.13 * * \\
(0.06)\end{array}$ & $\begin{array}{l}0.12 * \\
(0.06)\end{array}$ & $\begin{array}{l}-0.13 \\
(0.19)\end{array}$ & $\begin{array}{l}-0.19 \\
(0.17)\end{array}$ & $\begin{array}{l}-0.34 \\
(0.23)\end{array}$ & $\begin{array}{l}-0.34 * \\
(0.18)\end{array}$ \\
\hline CottonPSU*year $2009 *$ Agri & & & & & $\begin{array}{l}-0.45 \\
(0.33)\end{array}$ & $\begin{array}{l}-0.31 \\
(0.34)\end{array}$ & $\begin{array}{c}0.09 \\
(0.40)\end{array}$ & $\begin{array}{c}0.19 \\
(0.39)\end{array}$ \\
\hline CottonPSU*year2011*Agri & & & & & $\begin{array}{l}0.58 * * \\
(0.27)\end{array}$ & $\begin{array}{l}0.64 * * \\
(0.26)\end{array}$ & $\begin{array}{c}0.97 * * * \\
(0.31)\end{array}$ & $\begin{array}{r}0.98^{* * *} \\
(0.29)\end{array}$ \\
\hline $\begin{array}{l}\text { Share of small farm workers (per } \\
\text { distr.) }\end{array}$ & $\begin{array}{c}0.02 \\
(0.07)\end{array}$ & & $\begin{array}{c}0.03 \\
(0.08)\end{array}$ & & $\begin{array}{c}0.03 \\
(0.17)\end{array}$ & & $\begin{array}{c}0.30 \\
(0.20)\end{array}$ & \\
\hline $\begin{array}{l}\text { Nr. of new SCLG certificates } \\
\text { (sub-distr.) }\end{array}$ & & $\begin{array}{l}-0.03 \\
(0.04)\end{array}$ & & $\begin{array}{c}0.01 \\
(0.05)\end{array}$ & & $\begin{array}{c}0.14 \\
(0.15)\end{array}$ & & $\begin{array}{c}0.18 \\
(0.22)\end{array}$ \\
\hline Idivi & No & $\mathrm{N}$ & $\mathrm{Y}$ & $\mathrm{Yc}$ & $\mathrm{N}$ & $\mathrm{N}$ & $\mathrm{Y}$ & Yes \\
\hline Obser & 7,307 & 8,591 & 7,307 & 8,591 & 2,051 & 2,394 & 2,051 & 2,394 \\
\hline R-squ & 0.19 & 0.2 & 0. & 0.02 & & 0.41 & 0.31 & 0.32 \\
\hline Adjusted R-squared & 0.177 & 0.208 & 0.0170 & 0.0177 & 0.400 & 0.391 & 0.299 & 0.310 \\
\hline
\end{tabular}

Note: In columns 1-4, the dependent variable is an indicator whether the person works in agriculture or not, whereby we use the sample of the female working age population. In columns 5-8, the dependent variable is the log of the real wage per hour in the last month and the specifications are estimated for all female workers. The specifications in columns 1,2,5 and 6 are estimated using OLS and the specifications in columns 3, 4, 7 and 8 are estimated using individual fixed effects. In contrast to Table 3 and A16, we include two additional control variables. Columns 1, 3, 5 and 7 include the share of agricultural workers working on small farms (at most 25 employees) per district. Columns 2, 4, 6 and 8 include the number of newly issued SLCG land certificates for private farms at the sub-district level. All specifications include district dummies, province-year dummies, dummies for the month of the interview as well as dummies for cotton PSU and the year of the interview. Columns 5-8 additionally include a dummy for working in agriculture (agri) and its interactions with cotton PSU and the year dummies. As in Table 3, Columns 1-4 include additional control variables at the individual, PSU and sub-district level. Individual controls are available from the TLSS for each year of the sample and comprise dummies for the ethnicity and the marital status of the individual as well as household size. PSU level controls are for the year 2007 and include the distance of the PSU to the province capital, a dummy for urban location as well as measures for the importance of agriculture and male unemployment in the PSU. Sub-district level control variables come from the World Bank Socio-Economic Atlas of Tajikistan (2005) and refer either to the year 2003 or the year 2000. They comprise the unemployment rate, the dependency ratio, the share of the economically active (female) population, the share of households living below the poverty line, the log of the population density, the share of individuals with primary education completed and the share with secondary education completed, the share of households with electrical power supply in the dwelling as well as the share of households with a landline phone. The individual controls shown in Table 3, i.e., sex, age, dummies for the education and occupation of the individual as well as for working in a very large firm or in a state firm, are also included in all specifications, but are not shown in the table. Robust standard errors (clustered at the PSU level) in parentheses *** $\mathrm{p}<0.01, * * \mathrm{p}<0.05, * \mathrm{p}<0.1$ Source: TLSS 2007-11. 
Table A20: Controlling for the privatization process and monopsony power in Table 3
(1)
(2)
(3)
(4)
(5)
(6)
(7)

(8)

Large firms (>25 employees)

Small firms ( $\leq 25$ employees)

OLS

FE

OLS

FE

Dependent variable

CottonPSU*year2009*Agri

CottonPSU*year2011*Agri

Share of small farm workers (per

distr.)

Nr. of new SCLG certificates

(sub-distr.)

Individual FE

Observations

R-squared

Adjusted R-squared

Log of the real wage per hour

Note: The dependent variable is the log of the real wage per hour in the last month and the specifications are estimated for all female workers. Columns 1-4 only include women that work in firms with more than 25 employees, whereas columns 5-8 show results for women that work in firms with at most 25 employees. The specifications in columns 1, 2, 5 and 6 are estimated using OLS and the specifications in columns 3, 4, 7 and 8 are estimated using individual fixed effects. In contrast to Table 4 and A17, we include two additional control variables. Columns 1, 3, 5 and 7 include the share of agricultural workers working on small farms (at most 25 employees) per district. Columns 2, 4, 6 and 8 include the number of newly issued SLCG land certificates for private farms at the sub-district level. All specifications include district dummies, province-year dummies, dummies for the month of the interview as well as dummies for cotton PSU, the year of the interview and a dummy for working in agriculture (agri) as well as all interactions of cotton PSU, the year dummies and the agri dummy. The individual controls shown in Table 3, i.e., sex, age, dummies for the education and occupation of the individual as well as for working in a very large firm or in a state firm, are also included in all specifications, but are not shown in the table. Robust standard errors (clustered at the PSU level) in parentheses $* * * \mathrm{p}<0.01, * * \mathrm{p}<0.05, * \mathrm{p}<0.1$ Source: TLSS 2007-11. 
Table A21: Additional controls for the wage regressions in Tables 2 and 3

(1)

All workers
(2)

Large firms

$(>25$

employees)
(3)

Small firms

$(\leq 25$

employees)
Dependent variable

CottonPSU*year2009*Agri

CottonPSU*year2011*Agri

Pop. econ. active (sub-distr.)

Fem. pop. econ. active (sub-distr.)

Unemployment rate (sub-distr.)

Observations

R-squared

Adjusted R-squared Log of the real wage per hour more than 25 employees, whereas column 3 shows results for women that work in firms with at most 25 employees. All specifications include district dummies, province-year dummies, dummies for the month of the interview as well as dummies for cotton PSU, the year of the interview and a dummy for working in agriculture (agri) as well as all interactions of cotton PSU, the year dummies and the agri dummy. As in Table 3 columns 1-3, all specifications include additional control variables at the individual, PSU and sub-district level. Individual controls are available from the TLSS for each year of the sample and comprise dummies for the ethnicity and the marital status of the individual as well as household size. PSU level controls are for the year 2007 and include the distance of the PSU to the province capital, a dummy for urban location as well as measures for the importance of agriculture and male unemployment in the PSU. Sub-district level control variables come from the World Bank Socio-Economic Atlas of Tajikistan (2005) and refer either to the year 2003 or the year 2000. They comprise the unemployment rate, the dependency ratio, the share of the economically active (female) population, the share of households living below the poverty line, the log of the population density, the share of individuals with primary education completed and the share with secondary education completed, the share of households with electrical power supply in the dwelling as well as the share of households with a landline phone. The individual controls shown in Table 3, i.e., sex, age, dummies for the education and occupation of the individual as well as for working in a very large firm or in a state firm, are also included in all specifications, but are not shown in the table. Robust standard errors (clustered at the PSU level) in parentheses *** $\mathrm{p}<0.01, * * \mathrm{p}<0.05, * \mathrm{p}<0.1$ Source: TLSS 2007-11. 
Table A22: Continuous treatment at the district level

\begin{tabular}{ccccccc}
\hline & $(1)$ & $(2)$ & $(3)$ & $(4)$ & $(5)$ & $(6)$ \\
Full & Male & Female & Full & Male & Female \\
sample & & & sample & & &
\end{tabular}

Cotton production

Area harvested with cotton

Dependent variable

Cotton prod.*Share of small farm

workers (per distr.)

Cotton production (per distr.)

Share of small farm workers (per distr.)

Cotton area*Share of small farm

workers (per distr.)

Cotton area harvested (per distr.)

\section{Observations}

R-squared

Adjusted R-squared
Log of the real wage per hour

$\begin{array}{ccc}0.01 & -0.03 & 0.06^{*} \\ (0.03) & (0.03) & (0.03) \\ -0.02 & -0.03 & -0.01 \\ (0.02) & (0.03) & (0.03)\end{array}$

$\begin{array}{lll}-0.10 & 0.52 & -1.05 * *\end{array}$

$-0.33$

0.27

$-1.17 * *$

$(0.38)$

$(0.40)$

$(0.51)$

$(0.43)$

$(0.49)$

$(0.58)$

$0.04-0.03-0.12 *$

$\begin{array}{lll}(0.05) & (0.07) \quad(0.06)\end{array}$

$-0.10 * \quad-0.09 \quad-0.10$

$(0.05) \quad(0.06) \quad(0.06)$

Note: The dependent variable is the $\log$ of the real wage per hour in the last month. All specifications are estimated for the sample of all workers (column 1 and 4 refer to the full sample, column 2 and 5 show results for the male sub-sample and columns 3 and 6 for the female sub-sample). In columns 1-3, the continuous treatment is defined as the cotton production (in tons) per district. In columns 4-6, we use the area harvested with cotton (in hectares) per district as the continuous treatment variable. For both treatment definitions, we also include the share of agricultural workers working on small farms (at most 25 employees) per district and interact this variable with the respective continuous treatment variable. All specifications are estimated using OLS and include district dummies, province-year dummies, dummies for the month of the interview as well as dummies for cotton PSU and the year of the interview. The individual controls shown in Table 3 , i.e., sex, age, dummies for the education and occupation of the individual as well as for working in a very large firm or in a state firm, are also included in all specifications, but are not shown in the table. Robust standard errors (clustered at the PSU level) in parentheses $* * *$ $\mathrm{p}<0.01, * * \mathrm{p}<0.05, * \mathrm{p}<0.1$ Source: TLSS 2007-11. 
Table A23: District treatment

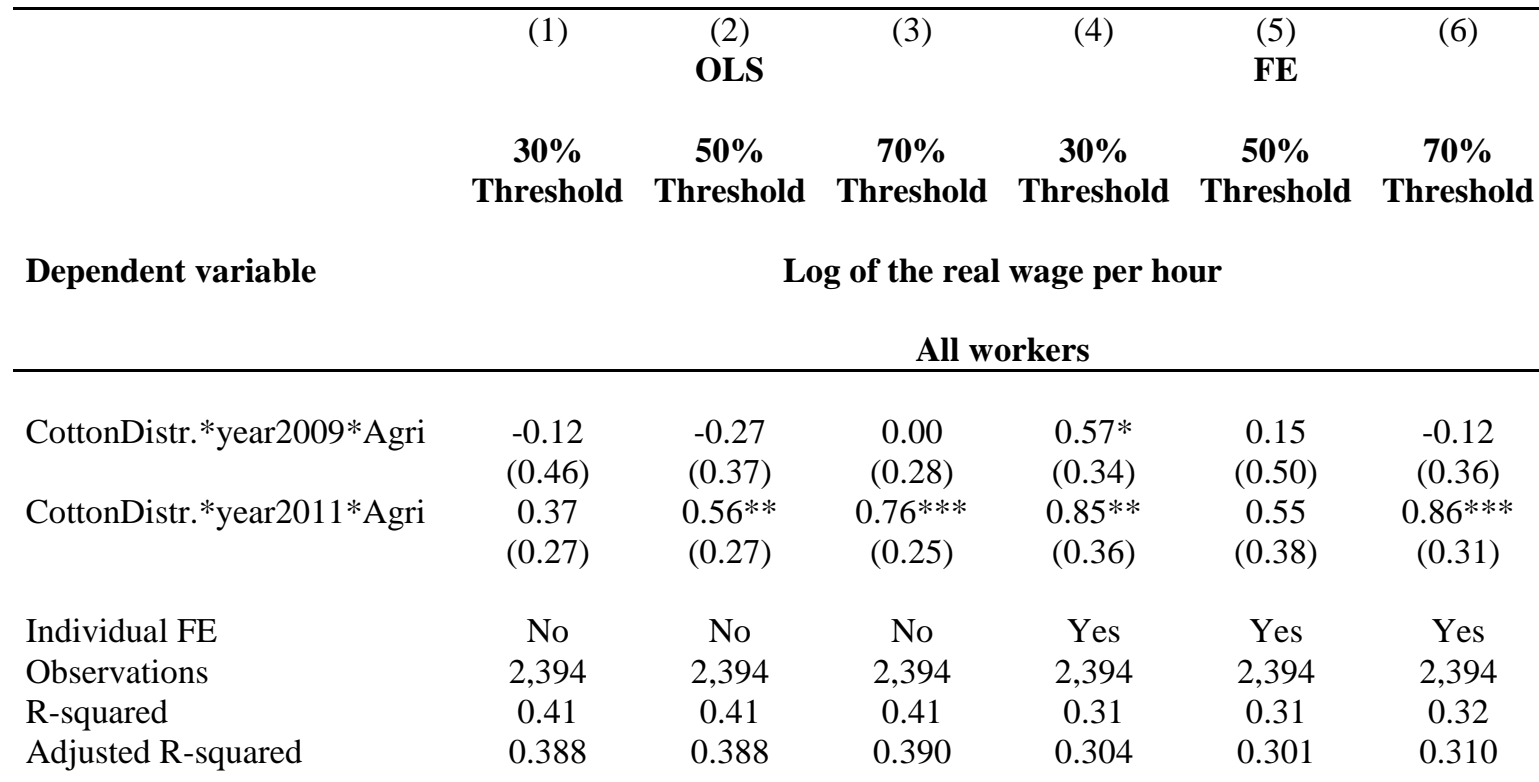

Large firms (>25 employees)

$\begin{array}{lcccccc}\text { CottonDistr. *year2009*Agri } & -0.63 * & -0.42 & 0.10 & 0.47 & 0.30 & 0.21 \\ & (0.37) & (0.30) & (0.25) & (0.33) & (0.33) & (0.30) \\ \text { CottonDistr. *year2011*Agri } & -0.59 * * & 0.21 & 0.19 & 0.47 & -0.50 & -0.55 \\ & (0.29) & (0.32) & (0.31) & (0.31) & (0.49) & (0.50) \\ & & & & & & \text { Yes } \\ \text { Individual FE } & \text { No } & \text { No } & \text { No } & \text { Yes } & \text { Yes } & 1,278 \\ \text { Observations } & 1,278 & 1,278 & 1,278 & 1,278 & 1,278 & 0.39 \\ \text { R-squared } & 0.51 & 0.50 & 0.50 & 0.39 & 0.39 & 0.377 \\ \text { Adjusted R-squared } & 0.472 & 0.471 & 0.470 & 0.377 & 0.376 & \end{array}$

Small firms $(\leq 25$ employees $)$

\begin{tabular}{lcccccc}
\hline & & & & & & \\
CottonDistr.*year2009*Agri & 0.19 & -0.01 & -0.11 & 0.88 & -0.63 & -0.19 \\
& $(0.44)$ & $(0.39)$ & $(0.37)$ & $(0.99)$ & $(1.20)$ & $(0.80)$ \\
CottonDistr.*year2011*Agri & $0.85^{* *}$ & $1.28^{* * *}$ & $1.26 * *$ & $1.86 * *$ & 1.04 & $1.40^{* *}$ \\
& $(0.37)$ & $(0.38)$ & $(0.38)$ & $(0.87)$ & $(0.86)$ & $(0.65)$ \\
& & & & & & Yes \\
Individual FE & No & No & No & Yes & Yes & 1,116 \\
Observations & 1,116 & 1,116 & 1,116 & 1,116 & 1,116 & 0.34 \\
R-squared & 0.38 & 0.39 & 0.39 & 0.33 & 0.33 & 0.322 \\
Adjusted R-squared & 0.334 & 0.336 & 0.339 & 0.316 & 0.313 &
\end{tabular}

Note: The dependent variable is the log of the real wage per hour in the last month. All specifications are estimated for the sub-sample of female workers. In the upper panel, we show results for the full sample of female workers. In the mid panel, we only include women that work in firms with more than 25 employees, and in the lower panel we only include women that work in firms with at most 25 employees. The specifications in columns 1-3 are estimated using OLS and the specifications in columns 4-6 are estimated using individual fixed effects. The treatment is defined at the district level (all PSUs in a cotton district are defined as cotton PSUs), whereby a district is defined as a cotton district, if at least 30\% (columns 1 and 4), at least 50\% (columns 2 and 5) or at least 70\% (columns 3 and 6) of the PSUs in the district are cotton growing PSUs. All specifications include district dummies, province-year dummies, dummies for the month of the interview as well as dummies for cotton district, the year of the interview and a dummy for working in agriculture (agri) as well as all interactions of cotton district, the year dummies and the agri dummy. The individual controls shown in Table 3, i.e., sex, age, dummies for the education and occupation of the individual as well as for working in a very large firm or in a state firm, are also included in all specifications, but are not shown in the table. Robust standard errors (clustered at the PSU level) in parentheses *** $\mathrm{p}<0.01, * * \mathrm{p}<0.05, * \mathrm{p}<0.1$ Source: TLSS 200711. 
Table A24: Other treatment definitions at the PSU level

\begin{tabular}{ccccccc}
\hline & $(1)$ & $(2)$ & $(3)$ & $(4)$ & $(5)$ & $(6)$ \\
& OLS & & & FE & \\
Lowland & FAO & FAO & Lowland & FAO & FAO \\
Definition & $\begin{array}{c}\text { Prod. } \\
\text { Capacity } \\
\text { Index 1 }\end{array}$ & $\begin{array}{c}\text { Prod. } \\
\text { Capacity } \\
\text { Index 2 }\end{array}$ & $\begin{array}{c}\text { Definition } \\
\text { Prod. } \\
\text { Papacity }\end{array}$ & $\begin{array}{c}\text { Papacity } \\
\text { Candex }\end{array}$ \\
& & & Index 1 & Index 2
\end{tabular}

Dependent variable
Log of the real wage per hour

All workers

$\begin{array}{lcccccc}\text { CottonPSU*year2009*Agri } & -0.03 & 0.01 & 0.11 & -0.27 & -0.56 & -0.70^{* *} \\ & (0.34) & (0.45) & (0.59) & (0.31) & (0.41) & (0.34) \\ \text { CottonPSU*year2011*Agri } & 1.00^{* * *} & 0.83^{* *} & 1.05^{* *} & 0.93 * * * & 0.58 & 0.39 \\ & (0.26) & (0.35) & (0.42) & (0.34) & (0.38) & (0.37) \\ & & & & & & \\ \text { Individual FE } & \text { No } & \text { No } & \text { No } & \text { Yes } & \text { Yes } & \text { Yes } \\ \text { Observations } & 2,394 & 2,394 & 2,394 & 2,394 & 2,394 & 2,394 \\ \text { R-squared } & 0.41 & 0.41 & 0.41 & 0.31 & 0.31 & 0.31 \\ \text { Adjusted R-squared } & 0.391 & 0.390 & 0.389 & 0.303 & 0.304 & 0.298\end{array}$

Large firms (>25 employees)

$\begin{array}{lcccccc}\text { CottonPSU*year2009*Agri } & -0.21 & -0.73 * & -0.67 & 0.68 & -0.46 & -0.03 \\ & (0.45) & (0.38) & (0.68) & (0.41) & (0.64) & (0.38) \\ \text { CottonPSU*year2011*Agri } & -0.55 & 0.22 & 0.22 & 0.34 & 0.27 & 0.29 \\ & (0.42) & (0.19) & (0.19) & (0.30) & (0.30) & (0.30) \\ & & & & & & \\ \text { Individual FE } & \text { No } & \text { No } & \text { No } & \text { Yes } & \text { Yes } & \text { Yes } \\ \text { Observations } & 1,278 & 1,278 & 1,278 & 1,278 & 1,278 & 1,278 \\ \text { R-squared } & 0.50 & 0.51 & 0.51 & 0.39 & 0.40 & 0.39 \\ \text { Adjusted R-squared } & 0.469 & 0.473 & 0.472 & 0.375 & 0.384 & 0.375\end{array}$

Small firms ( $\leq 25$ employees)

\begin{tabular}{lcccccc} 
CottonPSU*year2009*Agri & -0.50 & -0.16 & $-0.89^{* *}$ & $-1.41^{* *}$ & -1.14 & $-1.56^{* *}$ \\
& $(0.46)$ & $(0.53)$ & $(0.43)$ & $(0.58)$ & $(0.76)$ & $(0.68)$ \\
CottonPSU*year2011*Agri & $1.10^{* * *}$ & $0.85^{*}$ & $1.04 *$ & $0.97 *$ & $1.94 * *$ & $2.19^{* * *}$ \\
& $(0.40)$ & $(0.44)$ & $(0.53)$ & $(0.54)$ & $(0.88)$ & $(0.64)$ \\
& & & & & & \\
Individual FE & $\mathrm{No}$ & $\mathrm{No}$ & $\mathrm{No}$ & $\mathrm{Yes}$ & Yes & Yes \\
Observations & 1,116 & 1,116 & 1,116 & 1,116 & 1,116 & 1,116 \\
R-squared & 0.39 & 0.39 & 0.38 & 0.34 & 0.32 & 0.32 \\
Adjusted R-squared & 0.336 & 0.337 & 0.331 & 0.321 & 0.301 & 0.304 \\
\hline
\end{tabular}

Note: The dependent variable is the log of the real wage per hour in the last month. All specifications are estimated for the sub-sample of female workers. In the upper panel, we show results for the full sample of female workers. In the mid panel, we only include women that work in firms with more than 25 employees, and in the lower panel we only include women that work in firms with at most 25 employees. The specifications in columns 1-3 are estimated using OLS and the specifications in columns 4-6 are estimated using individual fixed effects. We use alternative definitions for a cotton growing PSU, whereby columns 1 and 4 use the low land definition (PSU lies below 1000m altitude) and columns 2 and 5 as well as 3 and 6 use the FAO cotton production capacity index 1 and 2, respectively (Appendix B). All specifications include district dummies, province-year dummies, dummies for the month of the interview as well as dummies for cotton PSU, the year of the interview and a dummy for working in agriculture (agri) as well as all interactions of cotton PSU, the year dummies and the agri dummy. The individual controls shown in Table 3, i.e., sex, age, dummies for the education and occupation of the individual as well as for working in a very large firm or in a state firm, are also included in all specifications, but are not shown in the table. Robust standard errors (clustered at the PSU level) in parentheses *** $\mathrm{p}<0.01$, ** $\mathrm{p}<0.05$, * $\mathrm{p}<0.1$ Source: TLSS 2007-11. 


\section{Appendix B - Description of Data Sources and Variables}

\section{Comparison of different treatment definitions}

\begin{tabular}{|c|c|c|c|}
\hline Treatment Definition & Data Source & $\begin{array}{l}\text { Level of Aggregation of } \\
\text { the treatment definition }\end{array}$ & Description \\
\hline Baseline & $\begin{array}{l}\text { TLSS } 2007 \text { community } \\
\text { questionnaire } \\
\text { (answered by mayor) }\end{array}$ & Community (PSU) level & $\begin{array}{l}\text { Cotton is the first or } \\
\text { second most important } \\
\text { crop in the community }\end{array}$ \\
\hline FAO PP1 & FAO GAEZ data base & Community (PSU) level & $\begin{array}{l}\text { Production Capacity } \\
\text { Index for intermediate } \\
\text { input level irrigated } \\
\text { cotton is }>0 \text { for the } \\
\text { community }\end{array}$ \\
\hline FAO PP2 & FAO GAEZ data base & Community (PSU) level & $\begin{array}{l}\text { Production Capacity } \\
\text { Index for low input level } \\
\text { irrigated cotton is }>0 \text { for } \\
\text { the community }\end{array}$ \\
\hline Lowland Definition & $\begin{array}{l}\text { TLSS } 2007 \text { community } \\
\text { questionnaire }\end{array}$ & Community (PSU) level & $\begin{array}{l}\text { Altitude of the } \\
\text { community is }<1000 \mathrm{~m}\end{array}$ \\
\hline District Baseline & $\begin{array}{l}\text { TLSS } 2007 \text { community } \\
\text { questionnaire }\end{array}$ & District level & $\begin{array}{l}\text { The district is treated, if } \\
\text { more than } 30 \%(50 \% \text {, } \\
70 \%) \text { of the communities } \\
\text { in the sample are treated } \\
\text { according to the baseline } \\
\text { treatment definition } 1\end{array}$ \\
\hline
\end{tabular}

List of variables

\section{Variable Name}

\section{Dependent Variables}

Log of the real wage per hour

Log of the real monthly wage

Working in Agriculture

\section{Variable Description}

Log of the real wage per hour in the last month

Log of the real wage in the last month

Indicator whether the person works in agriculture or not (out of the working age population)

\section{Independent Variables}

\section{CottonPSU}

Year2009

Year2011

District dummies

Province-year dummies

Month dummies

Small

Agri

Female

Age

Secondary educ.

Tertiary educ.
Indicator for a cotton growing community (PSU); five different treatment definitions (see the paper section 2 and Appendix B)

Indicator for the year 2009

Indicator for the year 2011

56 indicators for each of the 56 districts included in the TLSS panel survey

Five indicator variables for the five Oblasts (Provinces) of Tajikistan interacted with the indicators for the year 2009 and 2011

Indicators for the month of the interview (August until December)

Indicator for working in a small firm ( $\leq 25$ employees) Indicator whether the person works in agriculture Indicator for being female

Age of the individual

Indicator whether the individual has finished secondary education Indicator whether the individual has finished tertiary 
Large firm

State firm

Occ. high

Occ. middle

Occ. skilled agric.

Lnprice education

Indicator for working in a very large firm (>50 employees)

Indicator for working in a state owned firm

Indicator for working in occupation categories 1, 2 and 3

Indicator for working occupation categories 4,5,7 and 8

Indicator for working in skilled agricultural occupations (occupation code 6)

Log of crop prices, whereby the price equals the average yearly cotton FOB export price (of Tajikistan) for cotton PSUs and the average yearly wheat CIF import price (of Tajikistan) for non-cotton PSUs; we also use average sowing period (January until March) and average harvest prices (two weeks before the respective interview) as well as the world market prices for cotton and wheat instead of FOB and CIF prices for Tajikistan

\section{Additional Control Variables}

Share of small farm workers (per distr.)

Nr. of new SCLG certificates (sub-distr.)

\section{Cotton Area}

Cotton Production
District share of agricultural workers working on small farms out of all agricultural workers (computed from the TLSS for 2007, 2009 and 2011)

Number of newly issued land certificates for private farms at the sub-district level (issued by the Tajik State Committee for Land ad Geodesy)

Area harvested with cotton in hectare per district (TajStat and FAO Tajikistan)

Cotton production in tons per district (TajStat and FAO Tajikistan)

\section{PSU and Jamoat Control Variables}

Distance to province capital

Urban

Male unemployment in PSU

Employment share in agriculture in PSU

Poverty in the sub-district

Pop. econ. active (sub-distr.)

Fem. Pop. econ. active (sub-distr.)

Unemployment rate (sub-distr.)

Dependency ratio in the sub-district

Population density in the sub-district

Share of sub-district population with low education
Distance of the PSU to the capital of the province (oblast) (TLSS)

Indicator for urban location of the PSU (TLSS)

Ordinal measure of male unemployment in the PSU in 2007 (TLSS)

Ordinal measure of share of workforce engaged in agriculture in the PSU in 2007 (TLSS)

Share of households whose level of daily consumption is below the 40th percentile of consumption expenditure in the sub-district in 2003 (WB SocioEconomic Atlas of Tajikistan)

Share of the working age population that was economically active in the sub-district in 2000 (WB Socio-Economic Atlas of Tajikistan)

Share of the female working age population that was economically active in the sub-district in 2000 (WB Socio-Economic Atlas of Tajikistan)

Unemployment rate in the sub-district in 2000 (WB Socio-Economic Atlas of Tajikistan)

Ratio of the population aged under 15 or over 64 years to the population aged 15 to 64 per sub-district in 2000 (WB Socio-Economic Atlas of Tajikistan) Population Density in the sub-district in 2000 (WB Socio-Economic Atlas of Tajikistan)

Share of the sub-district population with primary or no education in 2000 (WB Socio-Economic Atlas of 
Tajikistan)

Share of sub-district population with secondary Share of the sub-district population with secondary education education in 2000 (WB Socio-Economic Atlas of Tajikistan)

Electricity infrastructure

Percentage of households with an electrical power supply in the dwelling in the sub-district in 2000 (WB Socio-Economic Atlas of Tajikistan)

Telephone infrastructure Percentage of households with a landline phone in the dwelling in the sub-district in 2000 (WB SocioEconomic Atlas of Tajikistan)

\section{Household and individual level control variables}

Ethnicity

Marital status

Household size
Indicators for the ethnicity of the individual (1 if Tajik and 0 otherwise; based on TLSS)

Indicators for marital status of the individual ( 1 if married and 0 otherwise; based on TLSS)

Number of household members (TLSS) 


\section{List of data sets used in the paper}

\begin{tabular}{|c|c|c|c|c|c|}
\hline \multicolumn{2}{|c|}{ Dataset } & Source & $\begin{array}{l}\text { Year the data was } \\
\text { collected }\end{array}$ & Respondents/Content & $\begin{array}{c}\text { Number of Individual } \\
\text { Observations }\end{array}$ \\
\hline \multicolumn{6}{|c|}{ Household Panel Survey } \\
\hline \multirow[t]{2}{*}{$\begin{array}{l}\text { Tajikistan } \\
\text { Standards } \\
\text { Measurement } \\
\text { (TLSS) } 2007\end{array}$} & $\begin{array}{l}\text { Living } \\
\text { Survey }\end{array}$ & $\begin{array}{l}\text { The World Bank website } \\
\text { (publicly available) }\end{array}$ & 2007 (harvest season) & $\begin{array}{l}\text { Representative Sample of } \\
4860 \text { Tajik Households } \\
\text { in } 270 \text { Primary Sampling } \\
\text { Units (PSU); }\end{array}$ & 30318 individuals \\
\hline & & & & $\begin{array}{l}\text { Additional detailed PSU } \\
\text { level information on } \\
\text { socio-economic, } \\
\text { demographic, geographic } \\
\text { and agricultural } \\
\text { characteristics }\end{array}$ & \\
\hline $\begin{array}{l}\text { Tajikistan } \\
\text { Standards } \\
\text { Measurement } \\
\text { (TLSS) } 2009\end{array}$ & $\begin{array}{l}\text { Living } \\
\text { Survey }\end{array}$ & $\begin{array}{l}\text { The World Bank website } \\
\text { (publicly available) }\end{array}$ & 2009 (harvest season) & $\begin{array}{l}1503 \text { Households out of } \\
\text { the } 4860 \text { Households } \\
\text { from TLSS } 2007 \text { (Panel } \\
\text { data), } 167 \text { PSUs }\end{array}$ & 10069 individuals \\
\hline $\begin{array}{l}\text { Tajikistan } \\
\text { Standards } \\
\text { Measurement } \\
\text { (TLSS) 2011 }\end{array}$ & $\begin{array}{l}\text { Living } \\
\text { Survey }\end{array}$ & $\begin{array}{l}\text { The Institute for East and } \\
\text { Southeast European } \\
\text { Studies (IOS) in } \\
\text { Regensburg, Germany }\end{array}$ & 2011 (harvest season) & $\begin{array}{l}1503 \text { Households from } \\
\text { TLSS 2007 and } 2009 \\
\text { (Panel data), } 167 \text { PSUs }\end{array}$ & 9608 individuals \\
\hline
\end{tabular}

Detailed statistical information on Tajikistan matched with the TLSS panel data

\begin{tabular}{llll}
\hline $\begin{array}{l}\text { Global Agro-Ecological } \\
\text { Database }\end{array}$ & $\begin{array}{l}\text { FAO - GAEZ website } \\
\text { (publicly available) }\end{array}$ & 1961-1990 & $\begin{array}{l}\text { Production suitability } \\
\text { indices for cotton for the } \\
\text { (GAEZ) from the Food }\end{array}$ \\
and Agricultural & & & $\begin{array}{l}\text { territory of Tajikistan } \\
\text { (GIS data) }\end{array}$ \\
Organization (FAO) & &
\end{tabular}

Socio-Economic Atlas of Tajikistan 2005
Number of land use certificates for small farms $(\leq 25$ employees $)$ by sub-district

\section{Cotton Sector Statistic for Tajikistan}

AO Crop Statistics for Tajikistan

Price Statistics for Tajikistan
The World Bank and GeoData Institute at the University Southampton;

Data obtained from Cem Mete (World Bank) Craig Hutton and Andy Murdoch (GeoData Institute)

Land use certificates handed out by the Tajik State Committee for Land and Geodesy (SCLG);

Data obtained during an interview with staff of World Bank Tajikistan in November 2014

National Statistics Institute of Tajikistan (TajStat), Year Book for the Cotton Sector (purchased in Dushanbe in March 2014)

FAO

Office

Tajikistan; Data obtained during an interview with a staff member in November 2014

National Statistics Agency of Tajikistan (website)
2000 (poverty variables are for the year 2003)

January 2007 until July 2011 (project ended in July 2011)

2007-2011

2000-2012

2000-2012
Socio-economic variables at the subdistrict (Jamoat) level for Tajikistan for the year 2000;

GIS information on borders of districts and oblasts of Tajikistan

Number of land use certificates for small farms ( $\leq 25$ employees) handed out by the SCLG at the sub-district level (Jamoat)

Cotton sector statistics by district (hukumat); Cotton production and area planted with cotton by district

Statistics on production, area harvested and yields for various crops by district (hukumat)

FOB cotton export prices, CIF wheat import price and consumer price index (CPI) for
Data matched with all 270 PSUs in the TLSS through GIS GEOcoordinates of the PSUs (which were retrieved from various sources, see Appendix)

Jamoat data matched with all 270 PSUs in the TLSS at the sub-district level (Jamoats) by hand; GIS information on district borders matched with PSU coordinates using Quantum GIS

Data matched with all 270 PSUs in the TLSS at the sub-district level (Jamoats) by hand

Data matched with al 270 PSUs in the TLSS at the district level by hand

Data matched with all 270 PSUs in the TLSS at the district level by hand

CPI matched by year; FOB export price for cotton matched to PSUs in cotton regions, CIF import price for wheat 
IMF Commodity Price International Monetary 2000-2012

Index
Cotton and wheat world market price indices
World market price for cotton matched to PSUs in cotton regions, CIF world market price for wheat matched to PSUs in non-cotton regions

Micro datasets collected in Tajikistan in March and November 2014

\begin{tabular}{|c|c|c|c|c|}
\hline $\begin{array}{l}\text { GIZ - Political Leader } \\
\text { Survey } 2011\end{array}$ & $\begin{array}{lr}\text { German } & \text { Federal } \\
\text { Enterprise rer } & \text { for } \\
\text { International Cooperation } \\
\text { (GIZ), Office Tajikistan }\end{array}$ & End of 2011 & $\begin{array}{l}\text { District and Jamoat } \\
\text { Leaders from all 58 } \\
\text { districts of Tajikistan; } \\
\text { Questions about the } \\
\text { agricultural reform } \\
\text { process in Tajikistan }\end{array}$ & $\begin{array}{l}672 \text { heads of districts and } \\
\text { sub-districts }\end{array}$ \\
\hline $\begin{array}{l}\text { GIZ Farm Head Survey } \\
2011\end{array}$ & $\begin{array}{l}\text { GIZ Office Tajikistan; } \\
\text { Survey conducted by } \\
\text { Mattes Scheftelowitz }\end{array}$ & $\begin{array}{l}\text { November } 2011 \text { until } \\
\text { March } 2012\end{array}$ & $\begin{array}{l}\text { Heads of small private } \\
\text { dehkan and large } \\
\text { collective farms from } 13 \\
\text { cotton growing districts } \\
\text { in Tajikistan }\end{array}$ & 253 farm heads \\
\hline GIZ Farm Survey 2013 & GIZ Office Tajikistan & End of 2013 & $\begin{array}{l}\text { Heads of all types of } \\
\text { farms from } 51 \text { districts in } \\
\text { Tajikistan; Information } \\
\text { on farm characteristics }\end{array}$ & 4253 farms \\
\hline FAO Farm Survey 2005 & $\begin{array}{l}\text { FAO Publication } \\
\text { Caccavale (2005) }\end{array}$ & 2005 & $\begin{array}{l}\text { Small holder dehkan } \\
\text { farmers and heads of } \\
\text { collective farms from all } \\
\text { districts of Tajikistan }\end{array}$ & 135 farms \\
\hline
\end{tabular}

Statistical data on Tajikistan used for descriptive statistics

\begin{tabular}{|c|c|c|c|}
\hline $\begin{array}{l}\text { Statistical Year Books } \\
\text { for Agriculture in } \\
\text { Tajikistan }\end{array}$ & 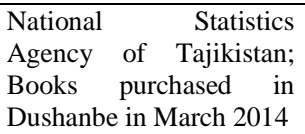 & $\begin{array}{l}1995-2013 \\
\text { (some data only available } \\
\text { from } 2006 \text { on) }\end{array}$ & $\begin{array}{l}\text { Agricultural statistics by } \\
\text { district }\end{array}$ \\
\hline $\begin{array}{l}\text { District level data on } \\
\text { cotton production by } \\
\text { farm size }\end{array}$ & $\begin{array}{l}\text { National Statistics } \\
\text { Agency of Tajikistan; } \\
\text { Data obtained during an } \\
\text { interview with a staff } \\
\text { member in November } \\
2014\end{array}$ & $2007-2011$ & $\begin{array}{l}\text { Cotton production and } \\
\text { area harvested with } \\
\text { cotton for small vs. large } \\
\text { farms ( } 20 \text { ha as } \\
\text { threshold) for all districts } \\
\text { in the provinces Sughd } \\
\text { and RRP as well as for } \\
\text { Khatlon province and the } \\
\text { Republic of Tajikistan }\end{array}$ \\
\hline $\begin{array}{l}\text { FAO data on the } \\
\text { privatization process }\end{array}$ & $\begin{array}{l}\text { FAO Mission Reports for } \\
\text { Tajikistan } 2009 \text { and } 2011\end{array}$ & 2006,2010 & $\begin{array}{l}\text { Number and area } \\
\text { cultivated by private } \\
\text { dehkan vs. collective } \\
\text { farms }\end{array}$ \\
\hline $\begin{array}{ll}\text { FAO } & \text { Agricultural } \\
\text { Statistics } & \end{array}$ & $\begin{array}{l}\text { FAO website (publicly } \\
\text { available) }\end{array}$ & 2000-2012 & $\begin{array}{l}\text { Production statistics for } \\
\text { Tajikistan for various } \\
\text { crops }\end{array}$ \\
\hline $\begin{array}{lr}\text { USDA } & \text { Foreign } \\
\text { Agricultural } & \text { Service } \\
\text { (FAS) Database } & \end{array}$ & $\begin{array}{l}\text { US Department of } \\
\text { Agriculture } \\
\text { website } \\
\text { available) }\end{array}$ & 2000-2012 & $\begin{array}{l}\text { Production, harvested } \\
\text { area, exports and imports } \\
\text { for various crops and all } \\
\text { countries }\end{array}$ \\
\hline
\end{tabular}




\section{Appendix C: Theoretical Model}

Based on the insights from the background section, we present a simple model that captures the main features of the Tajik cotton sector and describes the pass-through of the world cotton price surge to wages of cotton pickers.

We assume that there is a representative farm that describes the basic decision problem on small private dehkan farms as well as on larger collective farms in cotton growing areas of Tajikistan. Both farm types only differ in the characteristics of their labor supply curves. Both use the same constant returns to scale Cobb-Douglas production technology to produce cotton or wheat. ${ }^{37}$ The total land endowment per farm is fixed $(\bar{Z})$, because land markets do not exist in Tajikistan and farmers cannot increase land endowments in the short and medium run. Thus, the fixed amount of land $\bar{Z}$ is allocated between cotton and wheat production (a common assumption in agricultural economics, see Shumway et al. 1984). ${ }^{38}$ The second production factor is labor (L), whereby cotton is more labor intensive than wheat, especially during harvest time. ${ }^{39}$

\section{1.) Model for the representative farm}

\section{Cotton production $(\mathbf{X})$}

$$
X=Z_{x}^{1-\alpha} L_{x}^{\alpha}
$$

\section{Wheat production (Y)}

$$
Y=Z_{y}^{1-\beta} L_{y}^{\beta}
$$

$\alpha>\beta$ Cotton is more labor intensive than wheat (for all relative factor prices)

Profit Maximization of the representative farm (decision variables are $Z_{x}, Z_{y}, L_{x}, L_{y}$ ):

$$
\pi_{f}=p_{x} X+p_{y} Y-(1+r) w\left(L_{x}+L_{y}\right)
$$

s. t. production functions for $\mathrm{X}$ and $\mathrm{Y}$ and the resource constraint $\bar{Z} \geq Z_{x}+Z_{y}$

$\mathrm{p}_{\mathrm{x}}$ is the farm gate price for raw cotton, $\mathrm{p}_{\mathrm{y}}$ is the farm gate price for wheat, $\mathrm{r}$ is the interest rate and $\mathrm{w}$ is the wage for agricultural labor that is mobile between cotton and wheat production. The farm manager has to pre-finance input costs through loans with interest rate $r$. The representative farm is a price taker on product and factor markets. We follow Shumway et al. (1984) and do not include costs for the fixed but allocatable input land (because it is fixed in the short and medium run at the farm level).

\section{Solutions to the constraint maximization problem:}

\footnotetext{
${ }^{37}$ For farms in Tajikistan that produce cotton, wheat is the main crop alternative (FAO 2009, 2011). Wheat can also be grown outside of cotton growing areas (without irrigation infrastructure).

${ }^{38}$ From the interviews and GIZ farm head survey (table), we know that farm heads of small and large farms in Tajikistan follow world prices of cotton and use this information for their production decisions. They can freely allocate land between production of cotton and production of wheat as long as a minimum amount of land is placed under cotton (around 40-50\%, cotton quotas vary between districts). The fact that wheat area and supply increased dramatically in 2009 (in exchange for cotton) as a reaction to the high wheat prices in 2008/2009 further supports the hypothesis that farms can freely reallocate land between crops (FAO 2009). For simplicity reasons, we will not include a minimum share of land to be cropped with cotton in the model. However, it is straightforward to include this cotton quota in the model.

${ }^{39}$ For simplicity reasons, other inputs (N) (like fertilizer, insecticides, fuel and machinery) are left out in this version of the model. They can easily be included in the equations.
} 
Defining:

$$
A=\frac{(1-\alpha) p_{x}^{\frac{1}{1-\alpha}} \alpha^{\frac{\alpha}{1-\alpha}}}{(1-\beta) p_{y}^{\frac{1}{1-\beta}} \beta^{\frac{\beta}{1-\beta}}}(w(1+r))^{\frac{\beta}{1-\beta}-\frac{\alpha}{1-\alpha}}
$$

$Z_{x}^{*}\left(p_{x}, p_{y}, w, r, \bar{Z}\right)=\frac{A \bar{Z}}{1+A}$

Demand for land in cotton production

$Z_{y}^{*}\left(p_{x}, p_{y}, w, r, \bar{Z}\right)=\frac{\bar{Z}}{1+A}$

Demand for land in wheat production

$L_{x}^{*}\left(p_{x}, p_{y}, w, r, \bar{Z}\right)=\left(\frac{p_{x} \alpha}{(1+r) w}\right)^{\frac{1}{1-\alpha}} \frac{A \bar{Z}}{1+A}$

Demand for labor in cotton production

$L_{y}^{*}\left(p_{x}, p_{y}, w, r, \bar{Z}\right)=\left(\frac{p_{y} \beta}{(1+r) w}\right)^{\frac{1}{1-\beta}} \frac{\bar{Z}}{1+A}$

Demand for labor in wheat production

$X^{*}\left(p_{x}, p_{y}, w, r, \bar{Z}\right)=\left(\frac{p_{x} \alpha}{(1+r) w}\right)^{\frac{\alpha}{1-\alpha}} \frac{A \bar{Z}}{1+A}$

Optimal output in cotton production

$Y^{*}\left(p_{x}, p_{y}, w, r, \bar{Z}\right)=\left(\frac{p_{y} \beta}{(1+r) w}\right)^{\frac{\beta}{1-\beta}} \frac{\bar{Z}}{1+A}$

Optimal output in wheat production

\section{Comparative statistics:}

\section{1.) Reaction of the labor demand of the farm to an increase in $p_{x}$ :}

It is straightforward to show that:

$$
\begin{gathered}
\frac{d L_{x}^{*}\left(p_{x}, p_{y}, w, r, \bar{Z}\right)}{d p_{x}}=\frac{A \bar{Z}}{1+A}\left(\frac{p_{x} \alpha}{(1+r) w}\right)^{\frac{1}{1-\alpha}} \frac{1}{(1-\alpha) p_{x}}\left(\frac{2+A}{1+A}\right)>0 \\
\frac{d L_{y}^{*}\left(p_{x}, p_{y}, w, r, \bar{Z}\right)}{d p_{x}}=-\frac{A \bar{Z}}{1+A}\left(\frac{p_{y} \beta}{(1+r) w}\right)^{\frac{1}{1-\beta}} \frac{1}{(1-\alpha) p_{x}}\left(\frac{1}{1+A}\right)<0
\end{gathered}
$$

And the change in total labor demand of the farm:

$$
\begin{aligned}
& \frac{d\left(L_{x}^{*}\left(p_{x}, p_{y}, w, r, \bar{Z}\right)+L_{y}^{*}\left(p_{x}, p_{y}, w, r, \bar{Z}\right)\right)}{d p_{x}} \\
& =\frac{A \bar{Z}}{(1+A)} \frac{1}{(1-\alpha) p_{x}}\left(\left(\frac{p_{x} \alpha}{(1+r) w}\right)^{\frac{1}{1-\alpha}}\left(\frac{2+A}{1+A}\right)-\left(\frac{p_{y} \beta}{(1+r) w}\right)^{\frac{1}{1-\beta}}\left(\frac{1}{1+A}\right)\right)
\end{aligned}
$$

If $\alpha>\beta$ (cotton is more labor intensive than wheat, this is the main assumption) and $\frac{p_{x}}{p_{y}}>\frac{\beta}{\alpha}$ total labor demand on the farm increases in $p_{x}$ at all values of the independent variables (for other cases it is not trivial to show that). This inequality should hold almost surely, because the price for a ton of cotton has been higher than for a ton of wheat over the last decades. 


\section{Elasticities of labor demand w.r.t. a change in $p_{x}$ :}

$$
\begin{gathered}
\varepsilon_{L_{x}^{*}\left(p_{x}, p_{y}, w, r, \bar{z}\right), p_{x}}=\frac{1}{(1-\alpha)}\left(1+\frac{1}{1+A}\right)>0 \\
\varepsilon_{L_{Y}^{*}\left(p_{x}, p_{y}, w, r, \bar{Z}\right), p_{x}}=-\frac{1}{(1-\alpha)} \frac{A}{1+A}<0
\end{gathered}
$$

And the difference between the elasticities:

$$
\varepsilon_{L_{x}^{*}\left(p_{x}, p_{y}, w, r, \bar{Z}\right), p_{x}}-\varepsilon_{L_{Y}^{*}\left(p_{x}, p_{y}, w, r, \bar{Z}\right), p_{x}}=\frac{1}{(1-\alpha)}\left(\frac{2}{1+A}\right)>0
$$

Elasticity of the total labor demand of the farm:

$$
\varepsilon_{L_{\text {Total }}^{*}\left(p_{x}, p_{y}, w, r, \bar{z}\right), p_{x}}=\frac{\frac{A}{(1-\alpha)}\left(\left(\frac{p_{x} \alpha}{(1+r) w}\right)^{\frac{1}{1-\alpha}}\left(\frac{2+A}{1+A}\right)-\left(\frac{p_{y} \beta}{(1+r) w}\right)^{\frac{1}{1-\beta}}\left(\frac{1}{1+A}\right)\right)}{\left(\frac{p_{x} \alpha}{(1+r) w}\right)^{\frac{1}{1-\alpha}} A+\left(\frac{p_{y} \beta}{(1+r) w}\right)^{\frac{1}{1-\beta}}}
$$

The denominator is always positive. The numerator is positive if $\alpha>\beta$ and $\frac{p_{x}}{p_{y}}>\frac{\beta}{\alpha}$. Thus, in those cases the elasticity of total labor demand w.r.t. $p_{x}$ increases at all values of the independent variables.

\section{2.) Reaction of the labor demand of the farm to an increase in w:}

It is straightforward to show that for $\alpha>\beta$

$$
\frac{d L_{x}^{*}\left(p_{x}, p_{y}, w, r, \bar{Z}\right)}{d w}=\frac{A \bar{Z}}{(1+A) w}\left(\frac{p_{x} \alpha}{(1+r) w}\right)^{\frac{1}{1-\alpha}}\left(\frac{\frac{\beta}{1-\beta}-\frac{\alpha}{1-\alpha}}{1+A}-\frac{1}{(1-\alpha)}\right)<0
$$

And:

$$
\frac{d L_{y}^{*}\left(p_{x}, p_{y}, w, r, \bar{Z}\right)}{d w}=-\frac{\bar{Z}}{(1+A) w}\left(\frac{p_{y} \beta}{(1+r) w}\right)^{\frac{1}{1-\beta}}\left(\frac{1}{(1-\beta)}+\frac{A}{1+A}\left(\frac{\beta}{1-\beta}-\frac{\alpha}{1-\alpha}\right)\right)
$$

If $1<\alpha+(\alpha-\beta) \frac{A}{1+A}$ with $\frac{A}{1+A} \epsilon(0,1)$ then $\frac{d L_{y}^{*}\left(p_{x}, p_{y}, w, r, \bar{z}\right)}{d w}>0$

And the change in total labor demand of the farm: 


$$
\begin{aligned}
& \frac{d\left(L_{x}^{*}\left(p_{x}, p_{y}, w, r, \bar{Z}\right)+L_{y}^{*}\left(p_{x}, p_{y}, w, r, \bar{Z}\right)\right)}{d w} \\
& =\frac{A \bar{Z}}{(1+A) w}\left(\frac{\left.\frac{\beta}{1-\beta}-\frac{\alpha}{1-\alpha}\right)}{1+A}\right)\left(\left(\frac{p_{x} \alpha}{(1+r) w}\right)^{\frac{1}{1-\alpha}}-\left(\frac{p_{y} \beta}{(1+r) w}\right)^{\frac{1}{1-\beta}}\right) \\
& -\frac{\bar{Z}}{(1+A) w}\left(\frac{A}{(1-\alpha)}\left(\frac{p_{x} \alpha}{(1+r) w}\right)^{\frac{1}{1-\alpha}}+\frac{1}{(1-\beta)}\left(\frac{p_{y} \beta}{(1+r) w}\right)^{\frac{1}{1-\beta}}\right)
\end{aligned}
$$

If $\alpha>\beta$ and $\frac{p_{x}}{p_{y}}>\frac{\beta}{\alpha}$ then $\frac{d\left(L_{x}^{*}\left(p_{x}, p_{y}, w, r, \bar{Z}\right)+L_{y}^{*}\left(p_{x}, p_{y}, w, r, \bar{Z}\right)\right.}{d w}<0$

If those conditions hold, total labor demand on the farm decreases in $\mathrm{w}$ at all values of the independent variables (for other cases it is not trivial to show that).

\section{3.) Reaction of cotton production to an increase in $p_{x}$ for the representative farm:}

$$
\frac{d X^{*}\left(p_{x}, p_{y}, w, r, \bar{Z}\right)}{d p_{x}}=\frac{A \bar{Z}}{1+A}\left(\frac{p_{x} \alpha}{(1+r) w}\right)^{\frac{\alpha}{1-\alpha}} \frac{1}{(1-\alpha) p_{x}}\left(\alpha+\frac{1}{1+A}\right)>0
$$

Elasticity of cotton production with respect to a change in px:

$$
\varepsilon_{X^{*}}\left(p_{x}, p_{y}, w, r, \bar{z}\right), p_{x}=\frac{1}{(1-\alpha)}\left(\alpha+\frac{1}{1+A}\right)>0
$$

\section{2.) The ginnery as an intermediate monopsonistic trader}

Because the production decisions on both farm types are well described by the representative farm, one can assume that the ginnery with a local monopsony for the region $\mathrm{R}$ faces the supply of raw cotton from a representative farm with the endowment of cultivatable land $\bar{Z}_{R}$ in the region R.

From the interviews, we know that private dehkan and collective farms face the same output prices for raw cotton. There is no price discrimination between private dehkan and collective farms. Thus, we can model the supply of raw cotton in the region $\mathrm{R}$ assuming a representative farm with endowment of land $\bar{Z}_{R}$.

In this model, we assume that the ginnery only has monopsony power in the market for raw cotton (due to transport costs and pressure from local politicians and elites). This assumption is supported by our interview results. After reforms in 2007/2008, gins have less monopoly power in the markets for credit and for inputs. Farmers can get inputs and credit from other sources (like microfinance institutions and banks, other retail input suppliers). Gins finance their operations with credit from national banks and are price takers regarding the interest rate $r^{40}$

Total supply of raw cotton in the region R:

\footnotetext{
${ }^{40}$ However, one could add monopoly power for credit and input markets in the profit maximization of the ginnery and investigate the reaction of optimal interest rates, the optimal amount of credit given out to farms and optimal input prices of the monopoly to a change in the world price of cotton.
} 


$$
X_{R}^{*}\left(p_{x}, p_{y}, w, r, \bar{Z}_{R}\right)=\left(\frac{p_{x} \alpha}{(1+r) w}\right)^{\frac{\alpha}{1-\alpha}} \frac{A \bar{Z}_{R}}{1+A}
$$

\section{Profit maximization of the ginnery:}

The ginnery buys raw cotton $X_{R}^{*}$ and has to gin this cotton to get $\theta X_{R}^{*}$ ginned cotton which it can sell on the world market for price $p_{w}$. In Tajikistan, the efficiency parameter $\theta$ is typically around 0.3 (see Kassam, 2011). The gin pays $p_{x}$ for the raw cotton it purchases from farmers. There is no price discrimination between farm types.

$$
\pi_{g}=p_{w} \theta X_{R}^{*}\left(p_{x}, p_{y}, w, r, \bar{Z}_{R}\right)-p_{x} X_{R}^{*}\left(p_{x}, p_{y}, w, r, \bar{Z}_{R}\right)
$$

Maximazation w.r.t. $p_{x}$ gives:

$$
p_{x}^{*}=\frac{p_{w} \theta \varepsilon_{X_{R}^{*}}\left(p_{x}, p_{y}, w, r, \bar{Z}_{R}\right), p_{x}}{1+\varepsilon_{X_{R}^{*}}\left(p_{x}, p_{y}, w, r, \bar{Z}_{R}\right), p_{x}}
$$

Where: $\varepsilon_{X_{R}^{*}}\left(p_{x}, p_{y}, w, r, \bar{Z}_{R}\right), p_{x}=\frac{1}{(1-\alpha)}\left(\alpha+\frac{1}{1+A}\right)$

2.1.) Fixed degree of market power (supply elasticity $\varepsilon_{X_{R}^{*}}\left(p_{x}, p_{y}, w, r, \bar{Z}_{R}\right), p_{x}$ is constant):

$$
\frac{d p_{x}^{*}\left(p_{y}, w, r, \bar{Z}_{R}, p_{w}\right)}{d p_{w}}=\frac{\theta \varepsilon_{X_{R}^{*}\left(p_{x}, p_{y}, w, r, \bar{Z}_{R}\right), p_{x}}}{1+\varepsilon_{X_{R}^{*}\left(p_{x}, p_{y}, w, r, \bar{Z}_{R}\right), p_{x}}}
$$

Then it is trivial to see that $\varepsilon_{p_{x}^{*}}\left(p_{y}, w, r, \bar{Z}_{R}, p_{w}\right), p_{w}=1$

A $100 \%$ increase in the world market price would lead to a $100 \%$ increase in the farm gate price.

2.2.) Solution with flexible supply elasticity $\varepsilon_{X_{R}^{*}}\left(p_{x}, p_{y}, w, r, \bar{Z}_{R}\right), p_{x}$

Defining:

$$
\begin{gathered}
A=B p_{x}^{\frac{1}{1-\alpha}} \\
B=\frac{(1-\alpha) \alpha^{\frac{\alpha}{1-\alpha}}}{(1-\beta) p_{y}^{\frac{1}{1-\beta}} \beta^{\frac{\beta}{1-\beta}}}(w(1+r))^{\frac{\beta}{1-\beta}-\frac{\alpha}{1-\alpha}}
\end{gathered}
$$

Simple algebra leads to the following first order condition for $p_{x}^{*}\left(p_{y}, w, r, \bar{Z}_{R}, p_{w}\right)$ :

$$
2 p_{x}^{*}+B p_{x}^{*} \frac{1}{1-\alpha}\left(p_{x}^{*}-p_{w} \theta \alpha\right)=p_{w} \theta(\alpha+1)
$$

An explicit solution for $p_{x}^{*}$ does not exist. Applying the implicit function theorem: 


$$
\frac{d p_{x}^{*}\left(p_{y}, w, r, \bar{Z}_{R}, p_{w}\right)}{d p_{w}}=\frac{\theta \alpha B p_{x}^{*} \frac{1}{1-\alpha}+\theta(\alpha+1)}{2+\frac{B p_{x}^{*} \frac{1}{1-\alpha}}{1-\alpha}\left(2-\alpha-\frac{p_{w} \theta \alpha}{p_{x}^{*}}\right)}
$$

The numerator is always positive.

1.) The denominator and thus $\frac{d p_{x}^{*}\left(p_{y}, w, r, \bar{Z}_{R}, p_{w}\right)}{d p_{w}}$ is positive, if $\frac{2-\alpha}{\alpha}>\frac{p_{w} \theta}{p_{x}^{*}}$ (which should be the case for reasonable values of $\alpha$ )

2.) If $\frac{2-\alpha}{\alpha}<\frac{p_{w} \theta}{p_{x}^{*}}$ the denominator and thus $\frac{d p_{x}^{*}\left(p_{y}, w, r, \bar{Z}_{R}, p_{w}\right)}{d p_{w}}$ is positive, if $\frac{B p_{x}^{*} \frac{1}{1-\alpha}}{1-\alpha}\left(2-\alpha-\frac{p_{w} \theta \alpha}{p_{x}^{*}}\right)>-2$

Thus, for reasonable values of the model parameters, the monopsonistic ginnery would always increase the farm gate price for raw cotton in reaction to an increase in the world market price for ginned cotton.

\section{3.) Partial equilibrium in local labor markets}

Due to extensive labor migration of male to Russia as well as the civil war in the 1990s, the agricultural labor force in rural areas of Tajikistan comprises mostly female workers (FAO 2009, 2011). Because of strong traditional norms and the Islamic revival, those female agricultural workers are not mobile across sub-districts. That is why rural labor markets in Tajikistan are best described as local labor markets that are defined by villages and their neighboring communities (see Interviews in March and November 2014). For simplicity reasons, we will assume that the region R the gin faces as a monopoly equals the area of the local labor market. This assumption is realistic, because most subdistricts in Tajikistan are controlled by one ginnery.

Because production on both farm types is well described by the representative farm, one can assume that the supply of raw cotton in region $\mathrm{R}$ can be described by a representative farm with endowment of land $\bar{Z}_{R}$ in the region $\mathrm{R}$.

$$
X_{R}^{*}\left(p_{x}, p_{y}, w, r, \bar{Z}_{R}\right)=\left(\frac{p_{x} \alpha}{(1+r) w}\right)^{\frac{\alpha}{1-\alpha}} \frac{A \bar{Z}_{R}}{1+A}
$$

Total labor demand in the region $\mathrm{R}$ is:

$$
L_{\text {Total Demand }, R}^{*}\left(p_{x}, p_{y}, w, r, \bar{Z}_{R}\right)=\frac{\bar{Z}_{R}}{1+A}\left(\left(\frac{p_{x} \alpha}{(1+r) w}\right)^{\frac{1}{1-\alpha}} A+\left(\frac{p_{y} \beta}{(1+r) w}\right)^{\frac{1}{1-\beta}}\right)
$$

Total labor demand in region $\mathrm{R}$ decreases with rising wage $\mathrm{w}$, if $\alpha>\beta$ and $\frac{p_{x}}{p_{y}}>\frac{\beta}{\alpha}$ : 


$$
\begin{aligned}
& \frac{d\left(L_{\text {Total Demand }, R}^{*}\left(p_{x}, p_{y}, w, r, \bar{Z}_{R}\right)\right)}{d w} \\
& =\frac{A \bar{Z}_{R}}{(1+A) w}\left(\frac{\left.\frac{\beta}{1-\beta}-\frac{\alpha}{1-\alpha}\right)\left(\left(\frac{p_{x} \alpha}{1+A}\right){ }^{\frac{1}{1-\alpha}}-\left(\frac{p_{y} \beta}{(1+r) w}\right)^{\frac{1}{1-\beta}}\right)}{}\right. \\
& -\frac{\bar{Z}_{R}}{(1+A) w}\left(\frac{A}{(1-\alpha)}\left(\frac{p_{x} \alpha}{(1+r) w}\right)^{\frac{1}{1-\alpha}}+\frac{1}{(1-\beta)}\left(\frac{p_{y} \beta}{(1+r) w}\right)^{\frac{1}{1-\beta}}\right)<0
\end{aligned}
$$

\section{Now solve for the partial equilibrium in the local labor market:}

The important difference between private dehkan and collective farms is that both farm types face different local labor supplies. Small private dehkan farms face a competitive local labor market that comprises landless females from local villages whose male family members have migrated to Russia for work. In the harvest time, private dehkan farms in local labor markets compete for those female agricultural workers. In contrast, large collective farms are still heavily intertwined with local governments and receive harvest workers sent by the local government. Those workers are employed in the public administration, schools, hospitals and other para-statal enterprises and are forced to work at the cotton harvest for minimum picking wages. ${ }^{41}$ For further details please see the Appendix on the qualitative interviews in Tajikistan.

We define $\overline{Z_{R, P F}}$ as the land under private dehkan farms (PF) in region $\mathrm{R}$ and $\overline{Z_{R, C F}}$ as the land under collective farms $(C F)$ in region R. From $\operatorname{Kassam}(2011)$ and FAO $(2009,2011)$ we know that the share of cultivated land under collective farms and state owned enterprises, which have similar organizational structures than collective farms, is about $40 \%$ for the whole Republic of Tajikistan.

$$
\overline{Z_{R, P F}}+\overline{Z_{R, C F}}=\bar{Z}_{R}
$$

\section{1.) Partial equilibrium for small private dehkan farms}

Private dehkan farms face a efficiency wage curve, the elasticity of labor supply w.r.t. the wage is positive $(\gamma>0)$. Those farms have to increase wages to attract further picking workers from local village labor markets. Workers from local villages have a reservation wage that mainly depends on household remittances and the level of subsistence production on household plots.

$$
L_{S, P F}(w)=\gamma w-k
$$

Where $\mathrm{k}>0$ and the reservation wage $w_{r}=\frac{k}{\gamma}$

\section{Local labor market partial equilibrium:}

$$
L_{\text {Total Demand }, R, P F}^{*}\left(p_{x}, p_{y}, w^{*}, r, \overline{Z_{R, P F}}\right)=L_{S, P F}\left(w^{*}\right)
$$

Leads to:

\footnotetext{
${ }^{41}$ Members of large collective farms comprise the other part of the coerced labor pool that large farms are able to tap. Those members (mostly female) are bound to the large farm by strong social and traditional norms, a lack of human capital and financial resources as well as missing conscience about freedom to farm and their rights.
} 


$$
0=\frac{\bar{Z}_{R, P F}}{1+A}\left(\left(\frac{p_{x} \alpha}{(1+r) w}\right)^{\frac{1}{1-\alpha}} A+\left(\frac{p_{y} \beta}{(1+r) w}\right)^{\frac{1}{1-\beta}}\right)-\gamma w^{*}+k
$$

An explicit solution for $\mathrm{w}$ does not exist. Applying the implicit function theorem leads to:

$$
\begin{aligned}
& \frac{d w^{*}\left(p_{x}, p_{y}, w^{*}, r, \overline{Z_{R, P F}}\right)}{d p_{x}}=-\frac{E}{F} \\
& E=\frac{A \overline{Z_{R, P F}}}{(1+A)} \frac{1}{(1-\alpha) p_{x}}\left(\left(\frac{p_{x} \alpha}{(1+r) w}\right)^{\frac{1}{1-\alpha}}\left(\frac{2+A}{1+A}\right)-\left(\frac{p_{y} \beta}{(1+r) w}\right)^{\frac{1}{1-\beta}}\left(\frac{1}{1+A}\right)\right) \\
& F=\frac{A \bar{Z}_{R}}{(1+A) w}\left(\frac{\left.\frac{\beta}{1-\beta}-\frac{\alpha}{1-\alpha}\right)\left(\left(\frac{p_{x} \alpha}{(1+r) w}\right)^{\frac{1}{1-\alpha}}-\left(\frac{p_{y} \beta}{(1+r) w}\right)^{\frac{1}{1-\beta}}\right)}{-\frac{\bar{Z}_{R}}{(1+A) w}\left(\frac{A}{(1-\alpha)}\left(\frac{p_{x} \alpha}{(1+r) w}\right)^{\frac{1}{1-\alpha}}+\frac{1}{(1-\beta)}\left(\frac{p_{y} \beta}{(1+r) w}\right)^{\frac{1}{1-\beta}}\right)-\gamma<0}\right.
\end{aligned}
$$

If $\alpha>\beta$ and $\frac{p_{x}}{p_{y}}>\frac{\beta}{\alpha}$ the denominator $\mathrm{F}$ is negative. Other cases are not trivial to solve.

If $\alpha>\beta$ and $\frac{p_{x}}{p_{y}}>\frac{\beta}{\alpha}$ the nominator is positive (total labor demand on private dehkan farms increases in $\mathrm{p}_{\mathrm{x}}$; for other cases it is not trivial to show that).

Thus for $\alpha>\beta$ and $\frac{p_{x}}{p_{y}}>\frac{\beta}{\alpha}$ it follows that:

$\frac{d w^{*}\left(p_{x}, p_{y}, w^{*}, r, \overline{Z_{R, P F}}\right)}{d p_{x}}>0$

For reasonable values of the model parameters, the wages on small private dehkan farms increase if the farm gate price for raw cotton increases (cet. par.).

\section{2.) Partial equilibrium for collective farms and state owned agricultural enterprises}

Collective farms face an infinitely elastic labor supply due to political connections and coerced labor. Managers of the collective farms can dispose of a pool of coerced labor and do not have to raise wages to increase labor supply. They pay the minimum picking wage $(\bar{w})$ that is announced by the district government (hukumat) each year before the cotton harvest starts.

Labor supply for collective farms is completely elastic until a certain maximum amount:

$$
L_{S, C F}=\bar{L}_{C F}
$$

\section{Local labor market partial equilibrium:}

$$
L_{\text {Total Demand }, R, C F}^{*}\left(p_{x}, p_{y}, \bar{w}, r, \overline{Z_{R, C F}}\right)=L_{S, C F}
$$


Leads to:

$$
0=\frac{\bar{Z}_{R, C F}}{1+A}\left(\left(\frac{p_{x} \alpha}{(1+r) \bar{w}}\right)^{\frac{1}{1-\alpha}} A+\left(\frac{p_{y} \beta}{(1+r) \bar{w}}\right)^{\frac{1}{1-\beta}}\right)-\bar{L}_{C F}
$$

Thus, increasing labor demand on collective farms is met by the respective labor supply at the minimum picking wage $(\bar{w})$ until labor demand reaches the value $\bar{L}_{C F}$. At this point, the pool of coerced labor is exhausted and collective farms cannot further increase labor demand and cotton production. An increase in the farm gate price of cotton $\mathrm{p}_{\mathrm{x}}$ would lead to increased cotton production on collective farms until the pool of coerced labor is exhausted, but wages for picking workers on collective farms would stay constant.

From the evaluation of the interviews, we know that collective farms always paid the minimum picking wage announced by the hukumat. Those farms did not participate in local labor markets to attract further workers by rising picking wages. In most cases, collective farms did not exhaust the pool of coerced labor and were able to match their labor demand with sufficient picking workers. However, in many cases the cotton harvest at collective farms lasted longer and some collective farms seemed to have problems in meeting their picking labor demand. Statistics on cotton production and area under cotton for small vs. large farms show that in some districts large collective farms did increase cotton area and production not as strongly as the small private dehkan farms in 2011 (Table). This might be partly explained by the labor supply restrictions for collective farms in those districts. 


\section{Appendix D: List of Interviews conducted in Tajikistan between January and November 2014}

\begin{tabular}{|c|c|c|c|}
\hline $\begin{array}{l}\text { Interview } \\
\text { Number }\end{array}$ & Date, Time & Location & Interview Partners \\
\hline 1. & $\begin{array}{l}5 \text { March 2014, } \\
11 \text { am }\end{array}$ & $\begin{array}{l}\text { National Academy of } \\
\text { Sciences, Dushanbe }\end{array}$ & $\begin{array}{l}\text { Prof. Dr. Mustafar Olimov, Director Research } \\
\text { Institute SHARQ }\end{array}$ \\
\hline 2. & $\begin{array}{l}5 \text { March 2014, } \\
3 \text { pm }\end{array}$ & $\begin{array}{l}\text { Office of the German } \\
\text { Federal Enterprise for } \\
\text { International Cooperation } \\
\text { (GIZ), Dushanbe }\end{array}$ & $\begin{array}{l}\text { Muhammadi Muminow, Director of the } \\
\text { agricultural consultancy firm SAROB that is } \\
\text { supported and funded by the GIZ Tajikistan }\end{array}$ \\
\hline 3. & $\begin{array}{l}6 \text { March 2014, } \\
2 \mathrm{pm}\end{array}$ & GIZ Office, Dushanbe & $\begin{array}{l}\text { Hartwig Ungethuem, Team Leader of the GIZ } \\
\text { Divisions "Business Enabling Environment" } \\
\text { und "Value Chains", GIZ Tajikistan }\end{array}$ \\
\hline 4. & $\begin{array}{l}12 \quad \text { March } \\
2014,11 \mathrm{am}\end{array}$ & Restaurant, Dushanbe & $\begin{array}{l}\text { Staff member of the Ministry of Agriculture of } \\
\text { the Republic of Tajikistan and owner of a } \\
\text { family farm in Hissar district; another colleague } \\
\text { of him that also owns a family farm in Hissar } \\
\text { district (both requested anonymous citation) }\end{array}$ \\
\hline 5. & $\begin{array}{l}12 \quad \text { March } \\
2014,1.30 \mathrm{pm}\end{array}$ & $\begin{array}{l}\text { Restaurant „Traktor“, } \\
\text { Dushanbe }\end{array}$ & $\begin{array}{l}\text { Staff members of the Tajik cotton trading } \\
\text { companies Eurotex Ventures Inc. and Golden } \\
\text { Lion LLC (business partners of the international } \\
\text { cotton trading company Reinhart AG) } \\
\text { (requested anonymous citation) }\end{array}$ \\
\hline 6. & $\begin{array}{l}12 \quad \text { March } \\
2014,5.30 \mathrm{pm}\end{array}$ & $\begin{array}{l}\text { Café of the National Library } \\
\text { of Tajikistan, Dushanbe }\end{array}$ & $\begin{array}{l}\text { Dr. Hafiz Boboyorov, Research Associate at the } \\
\text { National Academy of Sciences of Tajikistan } \\
\text { and Research Fellow of the German research } \\
\text { institute "Zentrum für Entwicklungsforschung } \\
\text { (ZEF)" in Bonn, expert for social and political } \\
\text { power structures in cotton areas of Tajikistan }\end{array}$ \\
\hline 7. & $\begin{array}{l}13 \quad \text { March } \\
2014,9 \mathrm{am}\end{array}$ & $\begin{array}{l}\text { Hissar district }(\mathrm{RRP} \\
\text { province), courtyard of the } \\
\text { large collective farm }\end{array}$ & $\begin{array}{l}\text { Two workers of a large collective farm (1500 } \\
\text { ha), one driver and another worker }\end{array}$ \\
\hline 8. & $\begin{array}{l}13 \quad \text { March } \\
2014,10 \text { am }\end{array}$ & $\begin{array}{l}\text { Hissar district, courtyard of } \\
\text { the large collective farm }\end{array}$ & $\begin{array}{l}\text { Vice-Manager of the same large collective farm } \\
\text { (from interview } 7 \text { ), the agronomist of the farm }\end{array}$ \\
\hline 9. & $\begin{array}{l}13 \quad \text { March } \\
2014,2 \mathrm{pm}\end{array}$ & $\begin{array}{l}\text { Hissar district, fields of the } \\
\text { farm }\end{array}$ & $\begin{array}{l}\text { Manager of a collective farm }\left(\begin{array}{ll}59 & \text { ha }\end{array}\right) \text {, } \\
\text { Agronomist for Hissar district at the agricultural } \\
\text { consultancy firm SAROB }\end{array}$ \\
\hline 10. & $\begin{array}{l}13 \quad \text { March } \\
2014,3 \mathrm{pm}\end{array}$ & $\begin{array}{l}\text { Hissar district, fields of the } \\
\text { farm }\end{array}$ & Manager of a collective farm (128 ha) \\
\hline 11. & $\begin{array}{l}14 \quad \text { March } \\
2014,9 \mathrm{am}\end{array}$ & $\begin{array}{l}\text { Hissar district, courtyard of } \\
\text { the large collective farm }\end{array}$ & Director of a large collective farm (605 ha) \\
\hline 12. & $\begin{array}{l}14 \quad \text { March } \\
2014,11 \text { am }\end{array}$ & $\begin{array}{l}\text { Sharinav district (RRP } \\
\text { province), fields of the farm }\end{array}$ & $\begin{array}{l}\text { Farm head and one worker of a family dehkan } \\
\text { farm ( } 2 \text { ha) }\end{array}$ \\
\hline 13. & $\begin{array}{l}14 \quad \text { March } \\
2014,12 \mathrm{pm}\end{array}$ & $\begin{array}{l}\text { Sharinav district, fields of } \\
\text { the farm }\end{array}$ & Farm head of a family dehkan farm $(3,2 \mathrm{ha})$ \\
\hline 14. & $\begin{array}{ll}14 & \text { March } \\
2014,1 \mathrm{pm}\end{array}$ & $\begin{array}{l}\text { Sharinav district, fields of } \\
\text { the farm }\end{array}$ & Farm head of a family dehkan farm (2 ha) \\
\hline 15 . & $\begin{array}{l}14 \quad \text { March } \\
2014,3 \mathrm{pm}\end{array}$ & GIZ Office, Dushanbe & $\begin{array}{l}\text { Sanginboy Sanginow, former staff member of } \\
\text { the Food and Agricultural Organization (FAO) } \\
\text { in Tajikistan, senior expert on the agricultural } \\
\text { sector in Tajikistan }\end{array}$ \\
\hline 16. & $\begin{array}{l}17 \quad \text { March } \\
2014,2 \mathrm{pm}\end{array}$ & $\begin{array}{l}\text { Kurgonteppa City (Khatlon } \\
\text { province), hotel lobby }\end{array}$ & $\begin{array}{l}\text { Leading Agronomist for three districts at the } \\
\text { agricultural consultancy firm SAROB (Firuz) } \\
\text { and another agronomist }\end{array}$ \\
\hline 17. & $\begin{array}{l}17 \quad \text { March } \\
2014,3 \mathrm{pm}\end{array}$ & $\begin{array}{l}\text { Bohtar district (Khatlon } \\
\text { province), sub-district } \\
\text { Navbahor, courtyard of the } \\
\text { collective farm }\end{array}$ & Manager of a collective farm (230 ha) \\
\hline 18. & March & Bohtar district, sub-district & Manager of the cotton ginnery and of a \\
\hline
\end{tabular}




\begin{tabular}{|c|c|c|c|}
\hline & $2014,4.30 \mathrm{pm}$ & $\begin{array}{l}\text { Navbahor, office of the } \\
\text { cotton ginnery }\end{array}$ & collective farm (120 ha) \\
\hline 19. & $\begin{array}{l}17 \quad \text { March } \\
2014,6 \mathrm{pm}\end{array}$ & $\begin{array}{l}\text { Bohtar district, sub-district } \\
\text { Navbahor, courtyard of the } \\
\text { farm }\end{array}$ & Farm head of a family dehkan farm (10 ha) \\
\hline 20. & $\begin{array}{lr}18 & \text { March } \\
2014, & 10.30 \\
\text { am } & \\
\end{array}$ & $\begin{array}{l}\text { Bohtar district, sub-district } \\
\text { Sargar, house of the family }\end{array}$ & Farm head of a family dehkan farm $(7,5 \mathrm{ha})$ \\
\hline 21. & $\begin{array}{l}18 \quad \text { March } \\
2014,12 \mathrm{pm}\end{array}$ & $\begin{array}{l}\text { Bohtar district, sub-district } \\
\text { Sargar, hospital of the sub- } \\
\text { district }\end{array}$ & $\begin{array}{l}\text { Former futurist and cotton trader and now } \\
\text { manager of a collective farm (106 ha), } \\
\text { agronomist of the collective farm and also farm } \\
\text { head of a family dehkan farm ( } 5 \text { ha) }\end{array}$ \\
\hline 22. & $\begin{array}{l}18 \text { March } \\
2014,2 \mathrm{pm}\end{array}$ & $\begin{array}{l}\text { Bohtar district, sub-district } \\
\text { Sargar, hospital of the sub- } \\
\text { district }\end{array}$ & $\begin{array}{l}\text { Worker of the collective farm (from Interview } \\
21 \text { ) }\end{array}$ \\
\hline 23. & $\begin{array}{l}18 \text { March } \\
2014,5 \mathrm{pm}\end{array}$ & $\begin{array}{l}\text { Kholkozobod } \begin{array}{r}\text { district } \\
\text { (Khatlon province), }\end{array} \\
\text { Kholkozobod city, house of } \\
\text { the family }\end{array}$ & $\begin{array}{l}\text { Former Minister of Agriculture of the Republic } \\
\text { of Tajikistan and now farm head of a family } \\
\text { dehkan farm (10 ha), district administration } \\
\text { official responsible for irrigation infrastructure }\end{array}$ \\
\hline 24. & $\begin{array}{l}19 \text { March } \\
2014,5 \mathrm{pm}\end{array}$ & $\begin{array}{l}\text { Vosé district } \begin{array}{l}\text { (Khatlon } \\
\text { province), } \\
\text { Miyali, house of the family }\end{array} \\
\end{array}$ & Manager of a collective farm (120 ha) \\
\hline 25. & $\begin{array}{l}20 \quad \text { March } \\
2014,10 \mathrm{am}\end{array}$ & $\begin{array}{l}\text { Vosé district, sub-district } \\
\text { Miyali, courtyard of the } \\
\text { farm }\end{array}$ & $\begin{array}{l}\text { Two workers of the collective farm (from } \\
\text { Interview 24) and the agronomist of the farm }\end{array}$ \\
\hline 26. & $\begin{array}{l}20 \quad \text { March } \\
2014,12 \mathrm{pm}\end{array}$ & $\begin{array}{l}\text { Vosé district, sub-district } \\
\text { Miyali, house of the family }\end{array}$ & Farm head of a family dehkc \\
\hline 27. & $\begin{array}{l}20 \quad \text { March } \\
2014,5 \mathrm{pm}\end{array}$ & $\begin{array}{l}\text { Moskovskaya district } \\
\text { (Khatlon province), fields of } \\
\text { the farm }\end{array}$ & Worker of a family dehkan far \\
\hline 28. & $\begin{array}{l}20 \quad \text { March } \\
2014,6 \mathrm{pm}\end{array}$ & $\begin{array}{l}\text { Moskovskaya district, fields } \\
\text { of the farm }\end{array}$ & $\begin{array}{l}\text { Farm head and worker of a family dehkan farm } \\
(8 \mathrm{ha})\end{array}$ \\
\hline 29. & $\begin{array}{l}27 \quad \text { March } \\
2014,9 \mathrm{am}\end{array}$ & $\begin{array}{l}\text { Kuhjand City } \text { (Sughd } \\
\text { province), office of the } \\
\text { agricultural consultancy } \\
\text { firm SAROB }\end{array}$ & $\begin{array}{l}\text { Director of the agricultural consultancy firm } \\
\text { SAROB for Sughd province }\end{array}$ \\
\hline 30. & $\begin{array}{l}27 \quad \text { March } \\
2014,3 \mathrm{pm}\end{array}$ & $\begin{array}{l}\text { Konibodom district (Sughd } \\
\text { province), sub-district } \\
\text { Selski Soviet, fields of the } \\
\text { farm }\end{array}$ & $\begin{array}{l}\text { Manager of a collective farm ( } 36 \text { ha }) \text { and } \\
\text { former head of a kolkhoze brigade }\end{array}$ \\
\hline 31. & $\begin{array}{l}27 \quad \text { March } \\
2014,4 \mathrm{pm}\end{array}$ & $\begin{array}{l}\text { Konibodom district, sub- } \\
\text { district Selski Soviet, fields } \\
\text { of the farm }\end{array}$ & $\begin{array}{l}\text { Ten workers of the collective farm (from } \\
\text { Interview 30) }\end{array}$ \\
\hline 32. & $\begin{array}{lr}27 & \text { March } \\
2014, & 5.30 \mathrm{pm}\end{array}$ & $\begin{array}{l}\text { Konibodom district, sub- } \\
\text { district Ortikof, house of the } \\
\text { family }\end{array}$ & $\begin{array}{l}\text { Leading Agronomist for Konibodom district at } \\
\text { the agricultural consultancy firm SAROB }\end{array}$ \\
\hline 33. & $\begin{array}{l}27 \quad \text { March } \\
2014,6 \mathrm{pm}\end{array}$ & $\begin{array}{l}\text { Konibodom district, sub- } \\
\text { district Ortikof, house of the } \\
\text { family }\end{array}$ & $\begin{array}{l}\text { Manager of a collective farm (74 ha), } \\
\text { agronomist of the collective farm and also farm } \\
\text { head of a family dehkan farm }(1,5 \mathrm{ha})\end{array}$ \\
\hline 34. & $\begin{array}{l}28 \quad \text { March } \\
2014,12 \mathrm{pm}\end{array}$ & $\begin{array}{l}\text { Mastchoh district (Sughd } \\
\text { province), house of the } \\
\text { family }\end{array}$ & $\begin{array}{l}\text { Leading Agronomist for Mastchoh district at } \\
\text { the agricultural consultancy firm SAROB and } \\
\text { also manager of a collective farm ( } 110 \mathrm{ha})\end{array}$ \\
\hline 35. & $\begin{array}{l}28 \text { March } \\
2014,3 \mathrm{pm}\end{array}$ & $\begin{array}{l}\text { Mastchoh district, house of } \\
\text { the family }\end{array}$ & $\begin{array}{l}\text { Farm head of a family dehkan farm ( } 5 \mathrm{ha}) \text { and } \\
\text { former manager of a collective farm }(80 \mathrm{ha})\end{array}$ \\
\hline 36. & $\begin{array}{l}28 \quad \text { March } \\
2014,5 \mathrm{pm}\end{array}$ & $\begin{array}{l}\text { Mastchoh district, house of } \\
\text { the family }\end{array}$ & Farm head of a family dehkan farm $(3,6 \mathrm{ha})$ \\
\hline 37. & $\begin{array}{l}29 \text { March } \\
2014,8 \mathrm{am}\end{array}$ & $\begin{array}{l}\text { Kuhjand City, Office of the } \\
\text { Deputy-Minister } r \text { of } \\
\text { Agriculture for Sughd } \\
\text { province, Tajikistan }\end{array}$ & $\begin{array}{l}\text { Deputy-Minister of Agriculture for Sughd } \\
\text { province, Tajikistan }\end{array}$ \\
\hline
\end{tabular}




\begin{tabular}{|c|c|c|c|}
\hline 38. & $\begin{array}{l}29 \quad \text { March } \\
2014,11 \mathrm{am}\end{array}$ & $\begin{array}{l}\text { Kuhjand City, office in the } \\
\text { Ministry of Agriculture for } \\
\text { Sughd province }\end{array}$ & $\begin{array}{l}\text { Leading Agronomist for Sughd province at the } \\
\text { agricultural consultancy firm SAROB and also } \\
\text { former Deputy-Minister of Agriculture for } \\
\text { Sughd province }\end{array}$ \\
\hline 39. & $\begin{array}{l}31 \quad \text { March } \\
2014,10 \text { am }\end{array}$ & $\begin{array}{l}\text { World Bank } \text { Office, } \\
\text { Dushanbe }\end{array}$ & $\begin{array}{l}\text { Bobojon Yatimov, staff member and cotton } \\
\text { sector expert, World Bank Tajikistan }\end{array}$ \\
\hline 40. & $\begin{array}{l}31 \quad \text { March } \\
2014,2 \mathrm{pm}\end{array}$ & GIZ Office, Dushanbe & $\begin{array}{l}\text { Torsten Swoboda, Agricultural Consultant at } \\
\text { the GIZ Divisions "Business Enabling } \\
\text { Environment" und "Value Chains", GIZ } \\
\text { Tajikistan }\end{array}$ \\
\hline 41. & $\begin{array}{l}1 \text { April 2014, } \\
9.30 \mathrm{am}\end{array}$ & $\begin{array}{l}\text { Statistics Institute of the } \\
\text { Republic of Tajikistan, } \\
\text { Dushanbe }\end{array}$ & Staff member of the Tajik Statistics Institute \\
\hline 42 & $\begin{array}{l}16 \text { April 2014, } \\
11 \text { am }\end{array}$ & $\begin{array}{l}\text { Skype phone call, office at } \\
\text { the University of Munich } \\
\text { (LMU) }\end{array}$ & $\begin{array}{l}\text { Former Country-Manager Tajikistan of the } \\
\text { cotton trading company ECOM Agroindustrial } \\
\text { Corp. Ltd (requested anonymous citation) }\end{array}$ \\
\hline 43 & $\begin{array}{l}22 \text { January } \\
2014,4 \mathrm{pm}\end{array}$ & $\begin{array}{l}\text { Skype phone call, office at } \\
\text { the University of Munich } \\
\text { (LMU) }\end{array}$ & $\begin{array}{l}\text { Former Central-Asia-Manager for the cotton } \\
\text { trading company Reinhart AG (requested } \\
\text { anonymous citation) }\end{array}$ \\
\hline 44 & $\begin{array}{l}14 \quad \text { January } \\
2014,11 \text { am }\end{array}$ & $\begin{array}{l}\text { Skype phone call, office at } \\
\text { the University of Munich } \\
\text { (LMU) }\end{array}$ & $\begin{array}{l}\text { Dr. Andreas Mandler, researcher at the research } \\
\text { institute „Zentrum für Entwicklungsforschung } \\
\text { (ZEF)“ in Bonn and expert on political power } \\
\text { structures in rural areas of Tajikistan }\end{array}$ \\
\hline 45 & $\begin{array}{l}1 \text { April 2014, } \\
12 \mathrm{pm}\end{array}$ & GIZ Office, Dushanbe & $\begin{array}{l}\text { Zarina Kosymova, Deputy Team Leader, Head } \\
\text { of "Business Enabling Environment", GIZ } \\
\text { Tajikistan }\end{array}$ \\
\hline
\end{tabular}

\begin{tabular}{|c|c|c|c|}
\hline \multicolumn{4}{|c|}{ Overview of interviews conducted in Tajikistan in November 2014} \\
\hline 46. & $\begin{array}{l}11 \text { November } \\
2014,2 \mathrm{pm}\end{array}$ & GIZ Office, Dushanbe & $\begin{array}{l}\text { Igor Eromenko, Ph.D., Head of GIZ Division } \\
\text { "Evidence based decision making", GIZ } \\
\text { Tajikistan }\end{array}$ \\
\hline 47. & $\begin{array}{l}11 \text { November } \\
2014,4 \mathrm{pm}\end{array}$ & GIZ Office, Dushanbe & $\begin{array}{l}\text { Hartwig Ungethuem, Team Leader of the GIZ } \\
\text { Divisions "Business Enabling Environment" } \\
\text { and "Value Chains", GIZ Tajikistan }\end{array}$ \\
\hline 48. & $\begin{array}{l}18 \text { November } \\
2014,11 \mathrm{am}\end{array}$ & $\begin{array}{l}\text { Ministry of Agriculture of } \\
\text { the Republic of Tajikistan, } \\
\text { Dushanbe }\end{array}$ & $\begin{array}{l}\text { Head of Program "Information } \\
\text { Development in Agriculture Sector", Ministry } \\
\text { of Agriculture, Tajikistan } \\
\text { anonymous citation) }\end{array}$ \\
\hline 49. & $\begin{array}{l}19 \text { November } \\
2014,8 \text { am }\end{array}$ & $\begin{array}{l}\text { FAO Office within in the } \\
\text { Ministry of Agriculture of } \\
\text { the Republic of Tajikistan, } \\
\text { Dushanbe }\end{array}$ & $\begin{array}{l}\text { Staff member of the Office of the Food and } \\
\text { Agricultural Organization (FAO) in Tajikistan } \\
\text { (requested anonymous citation) }\end{array}$ \\
\hline 50. & $\begin{array}{l}19 \text { November } \\
2014,1.30 \mathrm{pm}\end{array}$ & $\begin{array}{l}\text { Café on Rudaki Street, } \\
\text { Dushanbe }\end{array}$ & $\begin{array}{l}\text { Former staff member of the ADB team that } \\
\text { planned and accompanied the Agricultural } \\
\text { Reforms in Tajikistan from 2005-2008 } \\
\text { (requested anonymous citation) }\end{array}$ \\
\hline 51. & $\begin{array}{l}20 \text { November } \\
2014,2 \mathrm{pm}\end{array}$ & $\begin{array}{l}\text { Office of the agricultural } \\
\text { finance consultancy firm, } \\
\text { Dushanbe }\end{array}$ & $\begin{array}{l}\text { Head of an agricultural finance consultancy } \\
\text { firm and former staff member of the EBRD } \\
\text { project Tajik Agricultural Finance Framework } \\
\text { (TAFF) (requested anonymous citation) }\end{array}$ \\
\hline 52. & $\begin{array}{l}20 \text { November } \\
2014,5 \mathrm{pm}\end{array}$ & GIZ Office, Dushanbe & $\begin{array}{l}\text { Torsten Swoboda, Agricultural Consultant at } \\
\text { the GIZ Divisions "Business Enabling } \\
\text { Environment" und "Value Chains", GIZ } \\
\text { Tajikistan; Igor Eromenko (Interview 46) }\end{array}$ \\
\hline 53. & $\begin{array}{l}27 \text { November } \\
2014,5 \mathrm{pm}\end{array}$ & GIZ Office, Dushanbe & $\begin{array}{l}\text { Zara Makhmudova, National Coordinator GIZ } \\
\text { Tajikistan and former National Coordinator of } \\
\text { the Tajik Farm Restructuring Project of the } \\
\text { World Bank, IMF and the Tajik Government }\end{array}$ \\
\hline 54. & $\begin{array}{l}28 \text { November } \\
2014,2 \mathrm{pm}\end{array}$ & $\begin{array}{l}\text { World Bank } \\
\text { Dushanbe }\end{array}$ & $\begin{array}{l}\text { Bobojon Yatimov, staff member and cotton } \\
\text { sector expert, World Bank Tajikistan }\end{array}$ \\
\hline
\end{tabular}




\begin{tabular}{|c|c|c|c|}
\hline 55 & $\begin{array}{l}13 \text { November } \\
2014,6 \mathrm{pm}\end{array}$ & GIZ Office, Dushanbe & $\begin{array}{l}\text { Shahlo Rahimova, Programme Manager, } \\
\text { DFID Central Asia }\end{array}$ \\
\hline 56 & $\begin{array}{l}7 \quad \text { October } \\
2014,10 \mathrm{am}\end{array}$ & Café, Munich, Germany & $\begin{array}{l}\text { Paul Frijters, Professor of Economics at the } \\
\text { University of Queensland, Researcher on } \\
\text { Political Economy in Tajikistan }\end{array}$ \\
\hline 57. & $\begin{array}{l}10 \quad \text { February } \\
2015,10 \text { am }\end{array}$ & $\begin{array}{l}\text { Phone call, office at the } \\
\text { University of Munich } \\
\text { (LMU) }\end{array}$ & 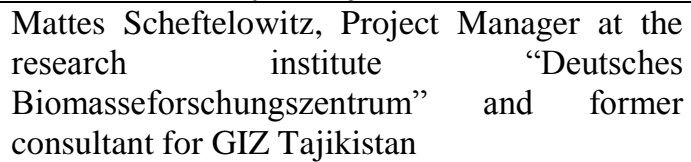 \\
\hline
\end{tabular}

